Report of Investigations 2012-2

Version 1.1

\title{
COASTAL HAZARD FIELD INVESTIGATIONS IN RESPONSE TO THE NOVEMBER 2011 BERING SEA STORM, NORTON SOUND, ALASKA
}

by

Nicole E.M. Kinsman and Meagan R. DeRaps

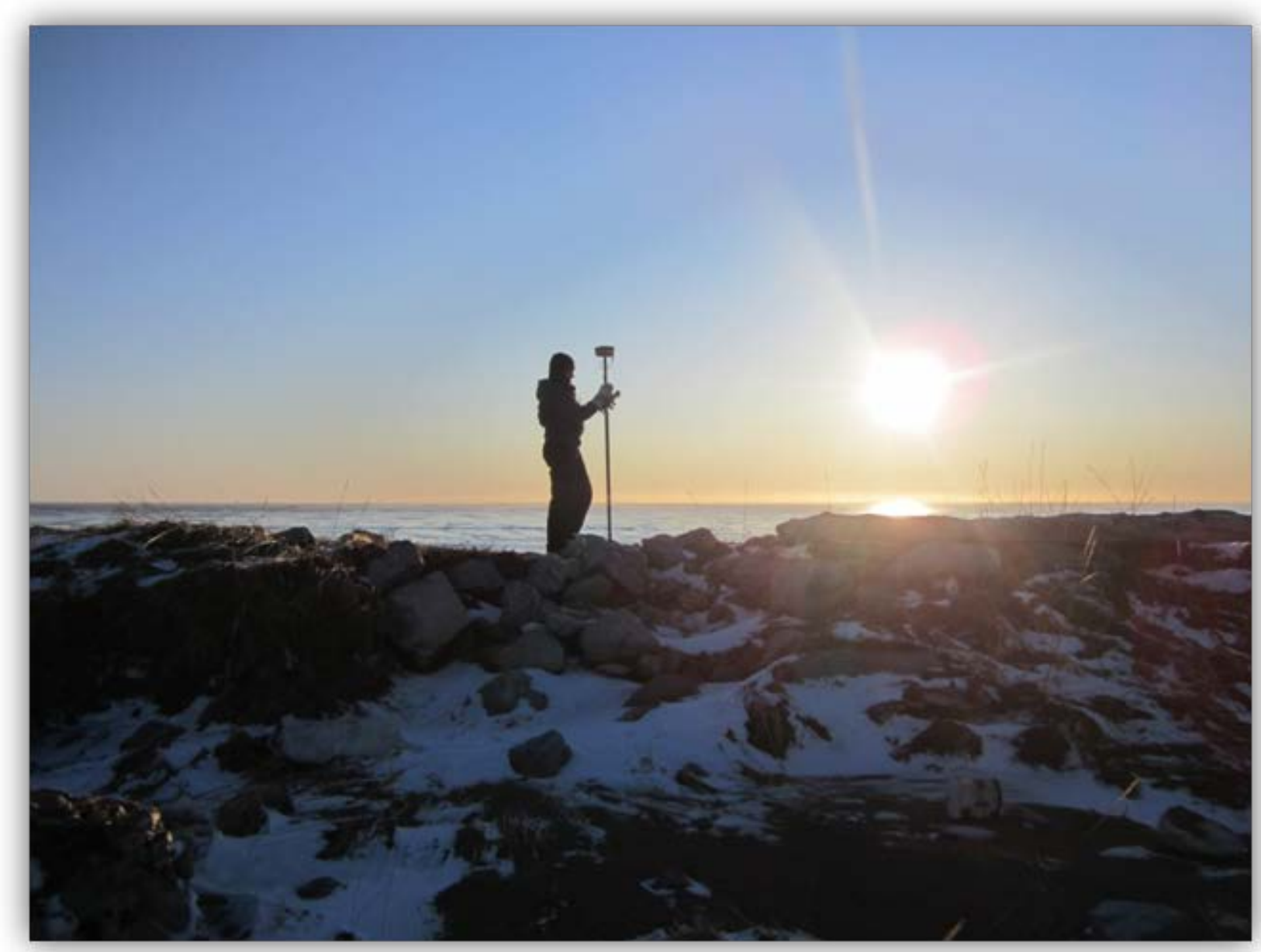

Published by

STATE OF ALASKA

DEPARTMENT OF NATURAL RESOURCES

DIVISION OF GEOLOGICAL \& GEOPHYSICAL SURVEYS

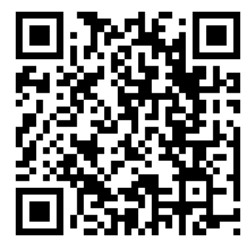




\section{Report of Investigations 2012-2 \\ Version 1.1}

\section{COASTAL HAZARD FIELD INVESTIGATIONS \\ IN RESPONSE TO THE NOVEMBER 2011 BERING SEA STORM, NORTON SOUND, ALASKA}

by

N.E.M. Kinsman and M.R. DeRaps

This publication is funded with qualified outer continental shelf oil and gas revenues by the Coastal Impact Assistance Program, U.S. Fish \& Wildlife Service, U.S. Department of the Interior. The views and conclusions contained in this document are those of the authors and should not be interpreted as representing the opinions or poli-cies of the U.S. Government. Mention of trade names or commercial products does not constitute their endorsement by the U.S. Government.

COVER PHOTO: DGGS geologist Meagan DeRaps measures the crest elevation of a minor blowout in a rock revetment along the Nome-Council Road. The blowout occurred during the November 2011 Bering Sea Storm. 


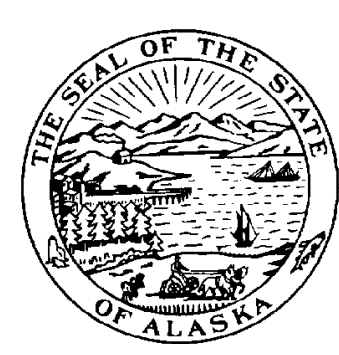

STATE OF ALASKA

Sean Parnell, Governor

DEPARTMENT OF NATURAL RESOURCES

Daniel S. Sullivan Commissioner

\title{
DIVISION OF GEOLOGICAL \& GEOPHYSICAL SURVEYS Robert F. Swenson, State Geologist and Director
}

Publications produced by the Division of Geological \& Geophysical Surveys (DGGS) are available for free download from the DGGS website (www.dggs.alaska.gov ). Publications on hard-copy or digital media can be examined or purchased in the Fairbanks office:

\author{
Alaska Division of Geological \& Geophysical Surveys \\ 3354 College Rd., Fairbanks, Alaska 99709-3707 \\ Phone: (907) 451-5020 Fax (907) 451-5050 \\ dggspubs@alaska.gov \\ www.dggs.alaska.gov
}

\begin{abstract}
Alaska State Library
State Office Building, 8th Floor

333 Willoughby Avenue

Juneau, Alaska 99811-0571

Elmer E. Rasmuson Library

University of Alaska Fairbanks

Fairbanks, Alaska 99775-1005
\end{abstract}

\author{
Alaska Resource Library \& Information \\ Services (ARLIS) \\ 3150 C Street, Suite 100 \\ Anchorage, Alaska 99503-3982 \\ University of Alaska Anchorage Library \\ 3211 Providence Drive \\ Anchorage, Alaska 99508-4614
}

This publication was produced in Fairbanks, Alaska, by the Division of Geological \& Geophysical Surveys and is available for free download at www.dggs.alaska.gov, or for purchase as a printed document for $\$ 18.00$.

Publication is authorized by Alaska Statute 41, which charges the division ". . . to determine the potential of Alaskan land for production of metals, minerals, fuels, and geothermal resources; the location and supplies of groundwater and construction materials; the potential geologic hazards to buildings, roads, bridges, and other installations and structures; and . . . conduct such other surveys and investigations as will advance knowledge of the geology of Alaska." 


\section{CONTENTS}

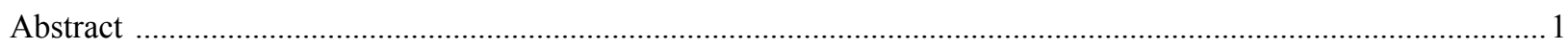

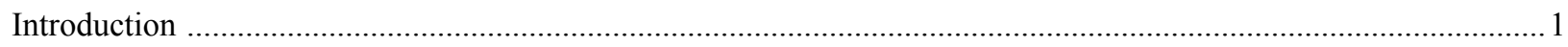

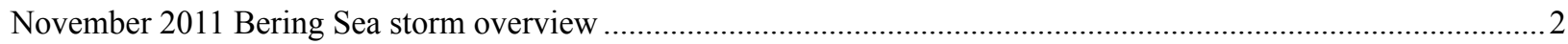

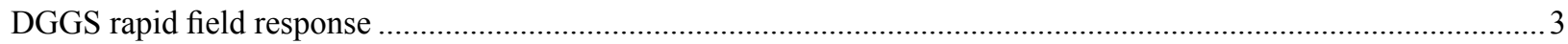

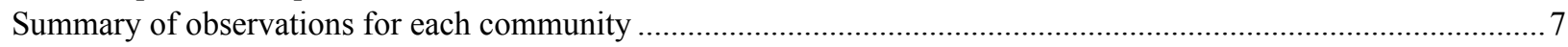

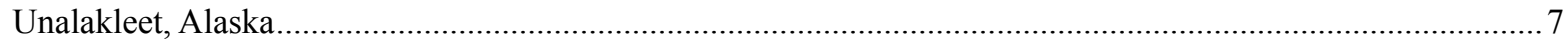

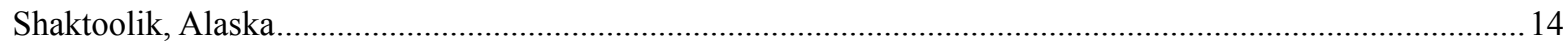

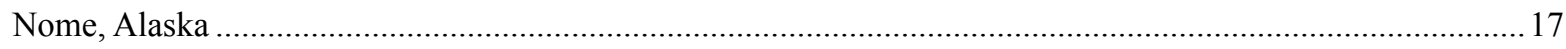

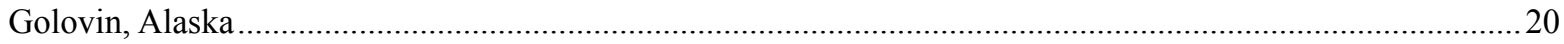

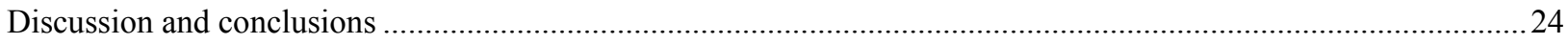

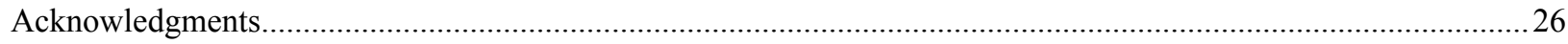

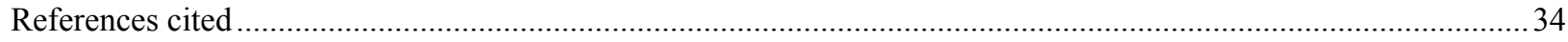

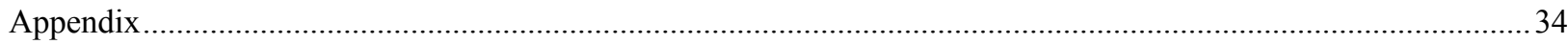

\section{FIGURES}

Figure 1. Satellite image of the extra-tropical cyclone described in this report as it tracks northeast across the Bering Sea...

2. Summary of the atmospheric pressure, water level, and surface winds in Nome for the duration of the November 2011 Bering Sea storm ............................................................................................. 3

3. Summary of the direction of surface winds from $11 / 6 / 11$ to $11 / 13 / 11$ in Nome, Golovin, and

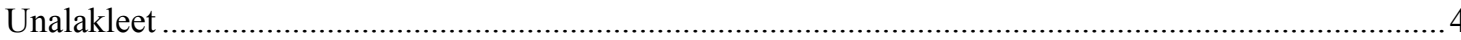

4. Timeline and map of DGGS rapid field response to the Norton Sound region following the

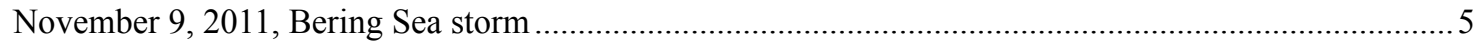

5. Definition drawing of the primary types of water levels referenced in this report ..................................6

6. Summary map depicting the locations of coastal profiles and points where flood indicators were measured in the vicinity of Unalakleet, Alaska ...................................................................... 8

7. Coastal modifications along the northern side of the Unalakleet River mouth including the armor rock revetment, gabion wall and sheet pile dock .......................................................................... 9

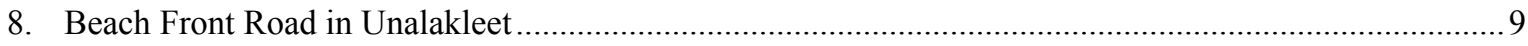

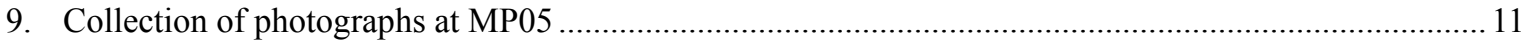

10. Photographs of flooded areas on open ocean side of Unalakleet........................................................ 12

11. Photographs of level of runup on side of raised Beach Front Road, Unalakleet .................................12

12. Coastal Profile 05, north of the Unalakleet barge landing, showing a well-developed mid-beach berm and rounded low bluff, and erosion of the bluff toe caused by waves during the November 2011 storm. Plots illustrating the change in the morphology of the beach cross section at this location including the removal of the berm, erosion at the bluff, and the accretion of ice ridges on the lower beach.

13. Summary map depicting the locations of coastal profiles and points where flood indicators were measured in the vicinity of Shaktoolik, Alaska .....

14. Location of elevated water level on the bank of Tagoomenik River November 9, 2011, and the measured point MP13_09 as determined by the position of the water relative to the upright support on the fish drying rack...

15. Inland limit of a runup deposit that overtopped the driftwood debris pile in front of the Native corporation building.

16. Photograph, looking to the south, of an area on the runway at the old Shaktoolik community site, where the barrier spit was overtopped and water flowed from Norton Sound into Tagoomenik River .... 17

17. Photograph showing basal notching $60 \mathrm{~cm}$ into the low coastal bluff at the old community site............ 18

18. Summary map depicting the locations of coastal profiles and points where flood indicators were measured along the Nome-Council Road east of Nome, Alaska ....

19. Examples of measured flood indicators along the Nome-Council Road from east to west ....................21 
20. Photographs of significant modifications to coastal engineering structures and damages along the Nome-Council Road...

21. Summary map of Golovin, Alaska, area including the location of fish camp shown relative to the position of the community

22. Dora Davis, a Chinik Eskimo Community grant writer, displays a preliminary version of the flood inundation map that was circulated by Golovin residents for collaborative feedback and edits prior to publication in this report

23. Total floodwater level as preserved in a truncated snowdrift on the sedimentary cliffs to the north of town, along the Golovnin Lagoon shoreline

24. Photos documenting the ivu that occurred at the mouth of Kachauik River..... 26

25. Oblique aerial image of the fish camp at the mouth of Kachauik River taken July 2012, eight months after the storm

26. Plots of the total range of peak storm surge predictions made for each visited community as a function of time based on output from 20 individual National Weather Service model runs that were executed every six hours from November 6 to November 11, 2011

27. Photographs taken near the runway at the old community site south of Shaktoolik illustrating the importance of a rapid response to collect useful measurements of storm surge elevations

\section{TABLES}

Table 1. A summary of the GPS processing options used to generate the coordinate measurements presented in this report

2. Elevations and descriptions of marine flood indicators measured in the vicinity of Unalakleet, Alaska, on November 11, 2011

3. Elevations and descriptions of marine flood indicators measured in the vicinity of Shaktoolik, Alaska, on November 12-13, 2011

4. Elevations and descriptions of marine flood indicators measured along the Nome-Council Road on November 14, 2011

5. Elevations and descriptions of marine flood indicators measured in Golovin, Alaska, on November 15, 2011.

6. A side-by-side compilation of November 9, 2011, Norton Sound tidal ranges and peak storm water levels as interpreted from various types of flood indicators that the DGGS team measured in the field ...28

\section{SHEET}

November 2011 Extent of Coastal Flood Inundation in Golovin, Alaska

\section{APPENDICES}

Appendix A. Atmospheric conditions in Unalakleet and Golovin. .33

B. Remeasured coastal profiles in Unalakleet and Shaktoolik, Alaska

C. Calculation of wave setup height based on published empirical relationship 


\section{ABBREVIATIONS}

\begin{tabular}{|c|c|}
\hline AHAP & Alaska High-Altitude Photography \\
\hline AKST & Alaska Standard Time (Coordinated Universal Time -9:00) \\
\hline CERC & $\begin{array}{l}\text { Coastal Engineering Research Center (United States Army Corps of Engineers } \\
\text { [USACE]) }\end{array}$ \\
\hline CIAP & $\begin{array}{l}\text { Coastal Impact Assistance Program (Bureau of Ocean Energy Management } \\
{[\text { BOEM]) }}\end{array}$ \\
\hline CORS & Continuously Operating Reference Station \\
\hline DCCED & Department of Commerce, Community \& Economic Development (State of Alaska) \\
\hline DEM & Digital Elevation Model \\
\hline DGGS & $\begin{array}{l}\text { Division of Geological \& Geophysical Surveys (State of Alaska, Department of } \\
\text { Natural Resources) }\end{array}$ \\
\hline DOT\&PF & Department of Transportation \& Public Facilities (State of Alaska) \\
\hline FAA & Federal Aviation Administration (United States Department of Transportation) \\
\hline FEMA & $\begin{array}{l}\text { Federal Emergency Management Agency (United States Department of Homeland } \\
\text { Security) }\end{array}$ \\
\hline GFS & Global Forecast System \\
\hline GNSS & Global Navigation Satellite System \\
\hline GPS & Global Positioning System \\
\hline MLLW & local Mean Lower Low Water level \\
\hline MODIS & Moderate Resolution Imaging Spectroradiometer \\
\hline MSL & Mean Sea Level (local unless otherwise noted) \\
\hline NASA & National Aeronautics and Space Administration \\
\hline NGS & $\begin{array}{l}\text { National Geodetic Survey (United States Department of Commerce, National } \\
\text { Oceanic and Atmospheric Administration) }\end{array}$ \\
\hline NOAA & $\begin{array}{l}\text { National Oceanic and Atmospheric Administration (United States Department of } \\
\text { Commerce) }\end{array}$ \\
\hline NRCS & Natural Resources Conservation Service (United States Department of Agriculture) \\
\hline NWS & $\begin{array}{l}\text { National Weather Service (United States Department of Commerce, National } \\
\text { Oceanic and Atmospheric Administration) }\end{array}$ \\
\hline OPUS & $\begin{array}{l}\text { Online Positioning User Service (United States Department of Commerce, National } \\
\text { Oceanic and Atmospheric Administration; } \underline{\text { http://www.ngs.noaa.gov/OPUS/) }}\end{array}$ \\
\hline PPK & Post-processed kinematic \\
\hline RTK & Real-time kinematic \\
\hline TWL & Total Water Level (storm surge + astronomical tide + wave setup) \\
\hline USACE & United States Army Corps of Engineers \\
\hline USGAO & United States Government Accountability Office \\
\hline USGS & United States Geological Survey (Department of the Interior) \\
\hline
\end{tabular}




\section{CONVERSION FACTORS \& GEOGRAPHIC REFERENCE FRAMES}

\begin{tabular}{|c|c|c|c|}
\hline & Multiply & by & To obtain \\
\hline \multicolumn{4}{|l|}{ Length } \\
\hline & centimeter $(\mathrm{cm})$ & 0.3937 & inch (in.) \\
\hline & meter $(\mathrm{m})$ & 3.281 & foot $(\mathrm{ft})$ \\
\hline & kilometer (km) & 0.6214 & mile (mi) \\
\hline \multicolumn{4}{|l|}{ Volume } \\
\hline & cubic meter $\left(\mathrm{m}^{3}\right)$ & 35.31 & cubic foot $\left(\mathrm{ft}^{3}\right)$ \\
\hline \multicolumn{4}{|l|}{ Rates } \\
\hline & knots & 1.1508 & miles per hour (mph) \\
\hline & meters/second $(\mathrm{m} / \mathrm{s})$ & 2.237 & miles per hour (mph) \\
\hline
\end{tabular}

Please note: All historic water level observations reported in feet in the original source material are presented in both feet and meters. All DGGS water level measurements were collected using metric units but some values are presented in both $\mathrm{m} / \mathrm{cm}$ and feet at the request of Norton Sound community residents.

\section{Datums}

Horizontal coordinate information is referenced to the North American Datum of 1983, NAD_83(2011)(EPOCH:2010).

Vertical coordinate information was converted from ellipsoid to orthometric heights, referenced to the North American Vertical Datum of 1988 (NAVD88), using GEOID09. Due to errors in the NGS GEOID09 for parts of Alaska, orthometric heights obtained using GEOID09 as opposed to local geodetic leveling may differ from true NAVD88 elevations.

The local transformations between geodetic and tidal datums used in this report are presented below. These values have been derived using 2010-2011 published orthometric heights of primary tidal benchmarks and local tidal station datum elevations from the 1983-2001 National Tidal Datum Epoch (NOAA, 2012).

Tidal stations and benchmarks used to generate datum conversion values

\begin{tabular}{|c|c|c|c|c|c|}
\hline \multirow[b]{2}{*}{ Location } & \multirow{2}{*}{$\begin{array}{l}\text { Tide } \\
\text { Station }\end{array}$} & \multirow{2}{*}{$\begin{array}{l}\text { Tidal datum } \\
\text { analysis period }\end{array}$} & \multicolumn{2}{|c|}{$\begin{array}{c}\text { Benchmark used for vertical } \\
\text { control }\end{array}$} & \multirow{2}{*}{$\begin{array}{l}\text { NAVD88 orthometric } \\
\text { height source }\end{array}$} \\
\hline & & & Stamping & $\begin{array}{c}\text { NGS } \\
\text { Position ID } \\
\text { (PID) }\end{array}$ & \\
\hline Unalakleet & 9468333 & $\begin{array}{c}07 / 01 / 2011- \\
08 / 31 / 2011 \\
\end{array}$ & 8333 H 2011 & BBCK34 & $\begin{array}{l}\text { Published OPUS solution from } \\
\text { July } 2011\end{array}$ \\
\hline Shaktoolik & 9468691 & $\begin{array}{c}07 / 15 / 2010- \\
08 / 23 / 2010\end{array}$ & 8691 A 2010 & BBBZ37 & $\begin{array}{l}\text { Published OPUS solution from } \\
\text { July } 2010\end{array}$ \\
\hline Nome & 9468756 & $\begin{array}{c}09 / 01 / 2008- \\
08 / 31 / 2010\end{array}$ & 8756 K 1992 & DF3653 & $\begin{array}{l}\text { Published OPUS solution from } \\
\text { July } 2011\end{array}$ \\
\hline
\end{tabular}

These conversions are presented as a convenience; they are subject to change and may vary in subsequent tidal epochs.

\begin{tabular}{|ccc|}
\hline Subtract & from & To obtain \\
\hline $1.465 \mathrm{~m}$ & NAVD88(GEOID09) & Elevation above local MSL in Unalakleet \\
$1.307 \mathrm{~m}$ & NAVD88(GEOID09) & Elevation above local MSL in Shaktoolik \\
$1.101 \mathrm{~m}$ & NAVD88(GEOID09) & Elevation above local MSL in Nome \\
& & \\
$0.923 \mathrm{~m}$ & NAVD88(GEOID09) & Elevation above MLLW in Unalakleet \\
$0.798 \mathrm{~m}$ & NAVD88(GEOID09) & Elevation above MLLW in Shaktoolik \\
$0.851 \mathrm{~m}$ & NAVD88(GEOID09) & Elevation above MLLW in Nome \\
\hline
\end{tabular}




\title{
COASTAL HAZARD FIELD INVESTIGATIONS IN RESPONSE TO THE NOVEMBER 2011 BERING SEA STORM, NORTON SOUND, ALASKA
}

\author{
by \\ N.E.M. Kinsman ${ }^{1}$ and M.R. DeRaps ${ }^{2}$
}

\begin{abstract}
On November 8, 2011, an extra-tropical cyclone with a low pressure of 945 millibars developed over the Bering Sea and moved northeast across the western coast of Alaska. This large storm brought high winds (gusts of up to 85 $\mathrm{mph}$ ) to the entire region and a storm surge of approximately 3 meters to parts of Norton Sound. In the week following the storm, a team of two DGGS scientists visited four communities in the Norton Sound region to document peak water levels, runup elevations, and inundation extents associated with the storm, and to revisit coastal profiles that were established in July 2011. This report is a summary of the reconnaissance fieldwork that was conducted in Unalakleet, Shaktoolik, Nome, and Golovin November 10-15, 2011.
\end{abstract}

\section{INTRODUCTION}

Flooding is Alaska's most common natural disaster and accounts for the majority of average annual monetary damages in the state (Alaska Department of Military and Veterans Affairs [DMVA], 2010). Flooding and erosion affect 184 out of 213, or 86 percent, of Alaska Native villages, many of which are located along the coast (U.S. Government Accountability Office [USGAO], 2003). Coastal storm surge is a leading cause of both flooding and erosion in the Norton Sound region of Alaska (USGAO, 2009), and the potential negative consequences of storms may be increasing with changing climatic trends, including the timing and extent of arctic sea ice cover (Douglas, 2010). Improved documentation of event-specific changes can significantly enhance mitigation or adaptation efforts to minimize loss of life and property associated with future storm events.

Storm surges are elevated ocean levels that arise from a combination of onshore-directed wind stresses that generate both wind and wave setup, and reduced atmospheric pressure. These temporary and rapid rises in sea level can lead to extensive coastal flooding and erosion, especially when they occur in unison with peak astronomical tides and large wind waves. In western Alaska, recurrent extreme storm surge events with heights greater than $3 \mathrm{~m}$ have been documented in records dating back to 1898 (Wise and others, 1981) and by oral histories that extend further (Glenn Gray \& Associates and others, 2012).

Norton Sound, on the west coast of Alaska, is particularly prone to severe storm surge for two primary reasons. First, the approximately $135 \mathrm{~km}$ mouth of this Sound is open to the west, exposing it to a long fetch across the Bering Sea. This orientation also makes the Sound positioned to 'trap' water along the path of extra-tropical cyclones that form in the midlatitude Pacific Ocean and migrate northeast. Second, Norton Sound's shallow depths averaging $20 \mathrm{~m}$ (Johnson and Kowalik, 1986; Blier and others, 1997) allow for significant storm surge amplification across the gently sloping, semi-enclosed embayment. As a result of these conditions, many low-lying coastal communities along the south- and west-facing coasts of Norton Sound have experienced periodic episodes of significant coastal flooding and erosion associated with the passage of large storms. Record storm surges in this part of Alaska have occurred primarily in the fall, from September through November. On average, three low-pressure systems with winds $>15$ meters/second move through the Norton Sound region each year (Johnson and Kowalik, 1986). Two of the most notable of the documented storm surges in Norton Sound occurred November 10-12, 1974 (4.1-6.4 m MSL in Nome; Wise and others, 1981; Fathauer, 1975), and October 2-4, 1960 (3.6 m MSL modeled in Shaktoolik; U.S. Army Corps of Engineers [USACE], 2011a). More recent storms with smaller resultant storm surge (3 m MSL in Nome) occurred in October 2004 (Hufford and Partain, 2004) and September 2005(USACE, 2011b).

Throughout the arctic, sea-ice freeze-up is occurring later in the year; since the 1970s, the Chukchi Sea just north of Norton Sound has experienced a trend of 6.9 days/decade delay in freeze-up (Perovich and Richter-Menge, 2009). Over this same period, total sea-ice cover in the Bering Sea has declined 26 percent per decade (Perovich and Richter-Menge, 2009). Reductions in sea-ice coverage and duration have the potential to increase the frequency and amplitude of storm surge because less sea ice translates to larger open-ocean fetch for the development of waves, and delayed shore-fast ice formation removes the ability of ice to act as a protective buffer against ocean energy during the peak storm season (Forbes, 2011). The role that delayed sea-ice formation plays in intensifying the effects of coastal storm surge has been anecdotally reported in many Norton Sound communities (for example, Native Village and City of Shaktoolik and others, 2009; City of Unalakleet and others, 2008).

Documentation of coastal hazards is notoriously sparse in the Norton Sound region; the fragmented record that exists is largely composed of scattered damage reports with a very limited number of often conflicting measurements.

1Alaska Division of Geological \& Geophysical Surveys, 3354 College Rd., Fairbanks, Alaska 99709-3707; nicole.kinsman@alaska.gov
${ }^{2}$ Alaska Division of Geological \& Geophysical Surveys, 3354 College Rd., Fairbanks, Alaska 99709-3707; meagan.deraps@alaska.gov 
Where efforts have been made to precisely document marine flooding, they have not always been sustained. For example, a flood-level marker on a utility pole in Golovin in the 1990s was not preserved when the utility system was relocated (USACE, 2011b). Baseline data are limited as well; the first permanent tidal gauge in Nome was not installed until 1992 (Blier and others, 1997) and it remains the only fixed water-level sensor in the region. Documentation of floodwater depths and aerial extents of inundation that have been historically absent from the records are crucial to efforts to improve storm forecast results (Wise and others, 1981). Numerous studies have also called for improved oceanic and atmospheric data collection in the region (for example, Johnson and Kowalik, 1986; Hufford and Partain, 2004). Quantification of event-specific erosion events is also necessary to improve estimates of long-term coastal retreat in the region (Sallenger and Dingler, 1978).

\section{NOVEMBER 2011 BERING SEA STORM}

The National Weather Service (NWS) issued an initial public information statement at 7:15 am AKST on November 7,2011 , that warned of a developing Bering Sea storm that would be similar to the Great Bering Sea Storm of 1974 (NWS, 2011). The NWS forecasted a peak storm surge of $10 \mathrm{ft}$ (approximately $3 \mathrm{~m}$ ) in parts of Norton Sound for the evening of November 8 to the morning of November 9, 2011. This statement cautioned that even though the peak surge was expected to be less than that of the 1974 storm (13.2 ft or $4.0 \mathrm{~m}$ at Nome), the protective ice cover that was along the northwest Alaska coastline in 1974 was absent, and that the 2011 storm would have "the potential to cause widespread damage." Additional NWS Public Information and Special Weather Statements were regularly issued over the following days containing updated storm surge and peak wind forecasts as well as predictions of areas expected to receive "widespread major coastal flooding and severe beach erosion."

The November 2011 storm, shown in the figure 1 satellite image, was typical of the large low-pressure storm systems that have generated significant surges in Norton Sound in the past. Winds associated with the storm system varied in direction and strength along the Norton Sound coastline. Nome experienced sustained onshore winds of nearly 40 knots and gusting winds in excess of 50 knots (figs. 2 and 3). Peak winds in Unalakleet and Shaktoolik were of a similar magnitude

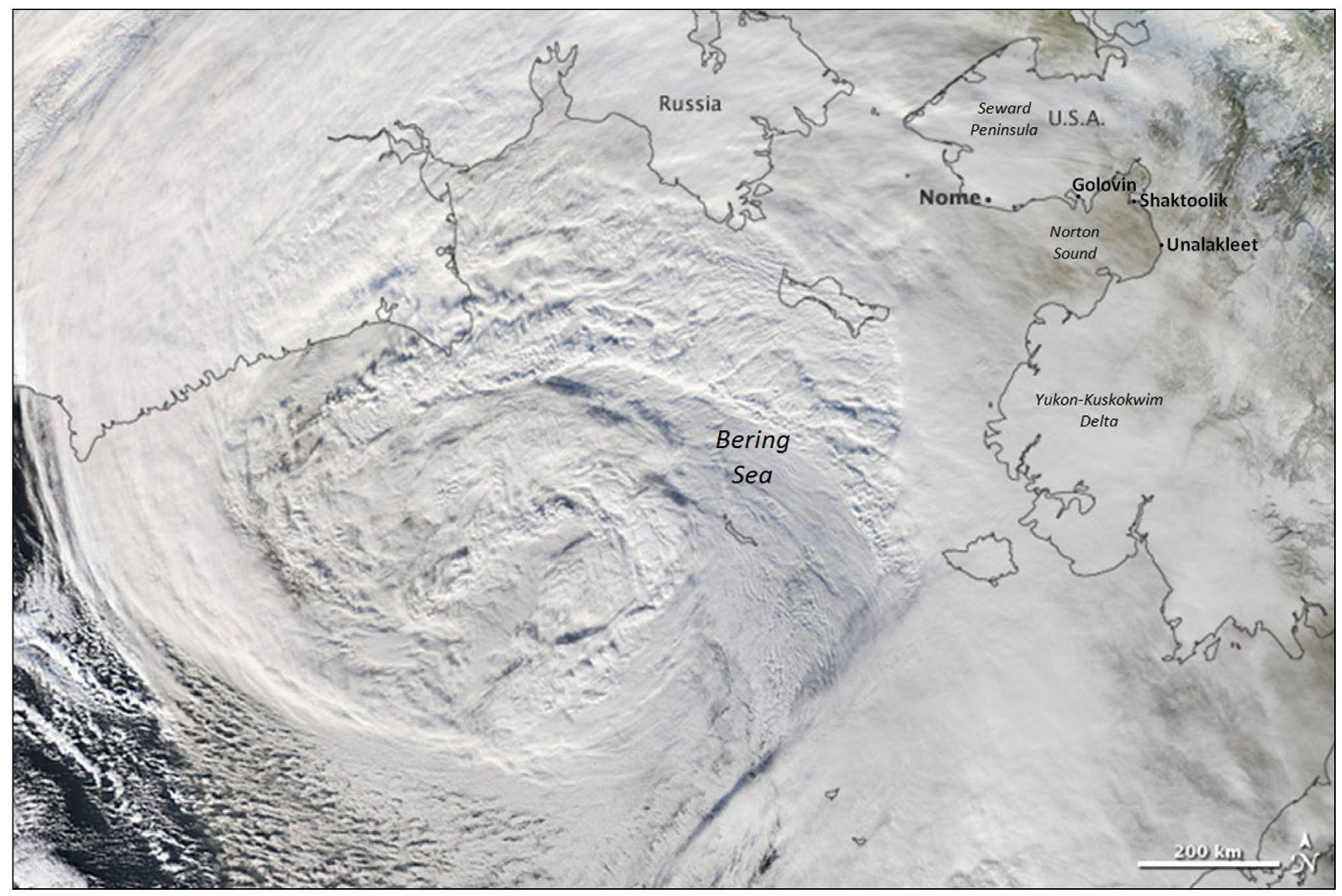

Figure 1. Satellite image (taken November 8, 2011, 2:45 pm AKST) of the extra-tropical cyclone described in this report as it tracks northeast across the Bering Sea. The locations of the four communities described in detail are shown in bold. (Modified from image by Jesse Allen; data obtained from NASA's Land Atmosphere Near-real-time Capability for EOS, NASA Earth Observatory, Online.) 


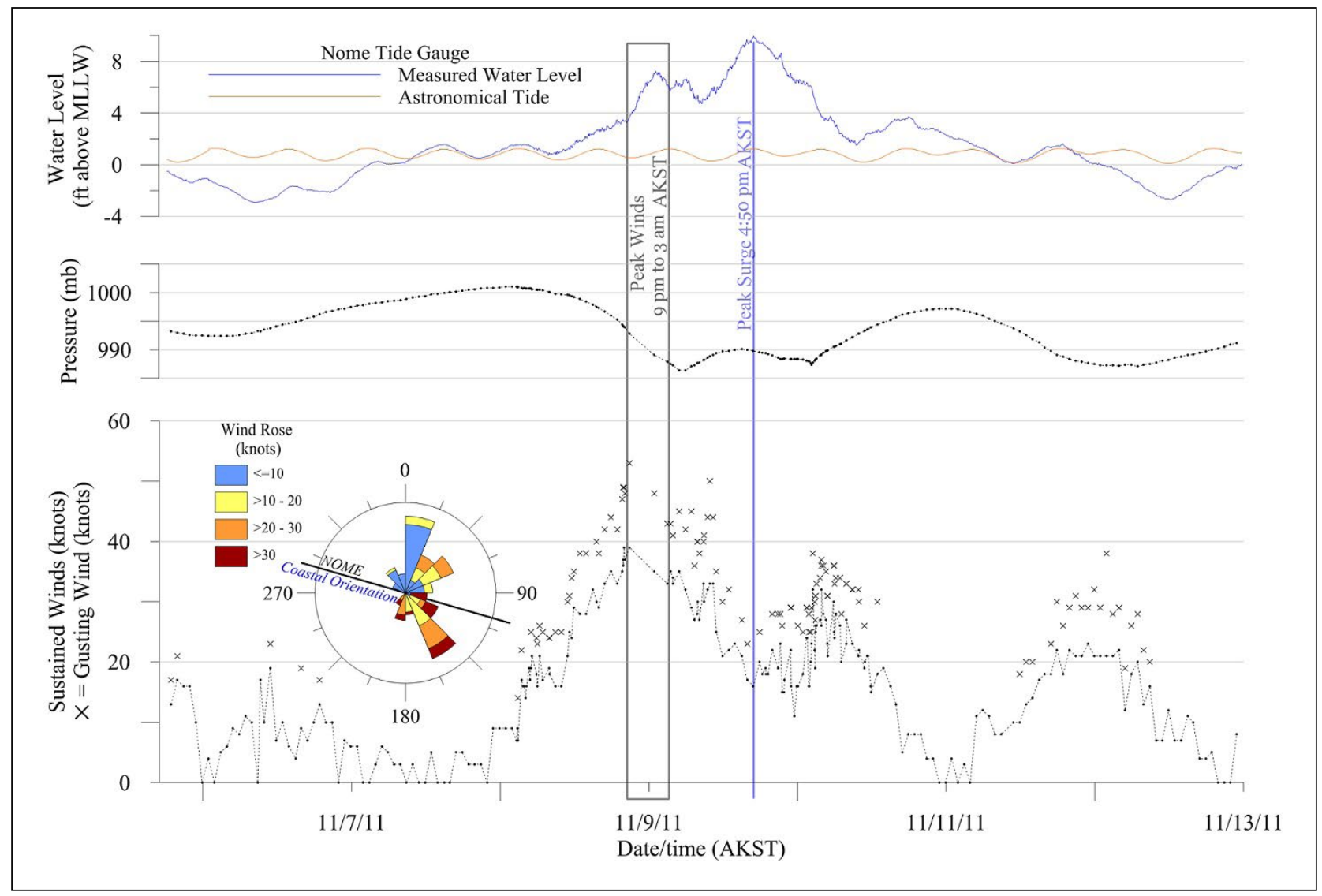

Figure 2. Summary of the atmospheric pressure, water level, and surface winds in Nome for the duration of the November 2011 Bering Sea storm. The wind rose diagram depicts the percentage of time between 11/6/11 and 11/13/11 that the winds were blowing from a particular direction. Plots were generated with data from the automated weather station at the Nome airport and the NOAA tide gauge at the mouth of the Snake River.

but in an offshore direction during the storm. Peak winds in Norton Sound arrived between midnight and 3 am AKST on November 9, 2011, and strong winds occurred again on November 10 and 12, associated with smaller storm systems (see Appendix A for additional information regarding atmospheric conditions in Unalakleet and Golovin).

The peak storm surge arrived between the hours of 3 and 5 pm AKST on November 9, 2011, at most locations in Norton Sound. With an approximately 12-hour lag between the peak winds and crest of the storm surge, the majority of severe flooding fell within a low wind 'window' throughout the region. Measurements of maximum water level during this storm were made by the tidal gauge in Nome, operated by NOAA (fig, 2; raw data available online at http:// tidesandcurrents.noaa.gov/geo.shtml? location=9468756). The peak surge in Nome coincided with the astronomical high tide of $0.12 \mathrm{~m} \mathrm{MSL}$, increasing the overall water level. Notably, coastal flooding occurred during daylight hours during this event and water levels in the Norton Sound region crested just prior to local sunset.

On December 5, 2011, Alaska Governor Sean Parnell declared a State Disaster Emergency for the series of sea storms that struck the West Coast of Alaska from November 7, 2011, through November 13, 2011 (Parnell, 2011). At the time of the declaration, damages in 37 cities and villages had been estimated at $\$ 29.9$ million. The majority of damages were caused by high winds and coastal flooding. Governor Parnell's action was followed by a Federal Alaska Disaster Declaration that was signed by President Barack Obama on December 22, 2011.

\section{DGGS FIELD RESPONSE}

In 2009, the Alaska Division of Geological \& Geophysical Surveys (DGGS) received federal funding from the U.S. Minerals Management Service (now Bureau of Ocean Energy Management) through the Coastal Impact Assistance Program (CIAP) to establish a new coastal community geohazards evaluation and geologic mapping program in support of local and regional planning. In summer 2011, field efforts were focused on the eastern Norton Sound coastline in the communities of Unalakleet and Shaktoolik. These activities consisted of collecting extensive baseline data pertaining to local geology, coastal and oceanic processes, and historic natural hazard events in and around the communities. Part of this work included the establishment of baseline profile measurements or 'elevation snapshots' of the coast. 


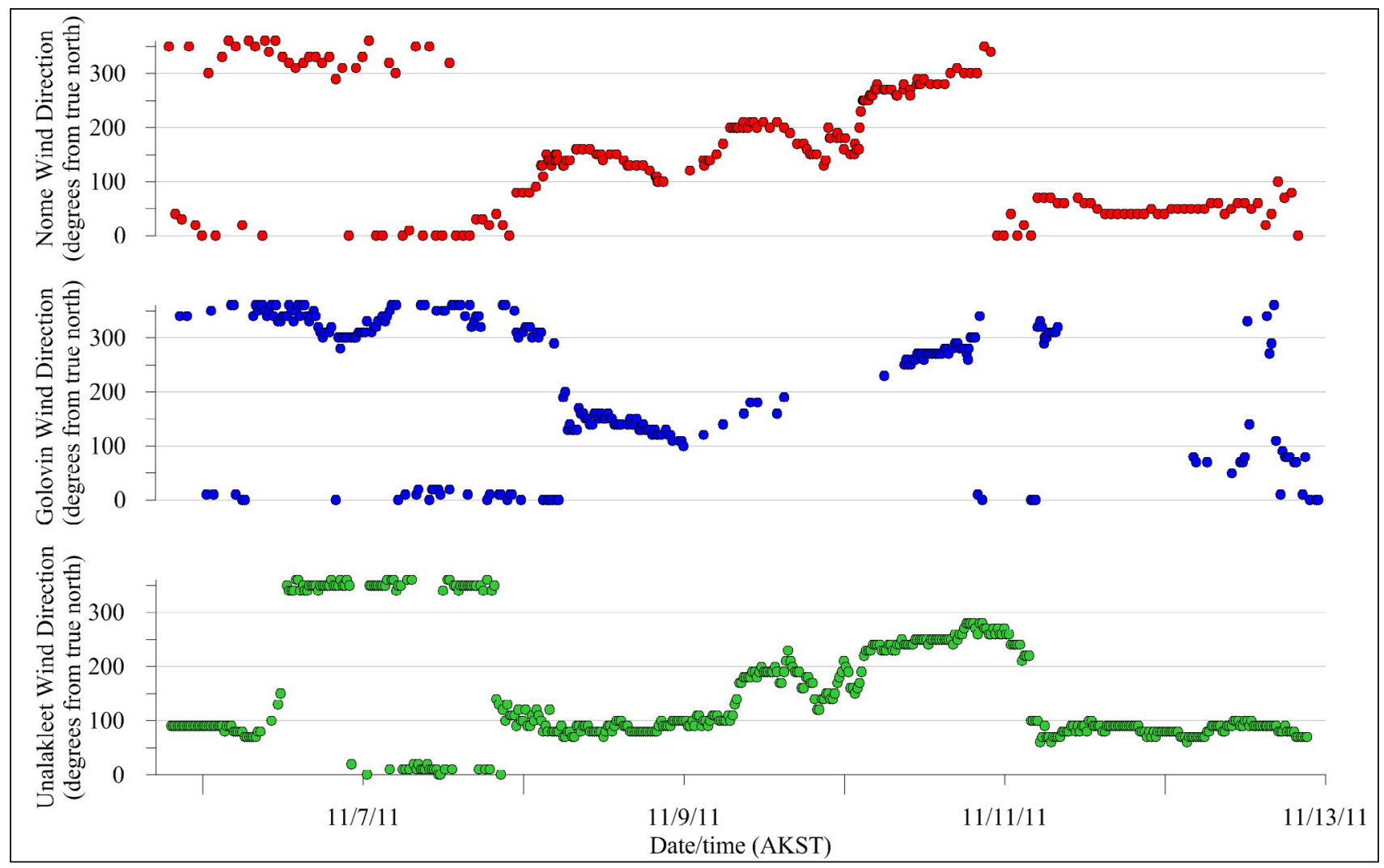

Figure 3. Summary of the direction of surface winds from 11/6/11 to 11/13/11 in Nome, Golovin, and Unalakleet. Wind directions are in degrees from true north so the minimum y-axis value of 0 is equivalent to the maximum value of 360. Plots were generated with data from the automated weather stations at the respective airports.

Immediately after the initial NWS public information statement that predicted landfall of a very large Bering Sea storm, a team of two DGGS coastal geologists began preparations for travel to Norton Sound in the wake of the storm to revisit areas mapped during the previous summer and to document the effects of the storm in these and other communities. By maintaining communications with observers on the ground in Unalakleet and Shaktoolik and at the Incident Command Center in Anchorage, the team conducted a safe, one-week series of community visits to four affected areas (fig. 4). The primary objectives of this trip were to:

1. Formally document the extent of coastal flooding (including local peak water level elevations)

2. Remeasure coastal profiles to quantify event-specific rates of erosion and profile modification

3. Collect photographs, video, and direct observations from residents

Several types of water levels are described in this report; these are summarized visually in figure 5. The storm tide level is the height of the storm surge superimposed upon the height of the astronomical tide (storm tide $=$ storm surge + astronomical tide). Wave setup (or setdown if negative) is an additional factor that affects water levels in the nearshore and is caused by a transfer of momentum in the surf zone. Total Water Level (TWL) is used to describe the storm tide level in combination with wave setup (TWL $=$ storm surge + astronomical tide + nearshore wave setup). In sheltered areas where wave setup is negligible, the TWL is equal to the storm tide level. Additionally, wave runup is used to refer to the maximum height to which breaking waves can reach on a shoreface. Measurements of these individual or combined factors are required to calibrate improved storm surge models and to create inundation maps.

For the documentation of coastal flooding and water level elevations, a wide range of field methods were adopted by the DGGS team based on flood indicators and the available resources in each community. These included the measurement of debris lines, water and slush limits in the snow, and elevations of visibly overtopped or inundated areas. The team also employed methods that involved the use of the FAA Aviation Camera program network and photographs provided by residents to reconstruct inundation extents. Each measured flood indicator was assigned a qualitative confidence level to reflect the validity of inferring marine flood levels from the measurement. High confidence was applied to locations where evidence of a discrete water level was readily observed in the field (slush lines, for example). Medium confidence was applied to points that were measured at the 


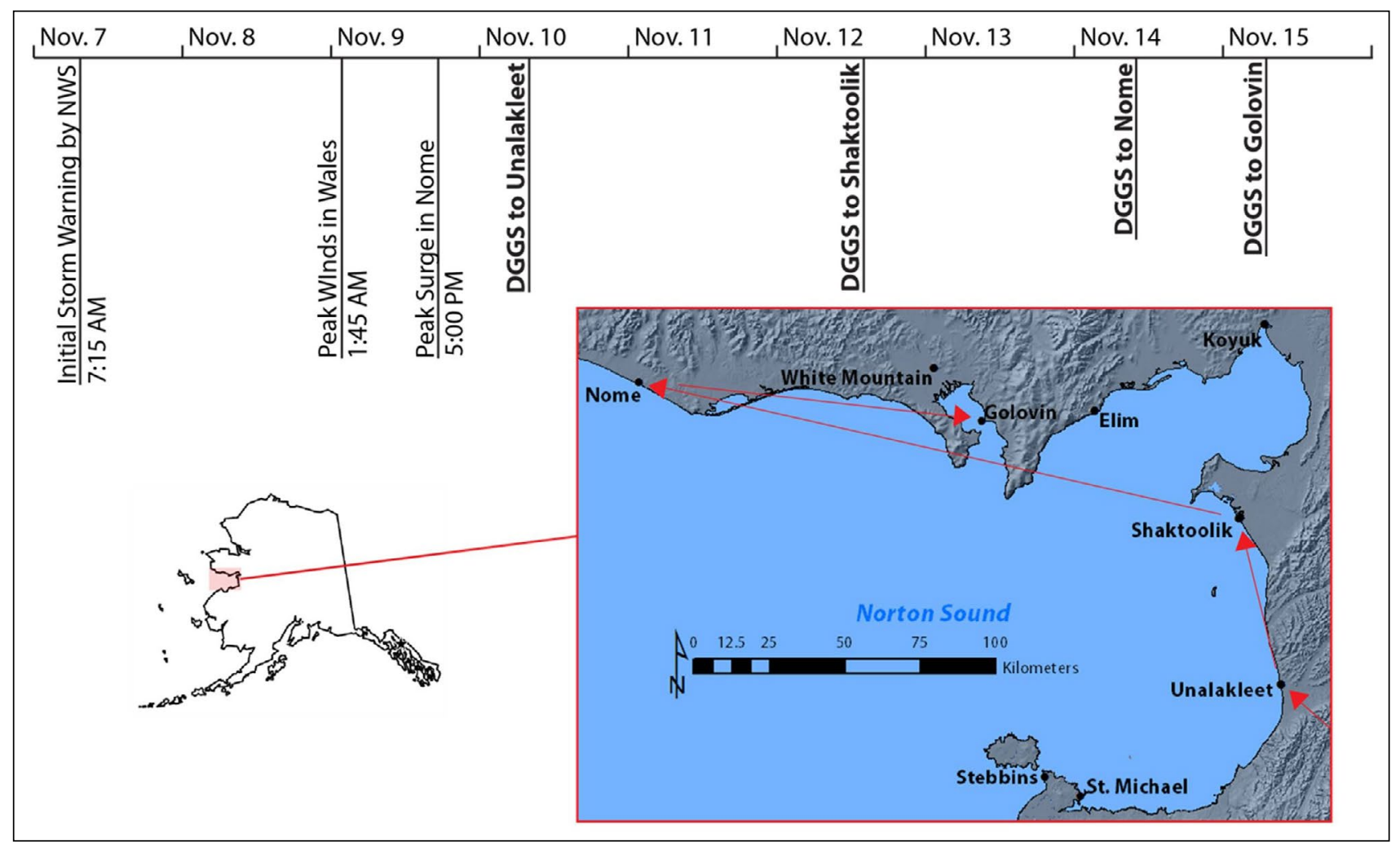

Figure 4. Timeline and map of DGGS rapid field response to the Norton Sound region following the November 9, 2011, Bering Sea storm. The DGGS team was on the ground within 24 hours of the peak storm surge in Unalakleet.

best approximation of the water position based on partially obscured or indiscrete evidence (tension cracks in snow or many of the photo-identified points, for example). Lowest confidence was applied to points where the role of floodwater in the creation of a flood indicator was ambiguous, where locations were identified solely from the memories of residents, or where clean-up activities had modified the site enough to conceal the exact location of the flood extent. These assigned confidence levels were used to weight vertical measurements in the determination of average inferred water level elevations for each community. We used the measurements of sheltered inundation limits/water levels to approximate the storm tide levels (surge + tide); inundation limits/standing water levels on exposed coasts were used to approximate TWL (surge + tide + nearshore wave setup), and water-limit measurements collected directly above the surf zone were used to infer the maximum elevation of wave runup (fig. 5).

The importance of a rapid response to document coastal storm damage has been widely recognized (for example, Doran and others, 2009) because of the swift nature with which coastal areas undergo modification and the prevalence of rapid clean-up efforts that remove useful flood indicators shortly after an event. This is especially true in rural Alaska, where high winds and snow can quickly obscure evidence of flooding. Because of these rapidly changing conditions, our team would not have been able to collect many of the measurements included in this report beyond the one-week time span immediately following the storm. Additionally, we used the residents' photos from during the storm to reoccupy positions of inundation limits using 'landmarks' unlikely to remain in position through the spring, such as dry-docked boats and damaged fish drying racks.

For both the flood indicators and coastal profiles, precise horizontal and vertical measurements were collected with a survey-grade GPS system consisting of two dual frequency Topcon HiPer II GNSS receivers and a Topcon FC-250 field controller running TopSURV software. Due to varying time constraints in the field and limited benchmark access in some communities, we employed one of three different methods to obtain coordinates for each measured location: (1) In Unalakleet, we used RTK and PPK with local NGSpublished geodetic control, (2) in Shaktoolik, we used PPK by establishing a local geodetic control, and (3) in Nome and Golovin, we used PPK without local geodetic control. These methods, and their associated error magnitudes, are summarized in table 1. Method 1 involved setting up the base receiver over a local benchmark (NGS PID DM4448, datasheet last updated in 2010) with published coordinates. The team was able to use this method (preferred for high accuracy) in Unalakleet because we had adequate time in the field and had transportation to and from the benchmark location. When available, RTK allowed us to get real-time position corrections in the field, aiding in the reoccupation of the coastal profiles. In areas with no RTK signal, PPK locations were 


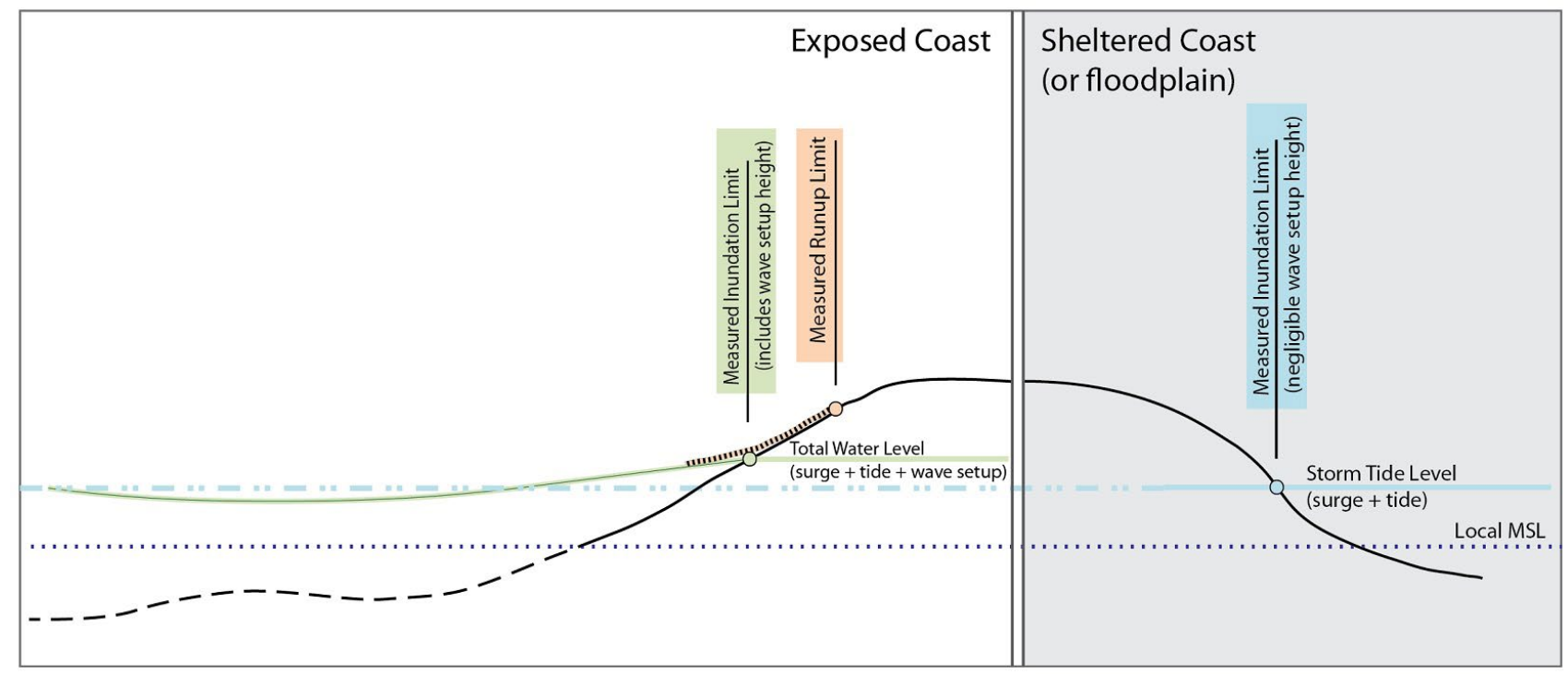

Figure 5. Definition drawing of the primary types of water levels referenced in this report: storm tide level (surge + tide; blue) measured along wave-sheltered coastlines, TWL (surge + tide + wave setup; green) measured along the open coast, and wave runup (orange if maximum observed in inhabited community and red if maximum observed in the broader community area).

later post-processed from the base receiver data. Method 2 involved setting up the base receiver over a location without published control and performing a 10-hour static occupation. The static occupation was then post-processed with data from NGS CORS and used as control for the PPK measurements. Method 3 yielded lower accuracies than methods 1 and 2 and was only used when the team lacked available time and resources to transport and set up the base receiver. For this method, only the roving receiver was used and the kinematic points collected were post-processed directly with the NGS CORS data. The four CORS stations that were used in the post-processing of the Method 2 and Method 3 data were AB11 (Nome), AB17 (Unalakleet), AC07 (Buckland), and AC31 (Bald Head).

The errors presented for each vertical measurement in this report encompass both coordinate precision and positional accuracy. The precision value is the standard deviation of the post-processed data calculated using Topcon Tools software (see range of values presented by both method type and community in table 1). All vertical accuracies (summarized by community in table 1) were evaluated by comparison with known elevations such as a published benchmark or the water level at time of measurement. In Unalakleet, the occupation of a benchmark (NGS PID BBCK34) with a published elevation revealed a vertical accuracy of $2 \mathrm{~cm}$, a value consistent with the GPS manufacturer's reported specifications. In Shaktoolik, a comparison between the measured elevation of the roadway on Profile 20/21 and a July 2011 measurement of the roadway surface yielded a vertical accuracy of $4 \mathrm{~cm}$. In Nome, vertical measurements of the calm water level at three profile locations were compared to the elevation of the water as recorded by the NOAA tidal gauge (Station

Table 1. A summary of the GPS processing options used to generate the coordinate measurements presented in this report. The experimental precision values are based on a 2011 controlled test of DGGS GNSS equipment, conducted in Unalakleet, Alaska, and do not include error associated with positional accuracy. The actual precision values were calculated with post-processing software and the accuracies were determined by comparison with an independently derived vertical NAVD88 elevation such as a benchmark or known water level.

\begin{tabular}{|c|c|c|c|c|c|c|c|}
\hline & \multirow{2}{*}{$\begin{array}{c}\text { Experimental } \\
\text { Horizontal } \\
\text { Precision }\end{array}$} & \multirow{2}{*}{$\begin{array}{c}\text { Experimental } \\
\text { Vertical } \\
\text { Precision } \\
\end{array}$} & \multirow[b]{2}{*}{ Community } & \multicolumn{4}{|c|}{ Actual values for reported positions $(\mathrm{cm})$} \\
\hline & & & & $\begin{array}{l}\text { Horizontal } \\
\text { Precision }\end{array}$ & $\begin{array}{l}\text { Vertical } \\
\text { Precision }\end{array}$ & $\begin{array}{l}\text { Vertical } \\
\text { Accuracy }\end{array}$ & $\begin{array}{c}\text { Total Vertical } \\
\text { Error }\end{array}$ \\
\hline \multirow{2}{*}{ Method 1} & $0.6 \mathrm{~cm}(\mathrm{RTK})$ & $1.1 \mathrm{~cm}(\mathrm{RTK})$ & \multirow{2}{*}{ Unalakleet } & \multirow{2}{*}{$2.0-4.3$} & \multirow{2}{*}{$1.4-2.9$} & \multirow{2}{*}{2} & \multirow{2}{*}{$3-5$} \\
\hline & $2.4 \mathrm{~cm}(\mathrm{PPK})$ & $3.0 \mathrm{~cm}(\mathrm{PPK})$ & & & & & \\
\hline Method 2 & $2.1 \mathrm{~cm}$ & $2.6 \mathrm{~cm}$ & Shaktoolik & $1.7-16$ & $2.2-23.5$ & 4 & $6-28$ \\
\hline \multirow{2}{*}{ Method 3} & \multirow{2}{*}{$19 \mathrm{~cm}$} & \multirow{2}{*}{$29 \mathrm{~cm}$} & Nome & $2.5-24$ & $3.4-31.0$ & 16 & $19-47$ \\
\hline & & & Golovin & $4.1-9.6$ & $5.6-15.0$ & 51 & $57-66$ \\
\hline
\end{tabular}


9468756) at the time of the measurements. The maximum observed variation between the measured elevations and the elevations recorded by the tidal gauge indicates a vertical accuracy of $16 \mathrm{~cm}$ for these values. In Golovin, vertical coordinates calculated using the CORS data were compared to a DEM surface published by DCCED (Alaska Department of Commerce, Community \& Economic Development, 2004; NGVD29 to NAVD88 conversion completed with the use of DOT\&PF airport benchmark 'COR2'). Variation between the measured elevations and the published DEM elevations yields an accuracy of $51 \mathrm{~cm}$ for the vertical measurements included on the Golovin map.

While high winds, short days, cold temperatures, and snow limited the team's ability to access some areas that could be reached in the summer months, the expertise and experience of local residents provided the DGGS team with critical information in the form of photographs and video that were used to compile a better understanding of how this storm affected each community that was visited. For example, observations of the patterns of slush and ice movement in the nearshore and how this contributed to the attenuation of wave energy highlighted differences in coastal flooding between this storm and previous storm events.

\section{SUMMARY OF OBSERVATIONS FOR EACH COMMUNITY}

\section{Unalakleet}

Unalakleet, located at the mouth of Unalakleet River and west of the Nulato Hills, has a population of 688 (U.S. Census Bureau, 2010). The community is situated on a sand and gravel barrier spit that is bounded to the west by Norton Sound, to the south by the river inlet, and to the east by Kouwegok Slough (fig. 6). The area experiences a mean tidal range of $97 \mathrm{~cm}$ (NOAA, 2012).

Extreme storm surges were recorded in Unalakleet in 1960 (20 ft or $6.1 \mathrm{~m}$ MSL; Wise and others, 1981), 1965 (18ft or $5.5 \mathrm{~m} \mathrm{MSL}$ ) and 1974 (15ft or 4.6 MSL) (USACE, 2011b). The 1960 event moved structures off of their foundations and put the power plant out of operation, whereas the 1965 event triggered an evacuation (Wise and others, 1981). Other notable coastal flooding events occurred in October and November 2004, when a gabion wall at the river mouth was damaged (City of Unalakleet and others, 2008), in 1963, resulting in $\$ 100,000$ in damages, and also in 1973, 1966 (Wise and others, 1981), and 1937 (unconfirmed, NRCS, 2003).

Engineering modifications to the Unalakleet coastal zone include an armor rock revetment with a crest elevation of $23 \mathrm{ft}$ $(7.0 \mathrm{~m})$ above MLLW that extends around the southern perimeter of the spit (USACE, 2008). The current revetment project was completed in 2010 by the Army Corps of Engineers and included replacement of the seaward segment of a damaged gabion wall that was originally constructed in 2000 by the Natural Resources Conservation Service (fig. 7a). A sheet pile dock abuts the gabion wall on the inside of the inlet (fig. 7c). Beach Front Road, which runs along the seaward edge of the spit, was elevated by $3 \mathrm{ft}(0.9 \mathrm{~m})$ in 2005 (fig. 8). In 2008, Alaska DOT\&PF constructed a 'dynamically stable' beach project along the portion of coast that fronts the road to the airport and the southern end of Runway 33 . The engineered beach had an initial crest width of $20 \mathrm{ft}(6.1 \mathrm{~m})$ and was designed to undergo gradual modification by marine energy to an equilibrium profile with a crest width of $10 \mathrm{ft}$ (3.0 m; Smith and Carter, 2011).

November 2011 DGGS field investigations in Unalakleet consisted of two days of fieldwork during which our team was able to reoccupy nine of the coastal profiles established in summer 2011, measure 15 marine flood indicators, and collect photographs and video from residents (summarized in fig. 6). The results of measurements made to evaluate the peak water level elevations in Unalakleet are presented in table 2.

Inundation limits on the Kouwegok Slough side of the community are most indicative of a surge tide level because this area was protected from wind waves. Our team measured a water level elevation of $2.7 \mathrm{~m}$ (9 ft) MSL alongside Runway 26 (fig. 9) and at the crane on the sheet pile dock (fig. 6d); we interpret this to be the peak water level attributed to the storm surge and astronomical tide. On the seaward side of the community where wave setup resulted in an additional increase in water level, the floodwater levels reached $4.2 \mathrm{~m}$ (14 ft) MSL (fig. 10). We were able to document maximum wave runup elevations in the community of up to $5.8 \mathrm{~m}(19$ $\mathrm{ft}$ ) MSL along the raised Beach Front Road (fig. 11a) and at the airport (fig. 11b). Near the barge landing and farther to the north, where beach and surf zone are narrower and breaking waves dissipate less energy in the nearshore, we observed

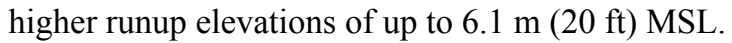

Remeasured beach profiles in front of the community (profiles 15 and 16, fig. 6) revealed no modification other than the accretion of a ridge of ice at approximately $2.5 \mathrm{~m}$ MLLW. Profiles north of the community near the barge landing site indicate the removal of mid-beach gravel berms that were present in the summer. The removal of these berms by fall storms is typical of seasonal beach cycle modification and do not represent a permanent change to the beach morphology. Permanent and irreversible erosion of the back beach was observed at the northernmost profile (profile 5) that was remeasured. Numerous block failures at the edge of the low bluff along the road to Blueberry Creek were observed up and down the coast in the vicinity of this profile (fig. 12b). The plots in figure 12 illustrate the pre- and post-storm beach profiles at this location. The initial profile collected in July 2011 (green) has a mid-beach gravel berm at $3 \mathrm{~m}$ MLLW and a rounded, low bluff typical of terrestrial weathering processes (see fig. 12a). The post-storm profile reveals a sharp, vertical bluff at the backbeach, caused by basal marine erosion, and a bluff edge retreat of $2.3 \mathrm{~m}$ inland. A complete set of plotted profile change figures is included in Appendix B. A remeasured vegetation line on the Kouwegok Slough side of the community revealed no erosion or retreat in this area. 


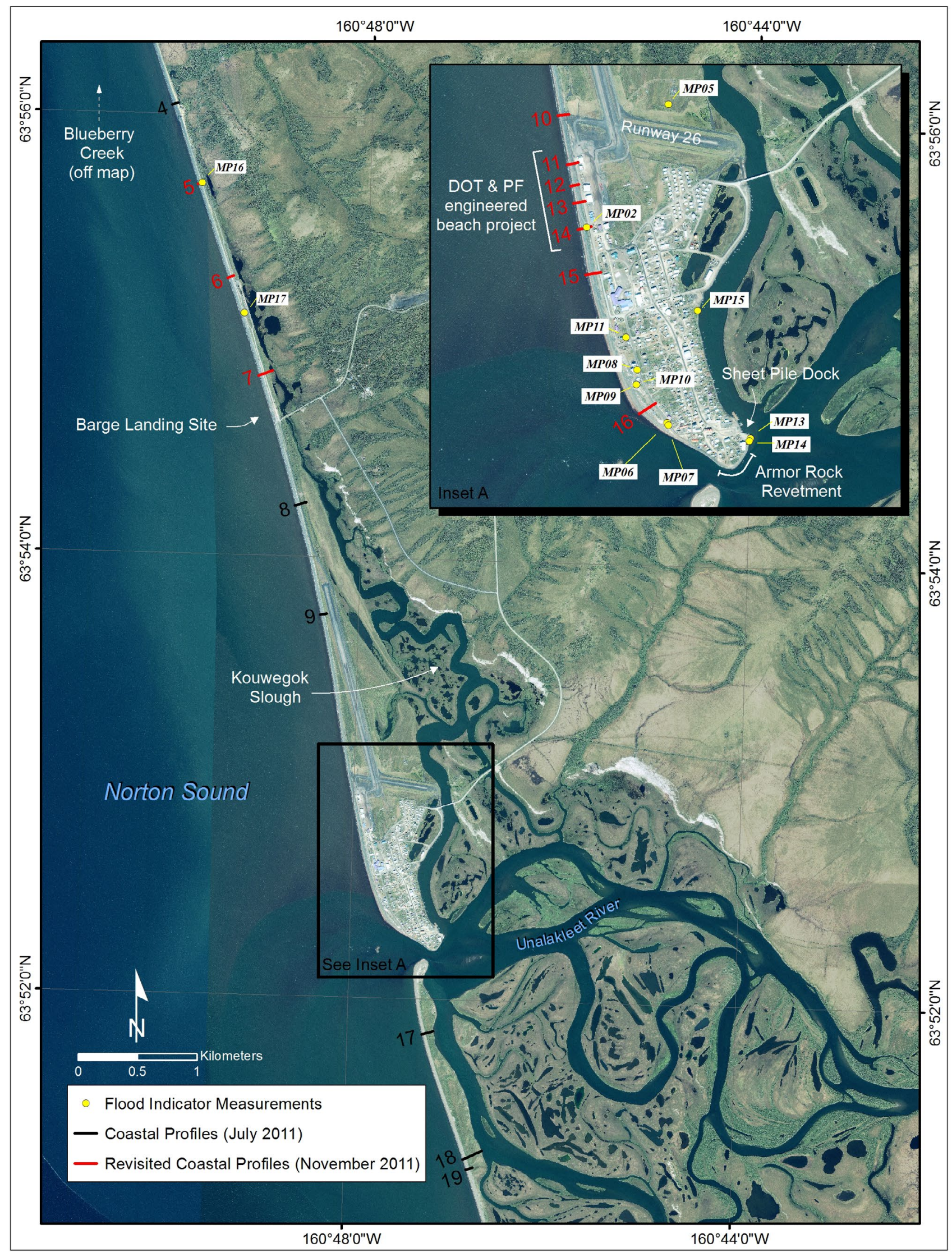

Figure 6. Summary map depicting the locations of coastal profiles and points where flood indicators were measured in the vicinity of Unalakleet, Alaska. The base map is a 2005 IKONOS satellite image. 

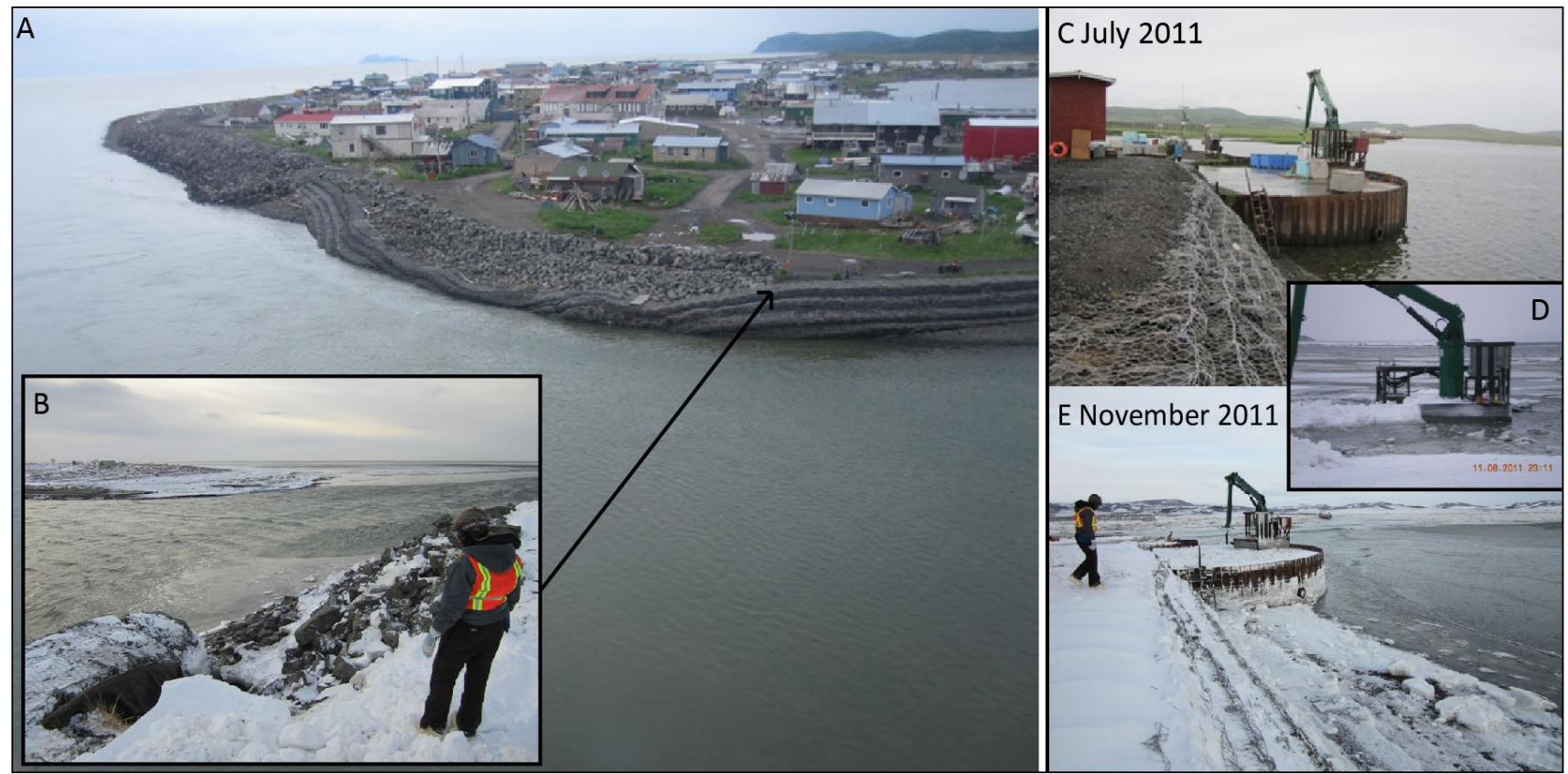

Figure 7. Coastal modifications along the northern side of the Unalakleet River mouth including the armor rock revetment, gabion wall and sheet pile dock. The gabion wall is shown (a) in a pre-storm oblique aerial photo and (b) when a blowout was observed post-storm. The sheet pile dock is shown (c) pre-storm, (d) at the peak surge (photo by Maggie Halleran), and (e) again post-storm. MP14 in table 2 was collected at the crane site.

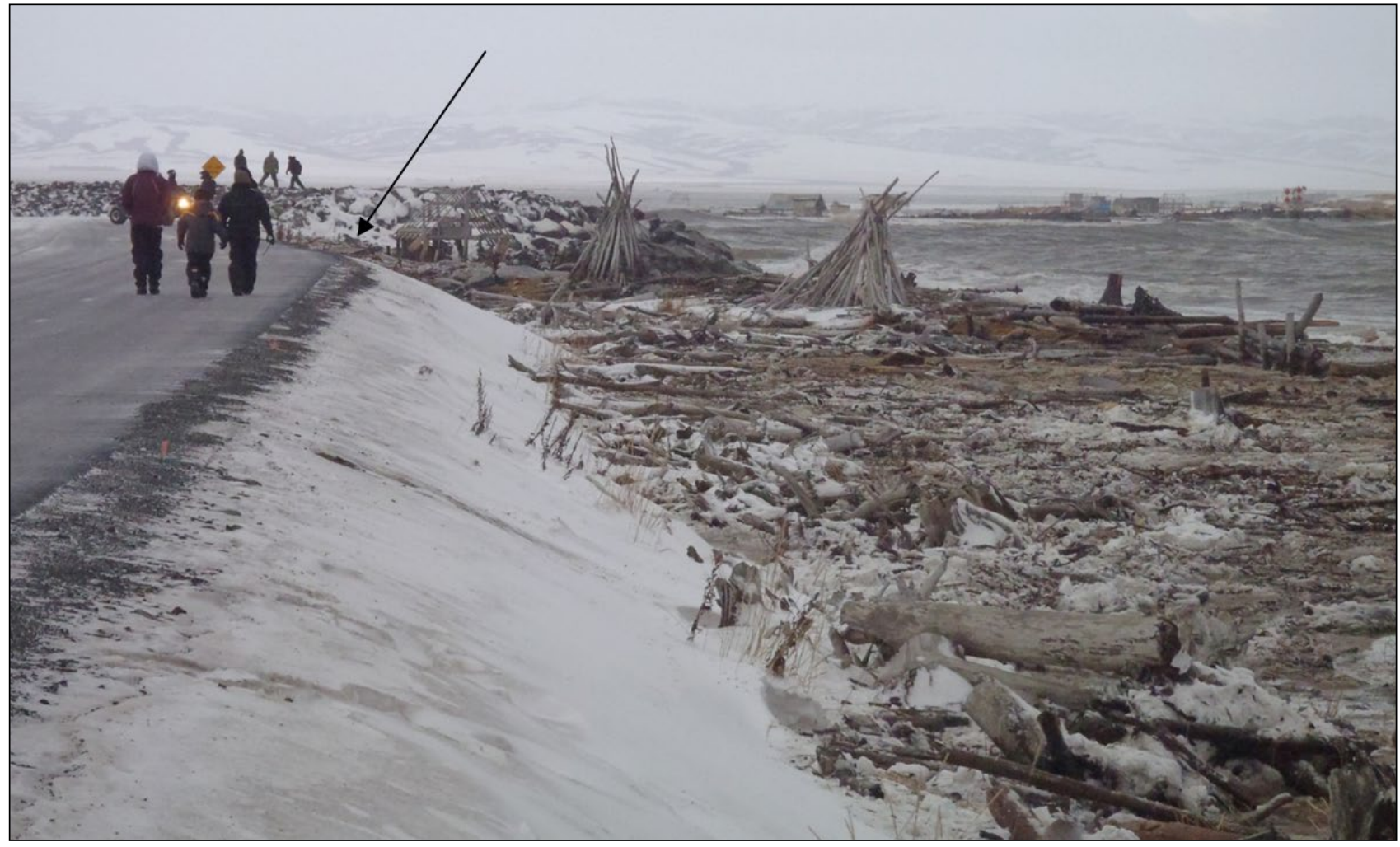

Figure 8. Beach Front Road in Unalakleet, which runs along the coast exposed to Norton Sound, was raised approximately $3 \mathrm{ft}(0.9 \mathrm{~m})$ in 2005. The western terminus of the armor rock revetment is visible in the photo and the arrow points to a location along the road where runup measurements MP06 and MP07 (table 2) were collected (photo by Steve Ivanoff). 
Table 2. Elevations and descriptions of marine flood indicators that were measured in the vicinity of Unalakleet, Alaska on November 11, 2011. Point numbers not preceded by 'MP' were collected along coastal profiles (for example, 15_02 was the second point collected on Profile 15). Measurements used to infer different types of water level elevations during the peak storm surge are highlighted: Storm tide (surge + tide; blue), TWL (surge + tide + wave setup; green), maximum wave runup within the inhabited community (orange) and maximum observed runup in the entire area (red).

\begin{tabular}{|c|l|c|c|l|}
\hline $\begin{array}{c}\text { Point } \\
\text { Number }\end{array}$ & $\begin{array}{c}\text { Measurement } \\
\text { Type }\end{array}$ & $\begin{array}{c}\text { Confidence } \\
\text { Level }\end{array}$ & $\begin{array}{c}\text { Elevation } \\
\text { (m MSL) }\end{array}$ & \multicolumn{1}{|c|}{ Description } \\
\hline MP15 & Inundated area & High & $0.92 \pm 0.05$ & $\begin{array}{l}\text { Elevation of rafted river ice on bank of Kouwegok } \\
\text { Slough }\end{array}$ \\
\hline MP13 & Inundated area & High & $1.07 \pm 0.05$ & Elevation of rafted ice chunks near sheet pile dock \\
\hline MP05 & Inundation limit & Medium & $2.66 \pm 0.06$ & $\begin{array}{l}\text { Identified on FAA camera image, north of Runway } \\
26\end{array}$ \\
\hline MP14 & Peak flood level & High & $2.66^{*} \pm 0.04$ & Elevation of visible water line on side of dock crane \\
\hline MP11 & Inundated area & High & $3.24 \pm 0.04$ & Spillover point identifiable in photograph from storm \\
\hline MP09 & Inundated area & Medium & $3.85 \pm 0.04$ & Toe of scarped beach gravels on shoreface \\
\hline MP08 & Inundation limit & High & $4.20 \pm 0.05$ & Slush limit adjacent to a garage that was flooded \\
\hline MP10 & Above inundation & Lowest & $4.32 \pm 0.05$ & Top of scarped beach gravels on shoreface \\
\hline MP07 & Runup limit & Medium & $4.82 \pm 0.05$ & $\begin{array}{l}\text { Slush line with driftwood, raised Beach Front Road, } \\
\text { location confirmed by local resident (cleaned up) }\end{array}$ \\
\hline MP17 & Overtopped area & Medium & $4.87 \pm 0.05$ & Elevation of driftwood on roadway (cleaned up) \\
\hline MP02 & Overtopped area & Lowest & $4.95 \pm 0.05$ & Elevation of driftwood on roadway (cleaned up) \\
\hline MP06 & Runup limit & High & $5.08 \pm 0.05$ & Slush line with driftwood, raised Beach Front Road \\
\hline 15_02 & Runup limit & High & $5.75 \pm 0.05$ & $\begin{array}{l}\text { Slush line with driftwood on Profile 15, on raised } \\
\text { Beach Front Road near the school }\end{array}$ \\
\hline 05_01 & Runup limit & High & $5.95 \pm 0.05$ & Slush line atop road on Profile 05 \\
\hline MP16 & Runup limit & High & $6.13 \pm 0.05$ & $\begin{array}{l}\text { Slush line with driftwood on road beside low coastal } \\
\text { bluff north of the barge landing }\end{array}$ \\
\hline
\end{tabular}

*Elevation derived from measured elevation of crane base and flood height on crane as measured by a local resident

At the DOT\&PF engineered beach (profiles 11-14, fig. 6) a steepening of the upper beach slope from approximately $15^{\circ}$ to $23^{\circ}$ occurred at profiles 11 and 13 . The base of the upper scarp, near the crest of the constructed beach, retreated inland $0.7 \mathrm{~m}$. At profile 12, a significant volume of material was transported seaward, translating into $4.5 \mathrm{~m}$ retreat at the crest and a loss of $12.5 \mathrm{~m}^{2}$ from the upper cross-sectional area. There was no significant modification to the beach at profile 14. Minor overtopping of the profile crest and adjacent roadway was observed along the length of the constructed beach project (fig. 11b). Based on the slight steepening observed at two of the profiles, we anticipate that subsequent crest retreat will occur along some portions of the project as the beach profile re-equilibrates. In the last two years, human modifications to the engineered beach project involving the placement of finer-grained sediment to the upper face of the beach may have contributed to the overtopping that was observed. Wave runup heights can be reduced through the dissipation of energy over coarser-grained material (United States Department of the Army, Coastal Engineering Research Center [CERC], 1984); efforts to leave the coarser materials that were newly exposed at the surface by this event could reduce runup heights during future events.

The eyewitness accounts that our team received were in general agreement that the November 2011 event was the most severe storm surge that has occurred since the 1970s. The consensus among residents was that the offset of the peak surge from the peak winds combined with the favorable (non-onshore) wind direction and the lower tides at the surge peak prevented more extensive flooding (see Appendix A for local plots of wind and atmospheric pressure). The new armor rock revetment appeared to minimize erosion and flooding at the mouth of Unalakleet River where flood inundation had been initiated in the past. Areas on either end of the revetment remained vulnerable: the most extreme runup elevation that was measured in the community was located at the western terminus of the new structure (fig. 8) and on the eastern end a large blowout occurred in the remaining segment of gabion wall (fig. 7b). Shifts in armor rock placement as well as any changes at the toe of the structure will need to be evaluated.

\section{Shaktoolik}

Shaktoolik, located $50 \mathrm{~km}$ north of Unalakleet, has a population of 251 (U.S. Census, 2010). The community is situated on a sand and gravel barrier spit that is bounded to the east and north by Tagoomenik River and to the west by Norton Sound. Shaktoolik has been in its present location since 1974 following a relocation from $9 \mathrm{~km}$ to the south, which was initiated in response to escalating coastal hazard risks (Native Village and City of Shaktoolik and others, 
2009). The area experiences a mean tidal range of $74 \mathrm{~cm}$ (NOAA, 2012).

According to resident accounts summarized in a 2011 report by the U.S. Army Corps of Engineers (USACE, 2011a), extreme coastal flooding events occurred at the old community site in 1960 and 1970 that resulted in the complete overtopping of the barrier spit near the former airstrip. Resident reports of an observed $1.5 \mathrm{ft}(0.5 \mathrm{~m})$ flood depth at the old community site (Wise and others, 1981) would correspond to a TWL of at least $6 \mathrm{~m}$ MSL based on the old site's elevation. Other notable storm surge events that preceded the community's relocation occurred in 1965, resulting in the loss of a dwelling and outhouses (USACE, 2011a); 1966; and the 1974 storm that resulted in $\$ 20,000$ in reported damages (Wise and others, 1981). Significant coastal storms at the present site occurred in 1978, and more recently in 2004, 2005, and 2009 (Glenn Gray \& Associates and others, 2012).
November 2011 DGGS field investigations in Shaktoolik consisted of 1.5 days of fieldwork, during which our team was able to reoccupy five of the coastal profiles established in summer 2011, measure 23 marine flood indicators, and collect photographs and video (summarized in fig. 13). A water-level sensor that was deployed in Tagoomenik River during the summer of 2011 was still in place for the November storm; however, significant ice activity on the river displaced the sensor and it has not been located to date (August 2012). The results of measurements made to evaluate the elevations of the storm water levels in Shaktoolik are presented in table 3.

Inundation limits observed on the side of the community along Tagoomenik River are most indicative of a storm tide elevation because this area was protected from wind waves. An average storm tide level of $3.3 \mathrm{~m}(11 \mathrm{ft})$ MSL was interpreted from measurements of flood levels marked by residents and visible slush lines along the bank

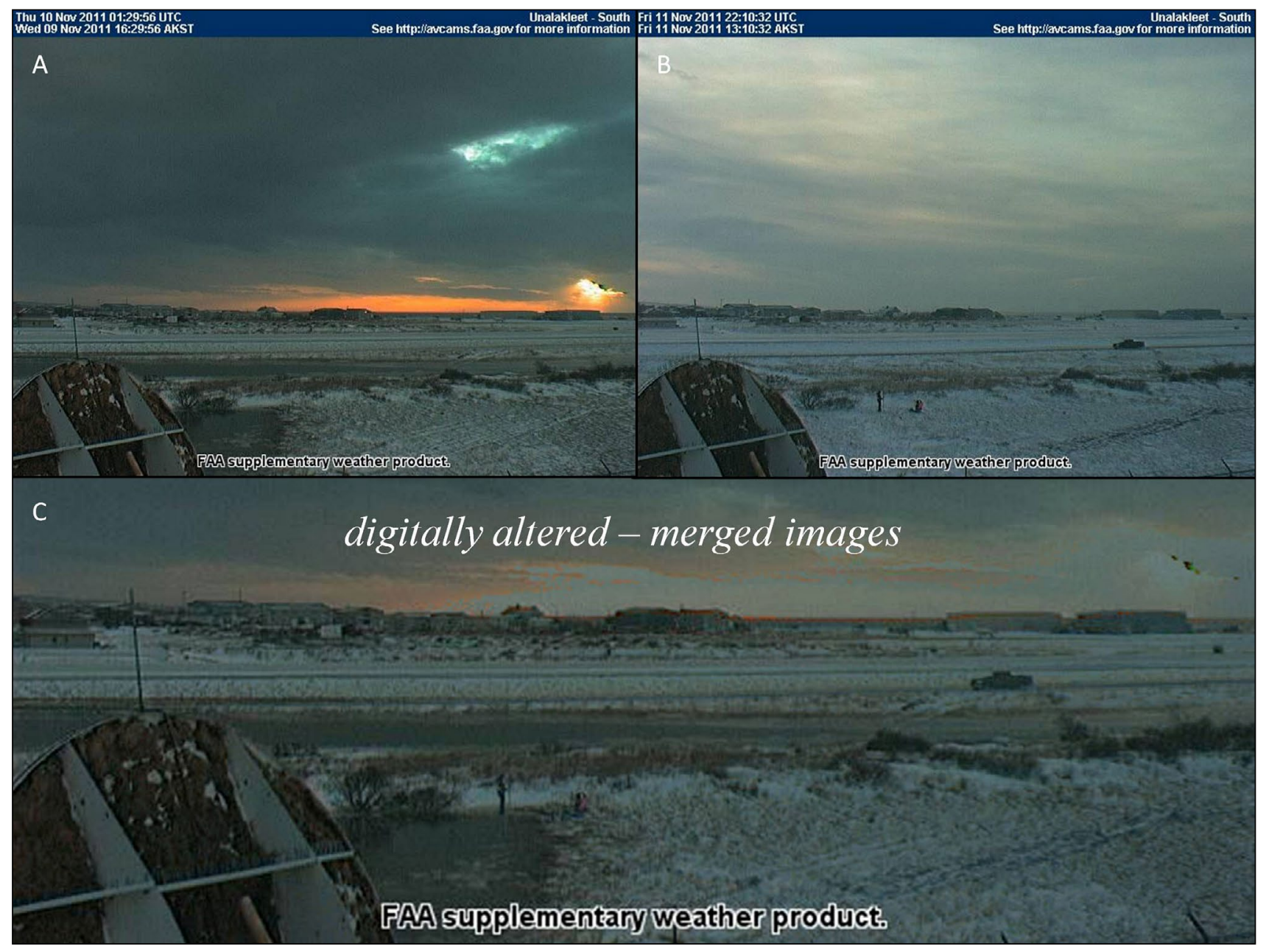

Figure 9. Collection of MP05 (table 2), a flood inundation limit on the eastern side of the Unalakleet airport, which was visible in an FAA webcam adjacent to Runway 26. (a) Image taken on the afternoon of November 9, 4:29 pm AKST, following the peak surge. (b) Image taken at 1:10 pm November 11 as DGGS workers collected an elevation measurement. (c) Digitally stitching images (a) and (b) together allows us to view the position of the workers relative to the inundation limit. 


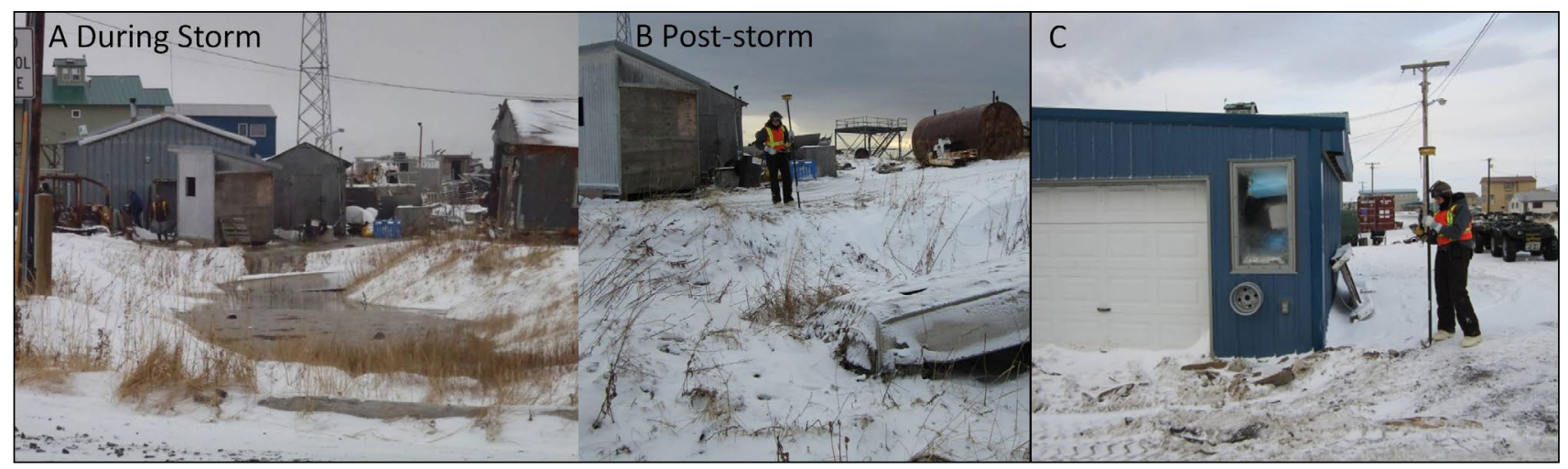

Figure 10. Photographs of flooded areas on open ocean side of Unalakleet provided an estimate of the TWL along the front of the community where the water surface was elevated above the storm tide level by nearshore wave setup. A spillover point photographed by Steve Ivanoff during the storm (a) was measured as MP11 in table 2 (b) and a slush limit adjacent to flooded garage provided the elevation for MP08 (c).

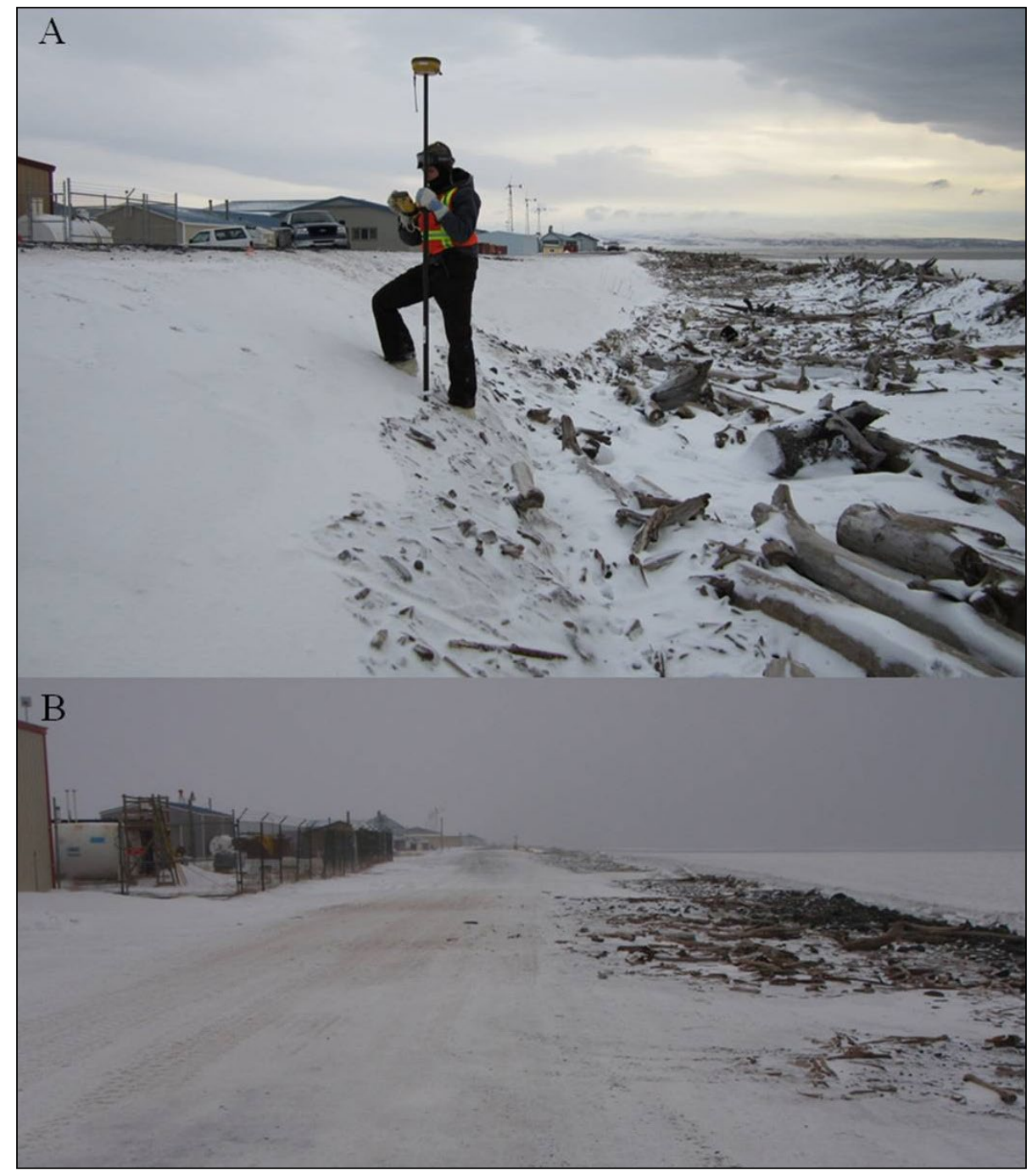

Figure 11. (a) Level of runup on side of raised Beach Front Road, Unalakleet, along Coastal Profile 15 near the school. (b) Runup level in driftwood where waves have overtopped the crest of the dynamically stable beach project on the road to the airport. 


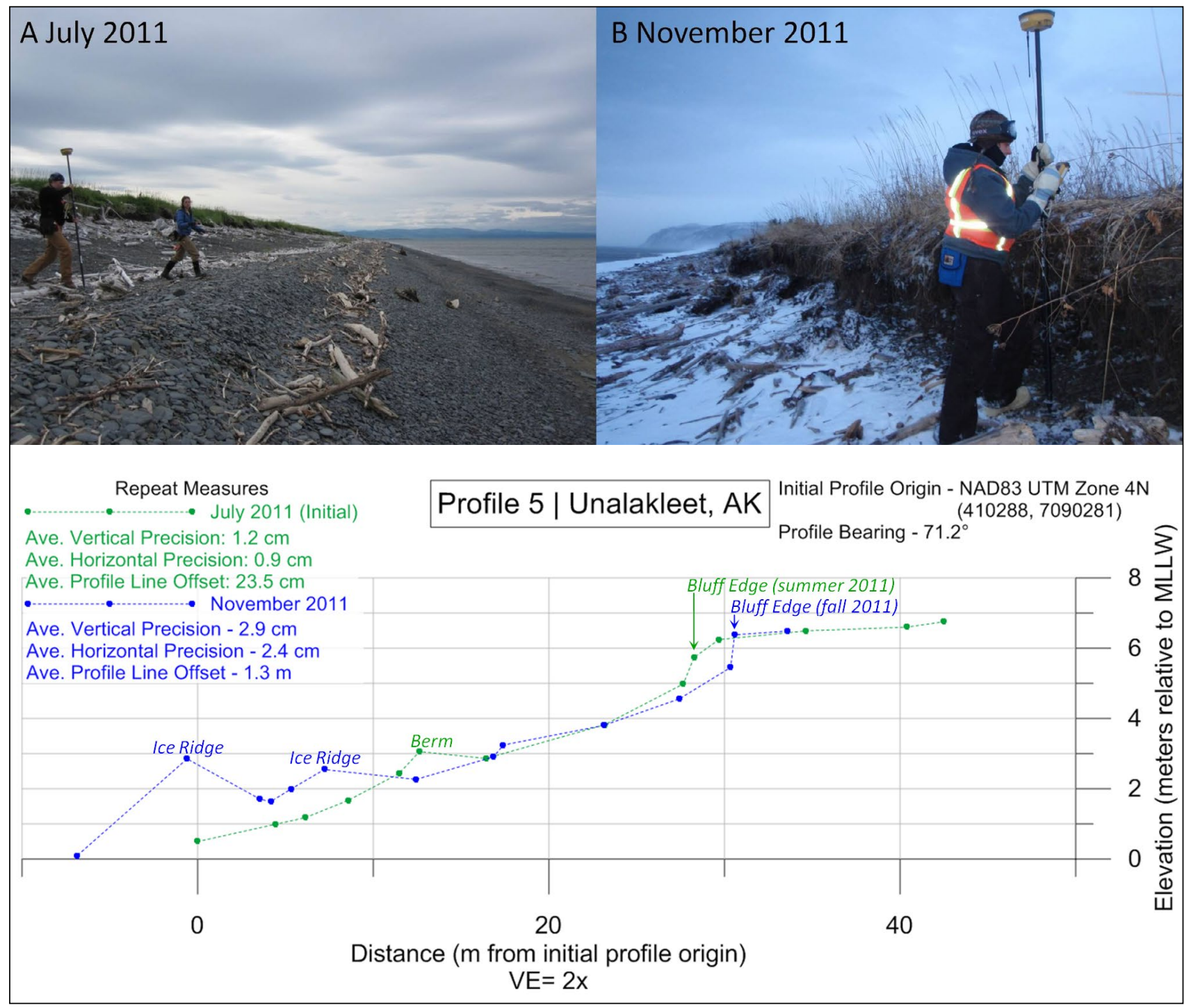

Figure 12. (a) Coastal Profile 05, north of the Unalakleet barge landing, showing a well-developed mid-beach berm and rounded low bluff, and (b) erosion of the bluff toe caused by waves during the November 2011 storm. The plots illustrate change in the morphology of the beach cross section at this location including the removal of the berm, erosion at the bluff, and the accretion of ice ridges on the lower beach.

of Tagoomenik River as well as floodwater levels that were identified with the aid of photographs taken by residents during the storm (fig. 14). An absence of sheltered flooded areas on the seaward side of the community precluded an estimate of the TWL independent of runup effects. Maximum runup elevations at the current community site were as high as 5.8 m (19 ft) MSL near the tank farm and Native Corporation building (fig. 15). At the old community site, where deeper nearshore water results in less dissipation of wave energy in the nearshore, we documented a maximum runup elevation of $7.8 \mathrm{~m}(25 \mathrm{ft}) \mathrm{MSL}$ and there was extensive wave overtopping of the low bluff indicated by slush deposits and driftwood. Floodwater capable of transporting large logs entirely over-

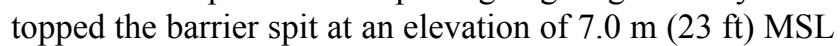
near the old site's runway (fig. 16).
Remeasured coastal profiles in the vicinity of Shaktoolik did not reveal any immediate, obvious changes to the coastal morphology as a result of the November 9 storm surge. However, we observed significant undercutting of the low bluff, up to $60 \mathrm{~cm}$ into the base of the bluffs, at the old community site (fig. 17). In many areas around the old community site, the protective talus toe had been removed and the bluff edge was being held aloft and in position by a combination of frozen ground, vegetation, and frozen slush that was deposited on the back beach as elevated water levels ebbed. When thawing occurs in the spring and summer, block failures in the bluffs along the front of the old community are expected to be prevalent. Overtopping of the wood debris deposit that extends along the coast fronting Norton Sound was isolated to only a few locations at the present community location. 


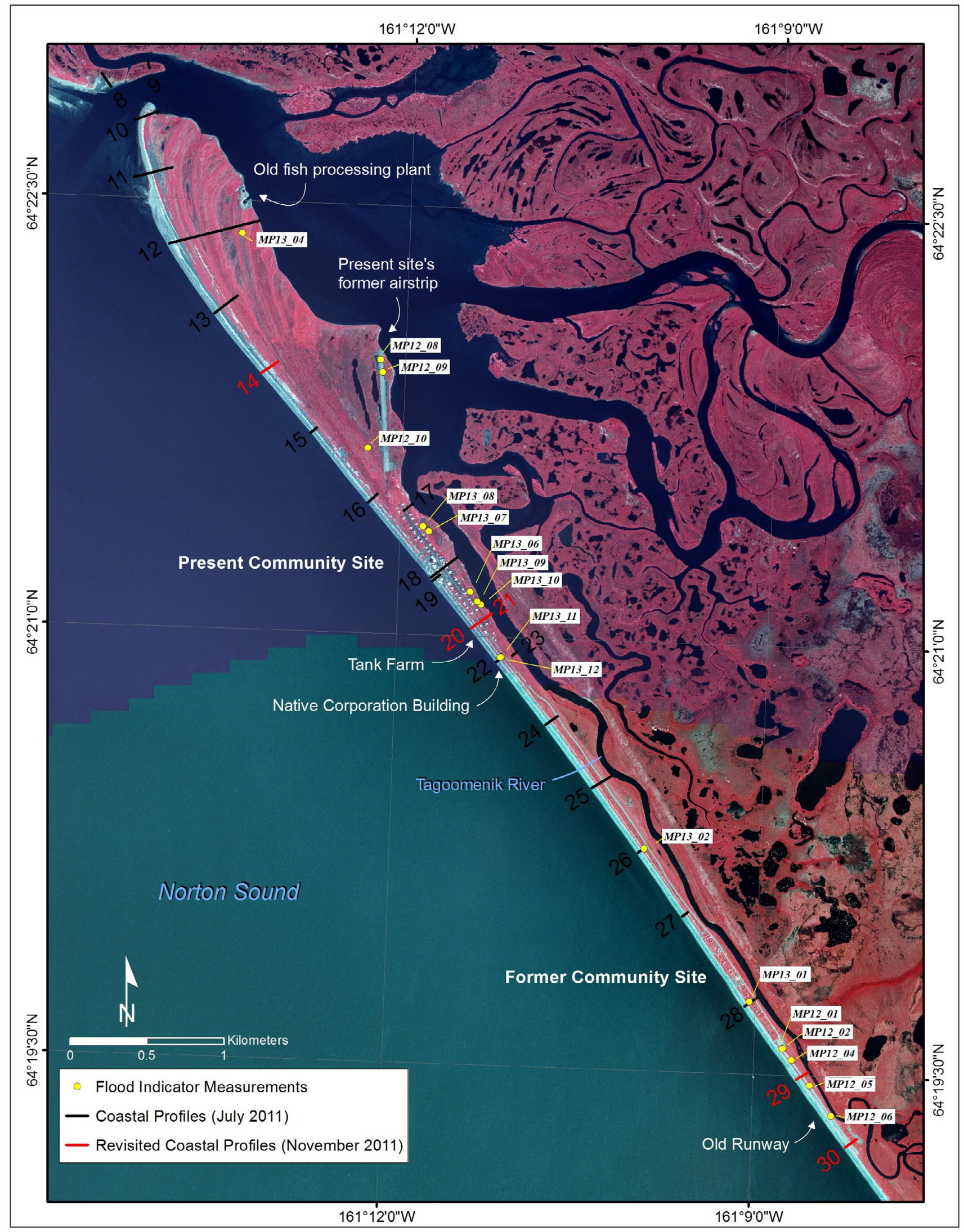

Figure 13. Summary map depicting the locations of coastal profiles and points where flood indicators were measured in the vicinity of Shaktoolik, Alaska. The base layer is composed of orthorectified 1981 Alaska High-Altitude Photography (AHAP) imagery. 
The coastal profile collected at the airport suggests that new wood debris was deposited above previous levels north of the present community. A complete set of plotted profile change figures is included in Appendix B.

Because the community of Shaktoolik has relocated within the last 30 years, observations of historic storms have been made from a different vantage point. This makes it more difficult for residents to provide objective comparisons regarding the relative severity of pre- and post-1974 events. Disagreement regarding the severity of recent events exists as well: many residents with whom our team spoke perceived the November 2011 event to be the largest storm surge since the relocation while othersfelt that the 2009 storm was of a greater magnitude. Some residents voiced fear and concern about overtopping at the old site that could impede or block the route of evacuation along the barrier spit from the present community site to inland areas; this has been a concern prior to this event as well (Glenn Gray \& Associates and others, 2012). Eyewitness accounts, from both during and after the storm, emphasized the elevated water level along the banks of Tagoomenik River as being unique to this storm. Homeowners on the eastern side of the barrier spit reported that, for the first time, they felt more at risk for flooding than those with homes on the open-ocean side of the community. Wave runup was apparently lessened along this section of open-ocean coast by a wide area of slush that dampened the

Table 3. Elevations and descriptions of marine flood indicators that were measured in the vicinity of Shaktoolik, Alaska, November 12-13, 2011. Point numbers not preceded by 'MP' were collected along coastal profiles. Measurements used to infer different types of water levels during the peak storm surge are highlighted: Storm tide (surge + tide; blue), maximum wave runup within the inhabited community (orange) and maximum observed runup in the entire area (red).

\begin{tabular}{|c|c|c|c|c|}
\hline $\begin{array}{c}\text { Point } \\
\text { Number }\end{array}$ & $\begin{array}{c}\text { Measurement } \\
\text { Type }\end{array}$ & $\begin{array}{c}\text { Confidence } \\
\text { Level }\end{array}$ & $\begin{array}{l}\text { Elevation } \\
\text { (m MSL) }\end{array}$ & Description \\
\hline $21 \_14$ & Inundated area & High & $2.16 \pm 0.07$ & $\begin{array}{l}\text { Elevation of slush on bank of Tagoomenik River, } \\
\text { Profile 21, no visible extent (drifted snow present) }\end{array}$ \\
\hline MP13_08 & Inundation limit & Medium & $2.58 \pm 0.06$ & $\begin{array}{l}\text { Photo-located on bank of Tagoomenik River (not at } \\
\text { peak) }\end{array}$ \\
\hline MP13_10 & Inundation limit & Lowest & $2.59 \pm 0.06$ & $\begin{array}{l}\text { Slush limit and calving snow line on Tagoomenik } \\
\text { River }\end{array}$ \\
\hline MP12_08 & Inundated area & Medium & $2.71 \pm 0.14$ & Elevation of ice jam at the present site's old airstrip \\
\hline MP12_09 & Inundated area & High & $3.17 \pm 0.14$ & Elevation of rafted ice atop present site's old airstrip \\
\hline MP13_07 & Peak flood level & Medium & $3.22 \pm 0.07$ & $\begin{array}{l}\text { Photo-located elevation on fish drying rack along } \\
\text { Tagoomenik River }\end{array}$ \\
\hline MP12_10 & Inundation limit & Lowest & $3.24 \pm 0.14$ & $\begin{array}{l}\text { Slush limit in low area on the Tagoomenik River side } \\
\text { of active airport, near windmills (snow present) }\end{array}$ \\
\hline MP13_09 & Inundation limit & Medium & $3.32 \pm 0.06$ & $\begin{array}{l}\text { Photo-located on fish drying rack along Tagoomenik } \\
\text { River }\end{array}$ \\
\hline MP13_06 & Inundation limit & High & $3.42 \pm 0.06$ & $\begin{array}{l}\text { Marked with stake by local resident, on Tagoomenik } \\
\text { River }\end{array}$ \\
\hline MP13_04 & Inundation limit & Lowest & $3.48 \pm 0.07$ & $\begin{array}{l}\text { Slush limit on surface of road to old fish plant next to } \\
\text { the Tagoomenik River (snow covered) }\end{array}$ \\
\hline $14 \_01$ & Below runup & High & $4.89 \pm 0.07$ & In slush with unclear extent, airport Profile 14 \\
\hline $14 \_02$ & Overtopped area & High & $5.48 \pm 0.06$ & Elevation of slush-capped wood debris on Profile 14 \\
\hline MP13_11 & Runup limit & High & $5.52 \pm 0.06$ & $\begin{array}{l}\text { Slush and debris line in front of Native corporation } \\
\text { building }\end{array}$ \\
\hline $20 \_07$ & Runup limit & High & $5.85 \pm 0.06$ & $\begin{array}{l}\text { Slush line on front face of driftwood debris pile (not } \\
\text { overtopped) on Profile } 20 \text { near the tank farm }\end{array}$ \\
\hline $30 \_01$ & Runup limit & Lowest & $6.00 \pm 0.06$ & Slush line atop coastal bluff (snow covered) \\
\hline MP12_05 & Runup limit & High & $6.29 \pm 0.17$ & Large driftwood deposited on old site's runway \\
\hline MP13_12 & Overtopped area & Medium & $6.39 \pm 0.07$ & $\begin{array}{l}\text { Maximum elevation of slush deposited atop driftwood } \\
\text { debris pile in front of Native corporation building }\end{array}$ \\
\hline MP12_04 & Runup limit & High & $6.83 \pm 0.06$ & Large driftwood deposit on old site's runway \\
\hline MP12_02 & Overtopped area & Medium & $6.83 \pm 0.06$ & Elevation of slush-capped driftwood pile at old site \\
\hline MP12_06 & Inundated area & High & $6.98 \pm 0.06$ & Washover location at old site's runway, driftwood \\
\hline MP13_02 & Below runup & Medium & $7.01 \pm 0.06$ & $\begin{array}{l}\text { Driftwood, gravel, and slush deposited atop willows } \\
\text { near a washed-out portion of bluff edge }\end{array}$ \\
\hline MP13_01 & Runup limit & Medium & $7.66 \pm 0.28$ & Slush line with driftwood atop bluff at old site \\
\hline MP12_01 & Runup limit & High & $7.77 \pm 0.14$ & Slush line with driftwood atop bluff at old site \\
\hline
\end{tabular}


amplitude of the incoming waves and reduced wave energy prior to landfall. Slush accumulation was also reported at the mouth of Tagoomenik River and this, combined with ice jams near the mouth of the river, may have slowed outflow from the river as the storm subsided, and contributed to elevated water levels along the river.

\section{Nome}

Nome, situated on the southern edge of the Seward Peninsula (fig. 18) has a population of 3,500 (Hufford and
Partain, 2004) and is the largest city in the Norton Sound region. The city is located on a coastal plain south of the Kigluaik Mountains and is home to a seaport at the mouth of Snake River. The area experiences a well-established mean tidal range of just $31 \mathrm{~cm}$ (NOAA, 2012). The Nome-Council Road runs east from the city along a low, bluffed coastline to Cape Nome. Just east of Cape Nome, a barrier island and spit system fronts Safety Sound, a shallow lagoon that drains Flambeau, Eldorado, and Bonanza rivers. In contrast to the

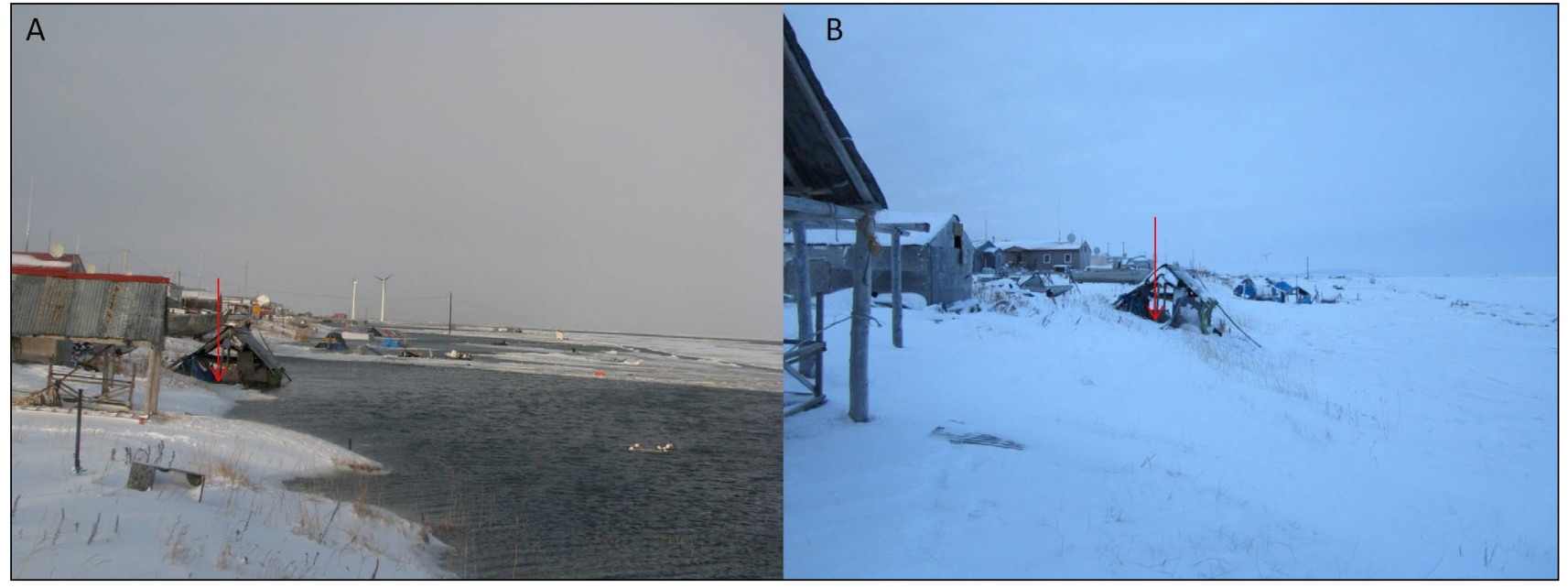

Figure 14. (a) Location of elevated water level on the bank of Tagoomenik River as photographed by Elmer Bekoalok on November 9, 2011, and (b) the measured point MP13_09 (table 3) as determined by the position of the water relative to the upright support on the fish drying rack highlighted by the red arrow in both photos.

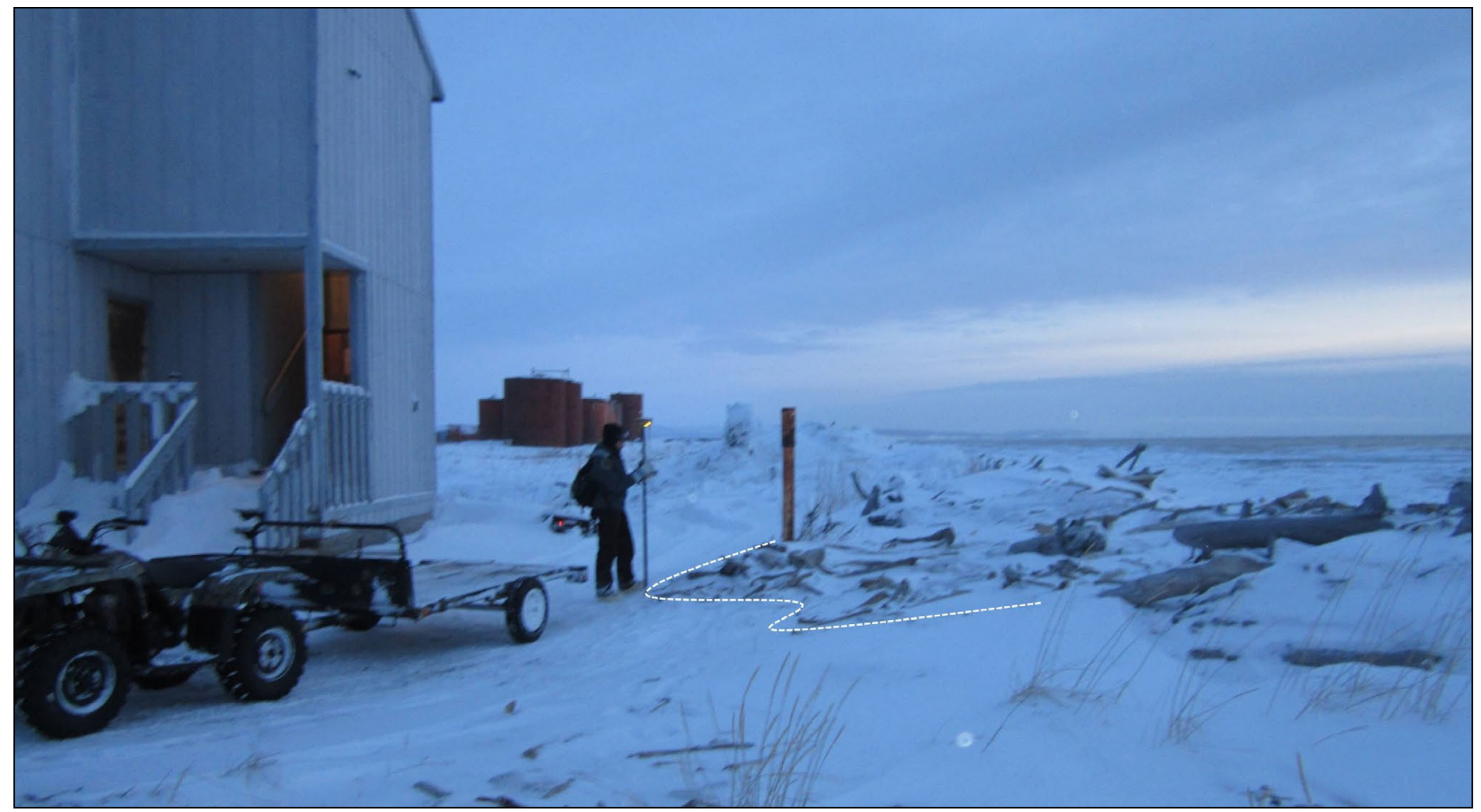

Figure 15. Inland limit of a runup deposit (highlighted by white dashed line) that overtopped the driftwood debris pile in front of the Native corporation building (MP13_11 and MP13_12, table 3). 
coarse gravels of eastern Norton Sound, the beaches in Nome are composed of sand. In past events, the coastal morphology has exhibited a complex response to storm events including both net erosion and accretion, as well as episodic and localized bluff retreat (Sallenger and Dingler, 1978).

The record of damages in the Nome area caused by coastal flooding is extensive and dates back to 1898 (Wise and others, 1981). In 1900, a September 12 storm led to $\$ 750,000$ in damages and the loss of life. Just a few years later, in 1913, a storm destroyed half of the developed city and caused $\$ 1$ million in damages (City of Nome and others, 2008). The extreme storm surge event of 1960 caused $\$ 100,000$ in damages along the road due to erosion, and an event in 1974 (12 $\mathrm{ft}$ or $3.7 \mathrm{~m}$ MSL, City of Nome and others, 2008; $13.2 \mathrm{ft}$ or $4.0 \mathrm{~m}$ MSL flood of record, USACE 2011b; $20 \mathrm{ft}$ or $6.1 \mathrm{~m}$ MSL, Wise and others 1981) overtopped the seawall and caused \$12-\$30 million in damages (Wise and others, 1981; Sallenger and Dingler, 1978). In 1978, a $10 \mathrm{ft}$ (3.0 m) MSL surge led to more than $\$ 1$ million in damages both inside the city limits and along the Nome-Council Road (Wise and others, 1981). Other notable flooding and erosion events occurred in 1902, 1937, 1942, 1946, 1967, and 1972 (City of Nome and others, 2008). Emplacement of extensive coastal defense structures beginning with port jetties in 1940 and a seawall in 1951 (FEMA, 2010), have mitigated damages from large storms that have impacted other communities in more recent years, but they do not offer complete protection. In 1992 , Nome sustained more than $\$ 6$ million in damages fol- lowing a large storm event (Blier and others, 1997). In 2004, a $3 \mathrm{~m}$ MSL storm surge resulted in more than $\$ 5$ million in damages (Hufford and Partain, 2004), and in 2005 a similar storm resulted in extensive damages to local infrastructure.

Unlike in Unalakleet and Shaktoolik, staff from the DGGS Coastal Hazards Program had not previously conducted work or established coastal profiles in the Nome area. November 2011 DGGS field investigations consisted of one day of fieldwork, during which our team was able to establish three coastal profiles along the Nome-Council Road and measure 14 marine flood indicators (summarized in fig. 18). Significant clearing of the road and clean-up that was already underway limited the total number of flood indicators that could be measured. The results of measurements made to evaluate the inundation and runup elevations in Nome are presented in table 4.

Inundation limits measured along the edge of Safety Sound, on the inland side of the barrier spit, can be inferred to be most indicative of a storm tide elevation. Our measurements in this area indicate a storm tide level elevation of $3.3 \mathrm{~m}(11 \mathrm{ft})$ MSL. On the seaward side of the Nome-Council Road, where wave setup resulted in an additional increase in water level, the TWL reached $4.2 \mathrm{~m}$ (14 ft) MSL (fig. 19c). Maximum wave runup elevations along the observed portion of coast were as high as $6.4 \mathrm{~m}$ (21 ft) MSL (fig. 19b) atop the coastal bluffs between Nome River and Cape Nome. Large pieces of ice and driftwood were deposited by waves atop 3-4 m bluffs throughout this area.

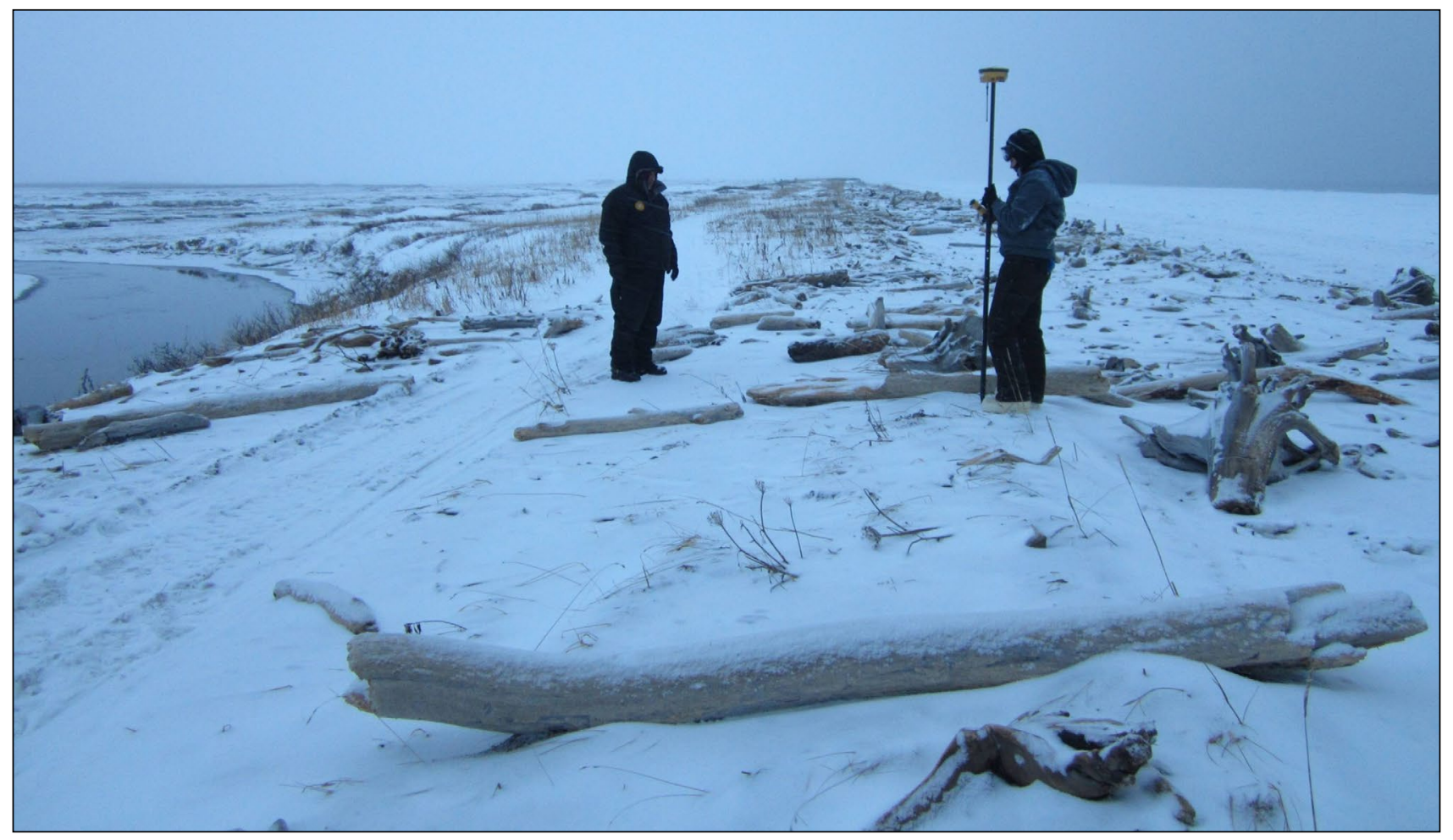

Figure 16. Photograph, looking to the south, of an area on the runway at the old Shaktoolik community site, where the barrier spit was overtopped and water flowed from Norton Sound into Tagoomenik River, visible on the left side of the photograph (MP12_06, table 3). 


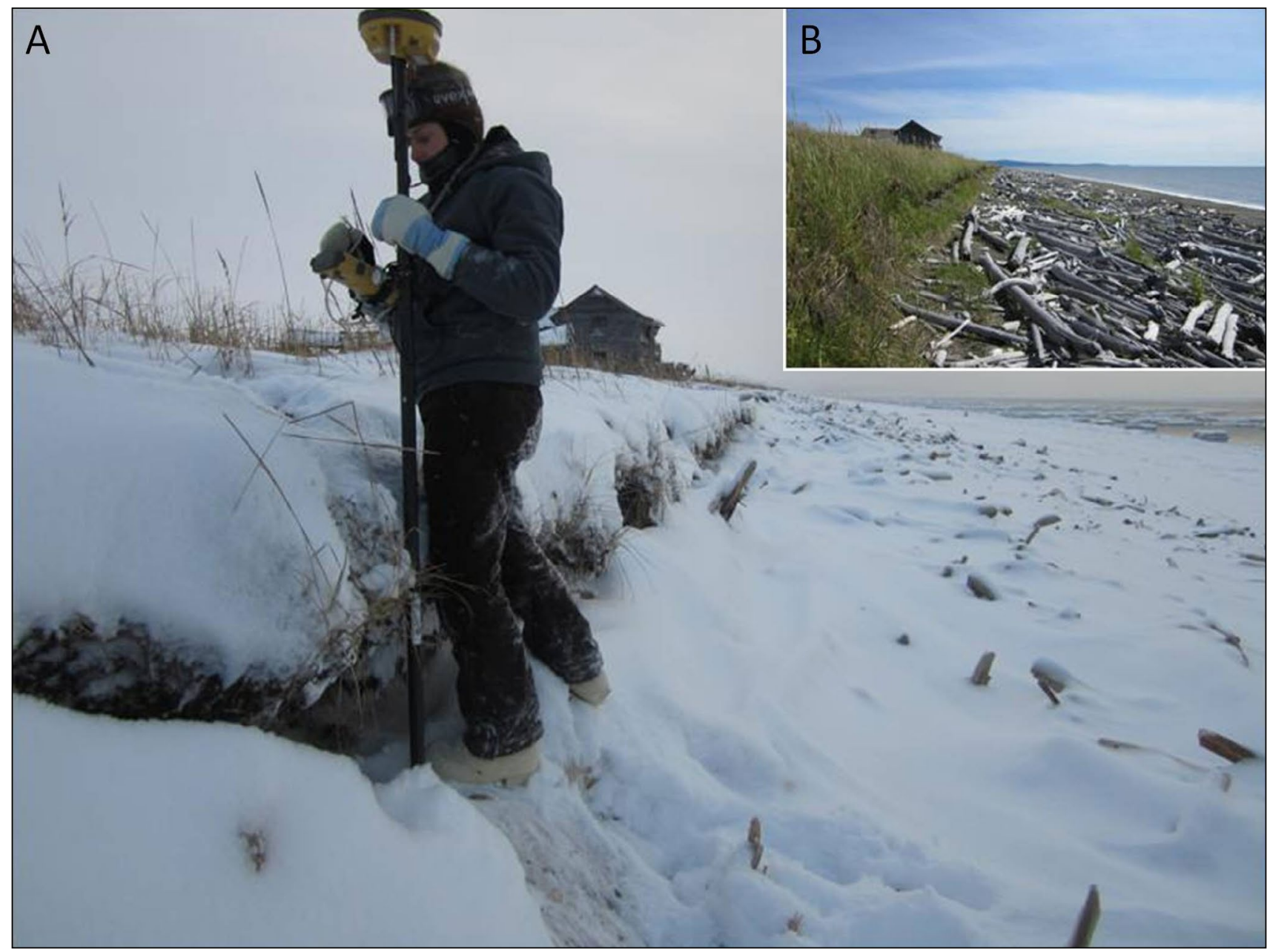

Figure 17. (a) Basal notching $60 \mathrm{~cm}$ into the low coastal bluff at the old community site was observed in areas that had a vegetated talus toe prior to the November 2011 storm (inset photo b).

Our team observed extensive damage to the roadway and rubble mound revetments along much of the Nome-Council Road that we visited. One day prior to our arrival, portions of the road were still closed to vehicle access and clean-up efforts were in progress as we were collecting measurements. Just west of Nome River, a breach in the armored revetment exposed the road to undermining (fig. 20a). Additional breaches to revetments along the road were also observed, particularly along the coast adjacent to Safety Sound. Near Mile 17 on the Nome-Council Road, large pieces of riprap were washed across the road during the storm and deposited both atop the spit and in the Sound (fig. 20b). The three coastal profiles that were established in Nome are not presented in this report but will be included in a future DGGS publication once more profiles have been established.

\section{Golovin}

Golovin, a community of 156 residents (U.S. Census, 2010), is located on a peninsula between Golovnin Bay and Golovnin Lagoon on the northern edge of Norton Sound (fig. 21; for variations on the use of 'Golovnin', see Orth, 1971). A majority of the facilities and infrastructure in the community, including the school, City and Native corporation building, health clinic, power plant, and communication services buildings are built upon low-lying coastal deposits (see map sheet 1 for additional detail). More recent development including the new airport, the Economic Development Administration building, and recently constructed residences are built on an elevated ( $>12 \mathrm{~m}$ ) bedrock surface to the east. The area experiences a mean tidal range of less than $55 \mathrm{~cm}$ (based on 2005 spring tidal range for nearby Carolyn Island; NOAA, 2012).

Golovin's sheltered position in Norton Sound protects it from some of the peak winds observed elsewhere during strong storms, yet extensive coastal flooding in the lowerlying areas of the community has been a recurrent issue. During large storms, coastal flooding typically encroaches on the community from the northern, or lagoon, side. The earliest documented storm surges in the community date to 1900 and the most severe event on record took place in 1913 (City of Golovin and others, 2008). The record of storm damages specific to the City of Golovin is sparse but includes the loss of a building in 1945 (City of Golovin and others, 2008) and flooding of the old airport in 1977 (Wise and others, 1981). 


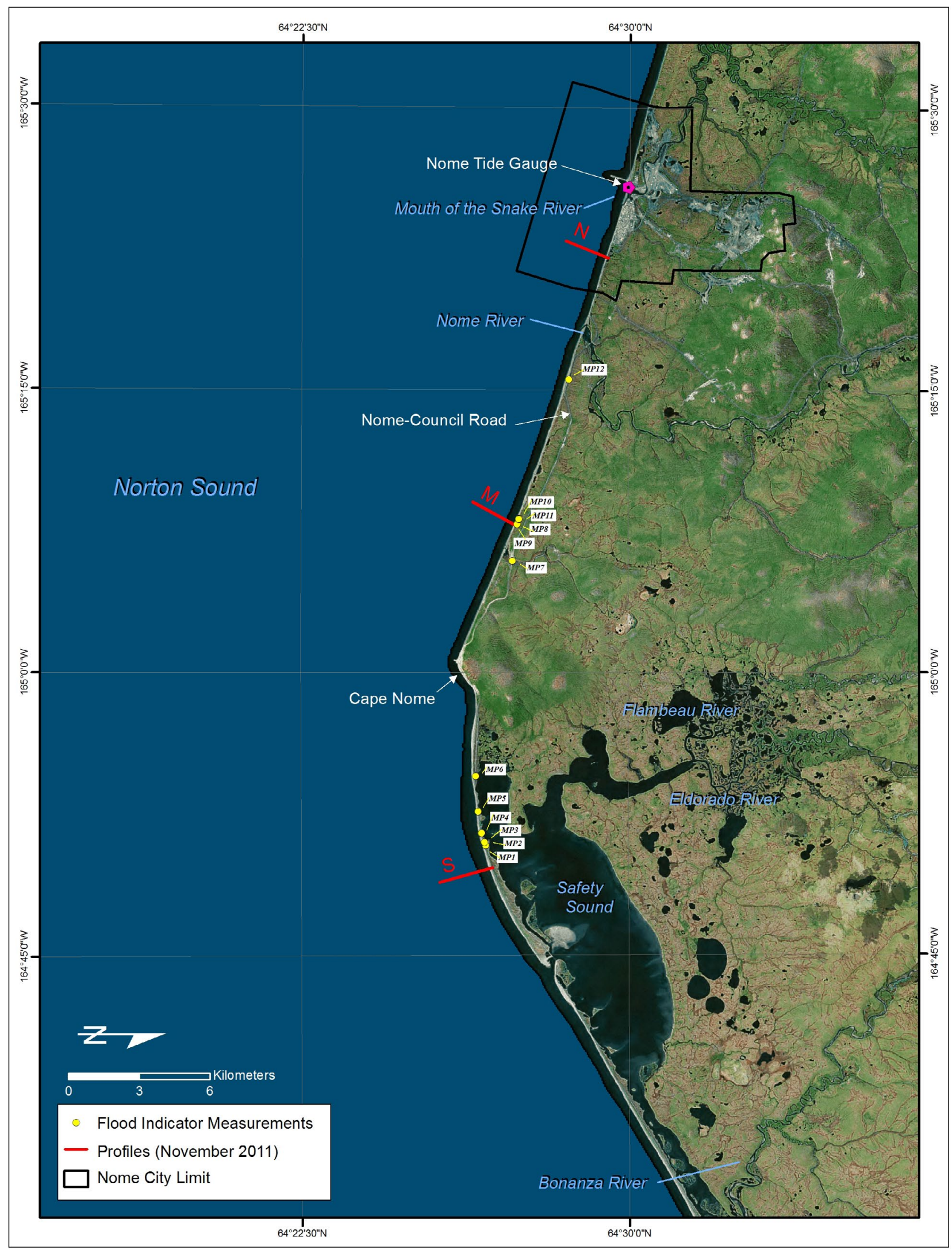

Figure 18. Summary map depicting the locations of coastal profiles and points where flood indicators were measured along the Nome-Council Road east of Nome, Alaska (note direction of north arrow). The base layer is a 2000 LANDSAT satellite image. 
Table 4. Elevations and descriptions of marine flood indicators measured along the Nome-Council Road on November 14, 2011. Point numbers not preceded by 'MP' were collected along coastal profiles. Measurements used to infer different types of water levels during the peak storm surge are highlighted: Storm tide (surge + tide; blue), TWL (surge + tide + wave setup; green), and maximum observed runup in the entire area (red).

\begin{tabular}{|c|l|c|c|l|}
\hline $\begin{array}{c}\text { Point } \\
\text { Number }\end{array}$ & $\begin{array}{c}\text { Measurement } \\
\text { Type }\end{array}$ & $\begin{array}{c}\text { Confidence } \\
\text { Level }\end{array}$ & $\begin{array}{c}\text { Elevation } \\
\text { (m MSL) }\end{array}$ & \multicolumn{1}{|c|}{ Description } \\
\hline MP02 & Inundated area & High & $2.26 \pm 0.47$ & Maximum elevation of flow into the lagoon at Mile 18 \\
\hline MP01 & Inundated area & Medium & $2.73 \pm 0.45$ & Low point on inland side of road (snow covered) \\
\hline MP06 & Inundation limit & High & $3.26 \pm 0.22$ & Slush limit against roadway, inland side of barrier spit \\
\hline MP04 & Inundation limit & Lowest & $3.41 \pm 0.22$ & Waterline on lagoon side of road, area not overtopped \\
\hline MP03 & Overtopped area & Medium & $3.71 \pm 0.21$ & Maximum elevation of a wide overflow on roadway \\
\hline MP05 & Overtopped area & Medium & $3.94 \pm 0.21$ & Maximum elevation of breached portion of revetment \\
\hline MP12 & Inundation limit & Medium & $4.20 \pm 0.22$ & Slush line against base of roadway open-ocean side \\
\hline S_03 & Runup limit & High & $4.23 \pm 0.23$ & $\begin{array}{l}\text { Driftwood and slush line atop dune grass along Profile } \\
\text { S, undisturbed grass from this point inland }\end{array}$ \\
\hline MP07 & Above flooding & Medium & $4.84 \pm 0.19$ & Elevation of Hastings Creek bridge, not overtopped \\
\hline MP08 & Runup limit & High & $5.19 \pm 0.20$ & Driftwood and slush line atop coastal bluff \\
\hline MP09 & Runup limit & High & $5.91 \pm 0.22$ & Driftwood, ice chunks and slush line atop bluff \\
\hline M_02 & Runup limit & High & $6.02 \pm 0.19$ & $\begin{array}{l}\text { Driftwood, ice chunks and slush line atop coastal bluff } \\
\text { along Profile M }\end{array}$ \\
\hline MP11 & Overtopped area & Lowest & $6.28 \pm 0.21$ & Wave-tossed driftwood and ice chunks atop bluff \\
\hline MP10 & Runup limit & High & $6.43 \pm 0.20$ & Driftwood and slush line atop protruding bluff \\
\hline
\end{tabular}

The previous flood of record for the City occurred in 1992 and the current flood of record was in 2005 (USACE, 2011b). In recent years, Golovin has experienced severe flooding and erosion that have resulted in damages to city infrastructure in 2004, 2005, 2008, and 2009 (City of Golovin and others, 2008). Rafted debris transported during previous storms, such as a large fuel tank, can be seen stranded around the edges of Golovnin Lagoon.

As in Nome, DGGS Coastal Hazards Program staff had not conducted field investigations in Golovin prior to November 2011. Investigations following the storm consisted of one day of fieldwork, during which our team was able to measure 32 marine flood indicators and collect personal accounts, photos, and video from residents. The results of measurements made to evaluate the inundation and runup elevations in Golovin are presented in table 5 and on map sheet 1 . The team lead also made a site visit to an area near the head of Golovnin Lagoon at the mouth of Kachauik River where the November 9 storm surge triggered an ice override event (or ivu) that caused extensive damage to the community's permanent summer fish camp.

Map sheet 1 shows the extent of the November 9, 2011, flood in Golovin based on the position of measured flood indicators, the 2004 DCCED digital elevation model (DEM; DCCED and Kawerak, Inc., 2004), and the locations of floodwater as visible in residents' photographs from the event. The 2004 DEM was used to develop a static model of horizontal inundation extents at different water elevations for comparison with actual observations. This model, combined with the timestamps on the residents' photographs, was used to reconstruct the timing and direction of flow as the flood crested. A preliminary version of this map, including a set of questions that was designed to resolve gaps in observed inundation extents and discrepancies between 2004 and 2011 elevations, was sent to the community of Golovin for review in March 2012. This map was circulated among members of the Golovin Native Corporation, the City of Golovin (including equipment operators involved in clean-up activities), and the Chinik Eskimo Community. It was also placed in a central location in Golovin for general review by any other interested parties (fig. 22). In April 2012, feedback from this community review process was incorporated into the final version of the inundation map included with this report.

The final map of the flood extent in Golovin includes the peak flood inundation line and all of our measured flood indicators. Flooding in the vicinity of the old airport progressed in a chambered fashion; the topography of the peninsula caused the flooding to start at the southwestern end of the old runway, yet the elevated runway surface prevented overtopping from occurring in this area and water flowed along the runway, finally overtopping at a lower elevation on the northeast end. This meandering flow through the low-lying areas protected the part of the community housing the tank farm and water holding tank from heightened setup and runup effects by dissipating the wave energy. The elevated grading of Antone Street also restricted the primary floodwater path into the main part of town to the intersection just south of the small craft harbor. During the November 9 surge, the flood crossed this intersection sometime between 11 am and noon. In the early afternoon, the floodwaters progressed along the south side of Antone Street, past the communication towers, spilling over Punguk Street into the low-lying area on the eastern edge of town between 1 and $2 \mathrm{pm}$, and eventually almost entirely surrounding the school. The flooding crested 
and began to ebb a little after 4 pm on November 9, 2011. The low-lying area on the east side of town often collects water from surface runoff in the warmer months but the sandy soils quickly drain when the ground is not frozen. At the time of our visit, iced-over floodwaters were still present in many of the low-lying areas around town.
Based on the measured flood inundation limits that we collected from around the community and on a direct water level measured on the fill pile near the end of Antone Street (point GLV_16), the measured elevation of the peak water level including astronomical tide (storm tide level) in Golovin was $4.3 \pm 0.6 \mathrm{~m}$ NAVD88. A tidal datum has not been estab-

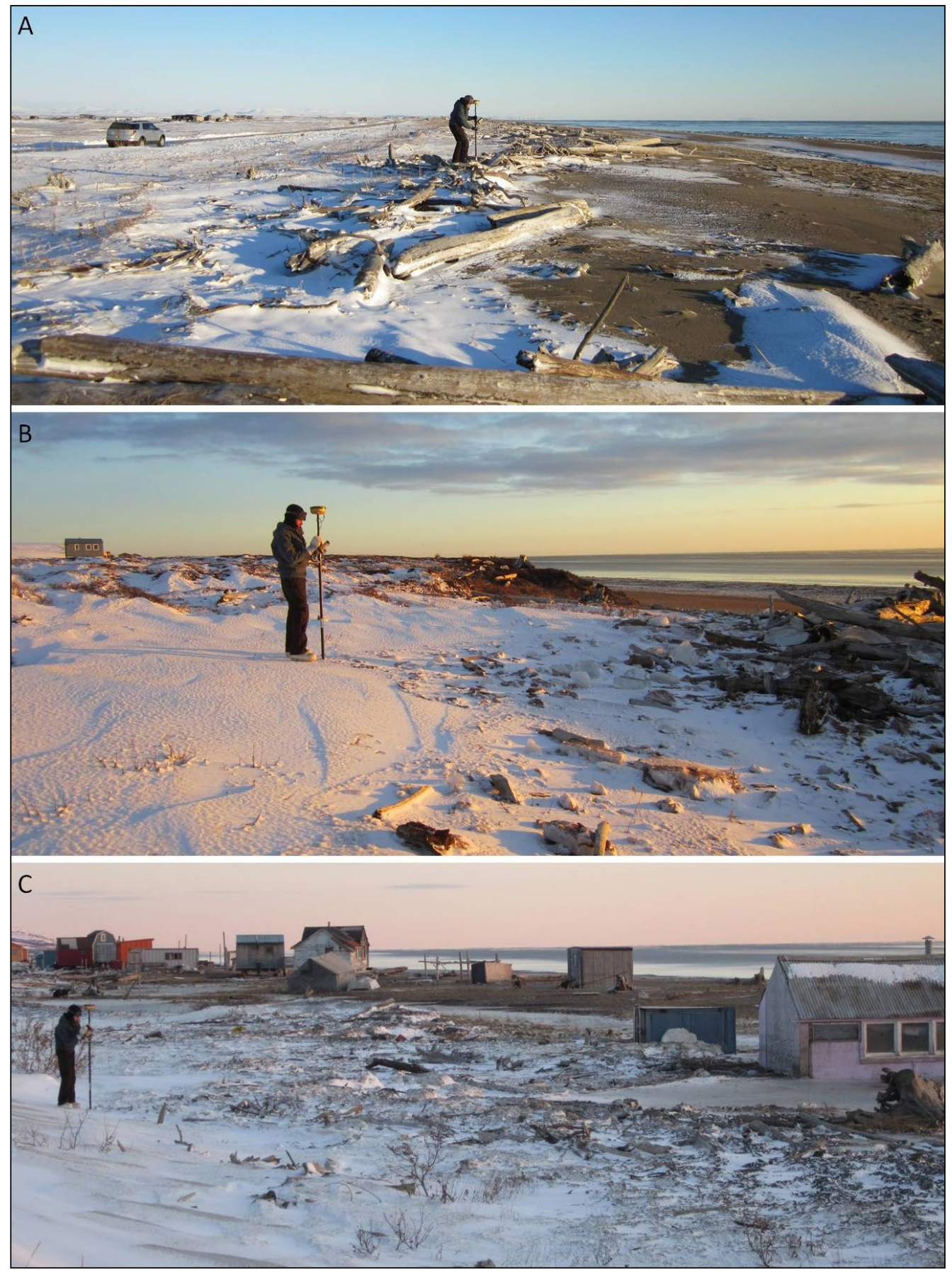

Figure 19. Examples of measured flood indicators along the Nome-Council Road from east to west: (a) Inland limit of flooding along Profile S (S_03, table 4); (b), slush line (MP09, table 4) atop a coastal bluff near Profile $M$; and (c) inundation limit on open-ocean coast behind beach cabins (MP12, table 4). 


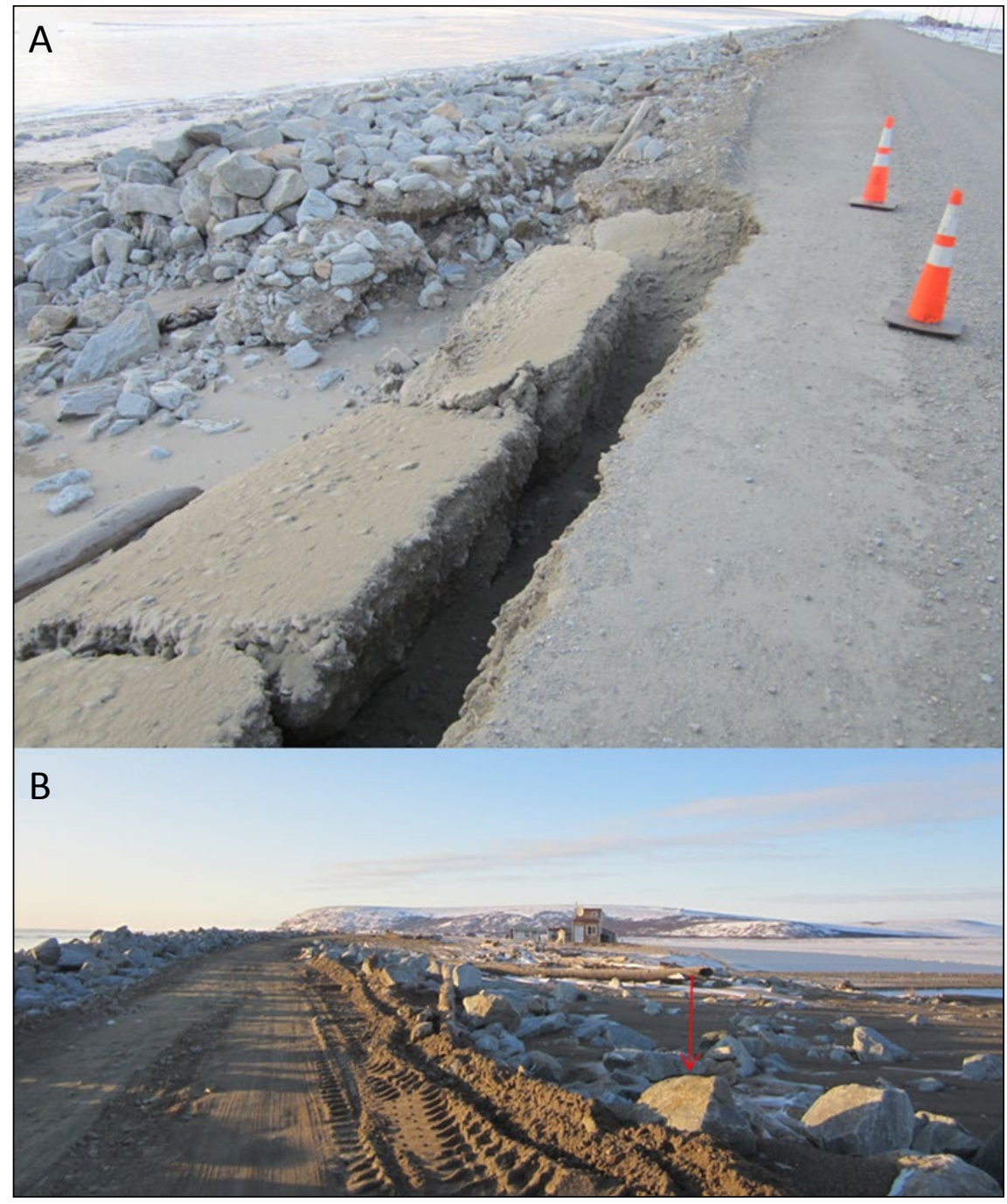

Figure 20. Significant modification to coastal engineering structures and damages along the Nome-Council Road included (a) undermining of the paved road and (b) the removal/transport of armor rock from the revetment near Mile 17. For scale, the rock highlighted by the red arrow in (b) was approximately $0.6 \mathrm{~m}$ in diameter.

lished near Golovin so this elevation cannot be accurately reported relative to local MSL A direct water-level measurement that was collected on the face of the cliffs adjacent to the community (fig. 23, point GLV_32; $5.59 \pm 0.6 \mathrm{~m}$ ) was higher than other measured flood indicators. This location was exposed to flowing water and waves in Golovnin Lagoon and may have been elevated by nearshore setup effects. If this area was affected by wave setup, then the measurement suggests a nearshore setup height of approximately $1.3 \mathrm{~m}$ (peak observed TWL minus storm tide level) on the lagoon side of the community where the primary encroachment of floodwaters was initiated. Due to the morphology of the Golovin coastline, which shelters the community from direct wave attack, the paucity of runup limit indicators and the short amount of time available in the field, measurements of the elevation of wave runup on the Golovnin Bay side of the community could not be made. However, reported accounts from several residents indicated that a protective band of slush helped to reduce the incident wave energy on the southern side of the community. Our observations supported these accounts because there was no evidence of waves overtopping the crest of the ice ridge along the Golovnin Bay coast, except at the very southwestern tip of the peninsula near the old airport (GLV_06).

Eyewitness accounts that our team received were in general agreement that flooding from the November 2011 storm was not as severe as other storms that have occurred during the last decade, such as in 2005. Many people reported that Antone Street, which was elevated in 2006, helped to reduce the amount of flooding within the town and around the school. Although Golovin received little media coverage during the storm, at least nine structures were reported to be fully surrounded by water during the peak of the marine flooding, cell phone communications were lost when electronic equipment at the towers was damaged by floodwater and some of the fuel was contaminated by water. Further, flooding may have contributed to the freeze-up of the primary underground water transmission line (written commun., Anungazuk, 2012). Residents expressed relief that peak flooding occurred during daylight hours and that it did not last for as long as it has during past events. Concern was voiced over the location of the flooding relative to the power transformer and about the damage caused by the ivu at the fish camp. 


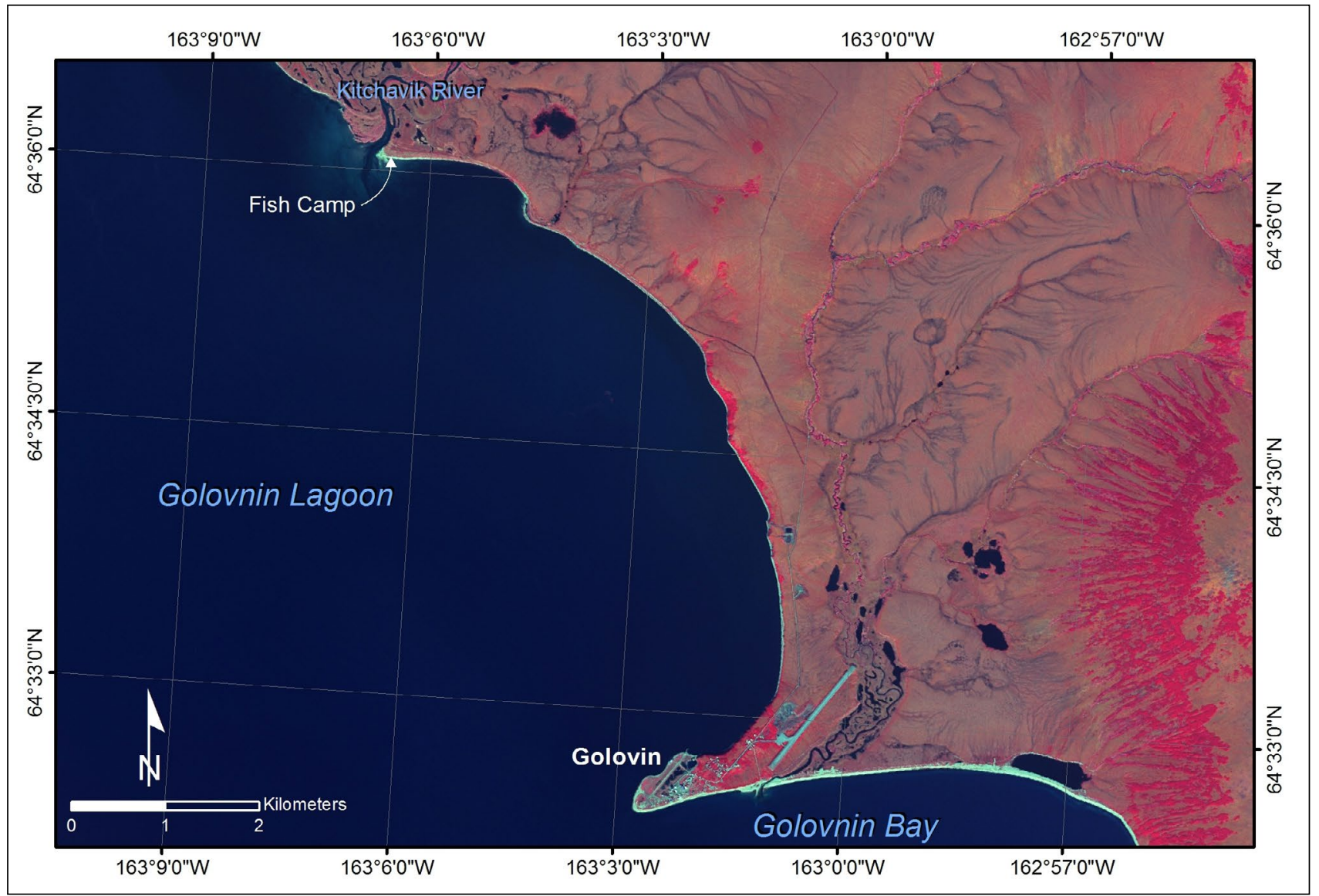

Figure 21. Summary map of Golovin, Alaska, area including the location of fish camp shown relative to the position of the community. The base layer is a 2009 SPOT5 infrared satellite image (vegetation appears red).

Figure 22. Dora Davis, a Chinik Eskimo Community grant writer, displays a preliminary version of the flood inundation map that was circulated by Golovin residents for collaborative feedback and edits prior to publication in this report (photo by Carol Oliver).

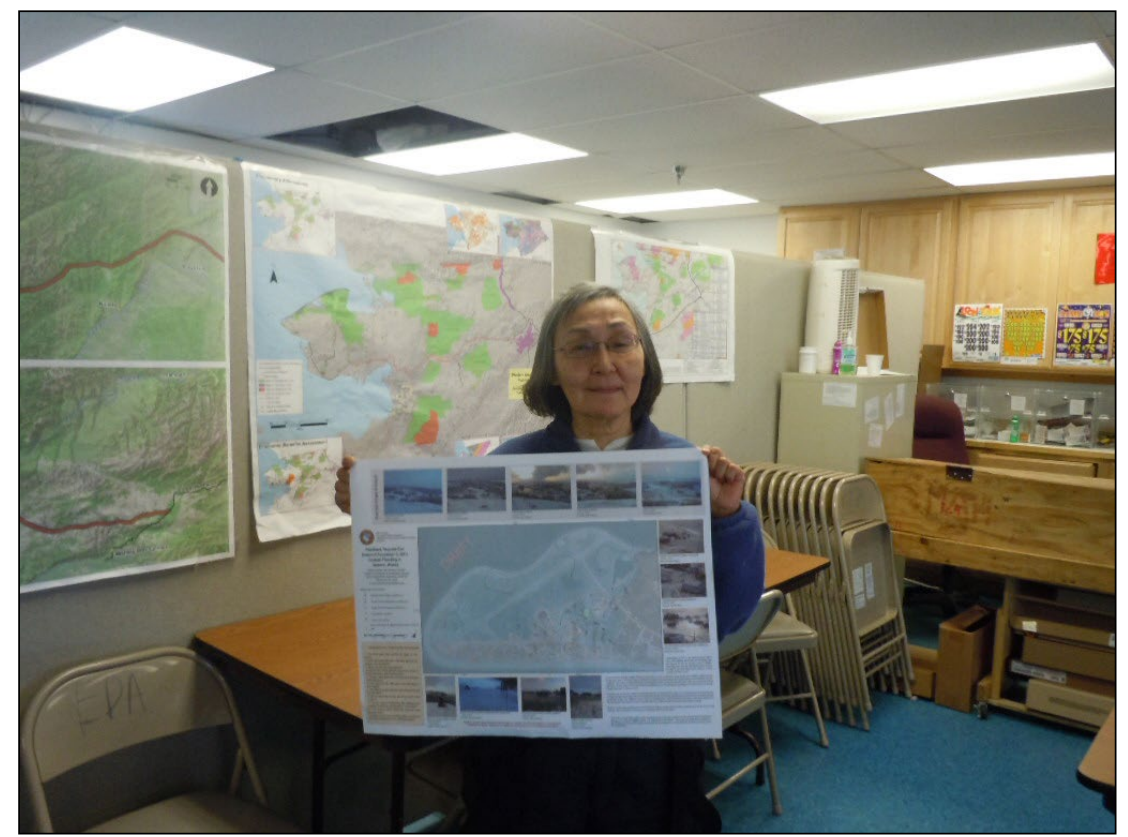


Table 5. Elevations and descriptions of marine flood indicators measured in Golovin, Alaska, on November 15, 2011. Measurements used to infer different types of water levels during the peak storm surge are highlighted: Storm tide (surge + tide; blue), and TWL (surge + tide + wave setup; green).

\begin{tabular}{|c|c|c|c|c|}
\hline $\begin{array}{c}\text { Point } \\
\text { Number }\end{array}$ & $\begin{array}{l}\text { Measurement } \\
\text { Type }\end{array}$ & $\begin{array}{l}\text { Confidence } \\
\text { Level }\end{array}$ & $\begin{array}{l}\text { Elevation }(m \\
\text { NAVD88) }\end{array}$ & Description \\
\hline GLV 14 & Inundation limit & Lowest & $3.18 \pm 0.58$ & Slush line near the corner of the school (modified) \\
\hline GLV_18 & Inundation limit & Lowest & $3.27 \pm 0.58$ & $\begin{array}{l}\text { Elevation of tension cracking in snow surface near } \\
\text { road }\end{array}$ \\
\hline GLV_15 & Inundation limit & High & $3.58 \pm 0.60$ & $\begin{array}{l}\text { Truncated snow and slush line along raised Antone } \\
\text { Street }\end{array}$ \\
\hline GLV_13 & Inundation limit & High & $3.66 \pm 0.59$ & Slush line visible on dike surrounding tank farm \\
\hline GLV_17 & Inundated area & High & $3.78 \pm 0.59$ & $\begin{array}{l}\text { Location of overflow across the road to low-lying } \\
\text { area }\end{array}$ \\
\hline GLV_04 & Inundation limit & High & $3.93 \pm 0.66$ & $\begin{array}{l}\text { Slush line near sewer drain field (minor snow } \\
\text { cover) }\end{array}$ \\
\hline GLV_02 & Inundation limit & Lowest & $4.02 \pm 0.58$ & Transition in slush surface near the old runway \\
\hline GLV_05 & Inundated area & Medium & $4.07 \pm 0.59$ & Slush-covered area near sewer drain field \\
\hline GLV_09 & Inundation limit & Medium & $4.10 \pm 0.58$ & Slush line along a berm that was raised up in 2008 \\
\hline GLV 26 & Inundated area & High & $4.02 \pm 0.66$ & Area by homes that were surrounded with water \\
\hline GLV_01 & Inundation limit & Medium & $4.12 \pm 0.58$ & Slush line along road near generators; ice present \\
\hline GLV_11 & Inundated area & Medium & $4.11 \pm 0.61$ & $\begin{array}{l}\text { Slush-covered area by water holding tank } \\
\text { (modified) }\end{array}$ \\
\hline GLV_23 & Inundated area & Medium & $4.16 \pm 0.57$ & $\begin{array}{l}\text { Low-lying portion of road that was flooded } \\
\text { (modified) }\end{array}$ \\
\hline GLV_27 & imit & west & $4.19 \pm 0.57$ & Slush line along the road near Dexter Roadh \\
\hline GLV_20 & Inundatic & vest & 57 & Slush \\
\hline GLV_12 & Inundati & Medium & & Slush line between the school and the tank farm \\
\hline GLV_24 & Inundation limit & Lowest & 4.27 & $\begin{array}{l}\text { Elevation of tension cracking in snow surface along } \\
\text { road edge, exact slush extent obscured by road } \\
\text { clearing }\end{array}$ \\
\hline GLV_19 & Inundated area & Medium & $4.32 \pm 0.58$ & $\begin{array}{l}\text { Location of overflow across road into low-lying } \\
\text { area }\end{array}$ \\
\hline GLV_16 & Peak flood level & High & $4.32 \pm 0.60$ & $\begin{array}{l}\text { Water level as preserved on the sides of a soil fill } \\
\text { pile between Antone Street and the small craft } \\
\text { harbor fence }\end{array}$ \\
\hline GLV_28 & Inundation limit & Medium & $4.42 \pm 0.58$ & $\begin{array}{l}\text { Slush line on a mound near road at Dexter } \\
\text { Roadhouse }\end{array}$ \\
\hline GLV_07 & Inun & um & 4.4 & Slush line on side of earth foundation below hangar \\
\hline GLV_08 & Inun & & & ion cracking in sn \\
\hline GLV_21 & Inun & dium & 57 & Slush line along hillside edge of a low-lying area \\
\hline GLV_03 & limit & vest & 58 & Transition in slush surface near the old runway \\
\hline GLV_22 & Inundated area & Lowest & $4.66 \pm 0.60$ & Location of overflow forming a pool across the road \\
\hline GLV_30 & Inundation limit & Lowest & $4.80 \pm 0.58$ & $\begin{array}{l}\text { Extent of floodwater on road in front of school, as } \\
\text { determined by an in situ consensus of residents }\end{array}$ \\
\hline GLV_10 & Inundation limit & High & $4.83 \pm 0.58$ & $\begin{array}{l}\text { Slush line between the washeteria and the power } \\
\text { plant }\end{array}$ \\
\hline GLV_31 & Inundation limit & Lowest & $=0.58$ & $\begin{array}{l}\text { Extent of floodwater on road in front of school, as } \\
\text { determined by an in situ consensus of residents }\end{array}$ \\
\hline GLV_29 & Inundated area & Lowest & $5.30 \pm 0.58$ & Slush-covered area on road by church (modified) \\
\hline GLV_06 & Overtopped area & High & 0.60 & $\begin{array}{l}\text { Crest elevation of ice ridge overtopped by waves } \\
\text { (frozen puddle behind) at south tip of community }\end{array}$ \\
\hline GL & Peak flood & $\mathrm{h}$ & $5.59 \pm 0$ & $\begin{array}{l}\text { Water level as observed in a truncated snowdrift on } \\
\text { the cliffs on the north side of community }\end{array}$ \\
\hline
\end{tabular}


The Kitchavik fish camp is $7.5 \mathrm{~km}$ northwest of Golovin on Native Corporation land. Approximately eight cabins and numerous fish drying racks on Native allotments are used in the summers as a base of operations for subsistence activities along Kitchavik River. The cabins that were standing at this site had been built atop stilts to prevent damage from occasional flooding in the area. Many of the cabins had been in place for many years; one structure owned by an elder resident dates to the 1950s. Photographs from a visit to the site of the ivu are shown in figure 24. Ice was piled up at the site to a height of $5 \mathrm{~m}$ and the ice pile wrapped around the entire fish camp and berry-picking site. All of the cabins at this site were extensively damaged by the November 2011 storm, and most had been moved from their original foundations by up to $40 \mathrm{~m}$. One cabin was rafted by floodwaters approximately $0.5 \mathrm{~km}$ to the northeast from its starting location (figs. 24c and 25). As the ice melted in the spring, large volumes of ice-rafted sediment were deposited at the ivu site, making the affected area very apparent from both the ground and the air (fig. 25).

\section{DISCUSSION AND CONCLUSIONS}

Our reconnaissance measurements in four coastal areas following the November 9, 2011, storm (table 6) present a picture of how the peak storm water levels and inundation extents varied in Norton Sound. In general, the amplitude of the total sea surface was greatest at the eastern edge of the Sound, with Shaktoolik experiencing the largest overall increase in water level during the peak surge. Due to the limited tidal instrumentation in Norton Sound, the absolute contribution of the astronomical tide to water levels is unknown outside of Nome. Where observed, nearshore setup values on open ocean segments of the coast contributed to an additional $0.9-1.6 \mathrm{~m}$ rise in the ocean surface. These setup values are consistent with a theoretical maximum setup value of $1.5 \mathrm{~m}$ based on the open ocean wave conditions and existing empirical relationships (Appendix C; Holman and Sallenger, 1985). At isolated locations, wave runup was capable of carrying slush, water, and debris approximately 2-4 m higher than the peak elevation of the storm surge. As would be expected, maximum runup elevations were

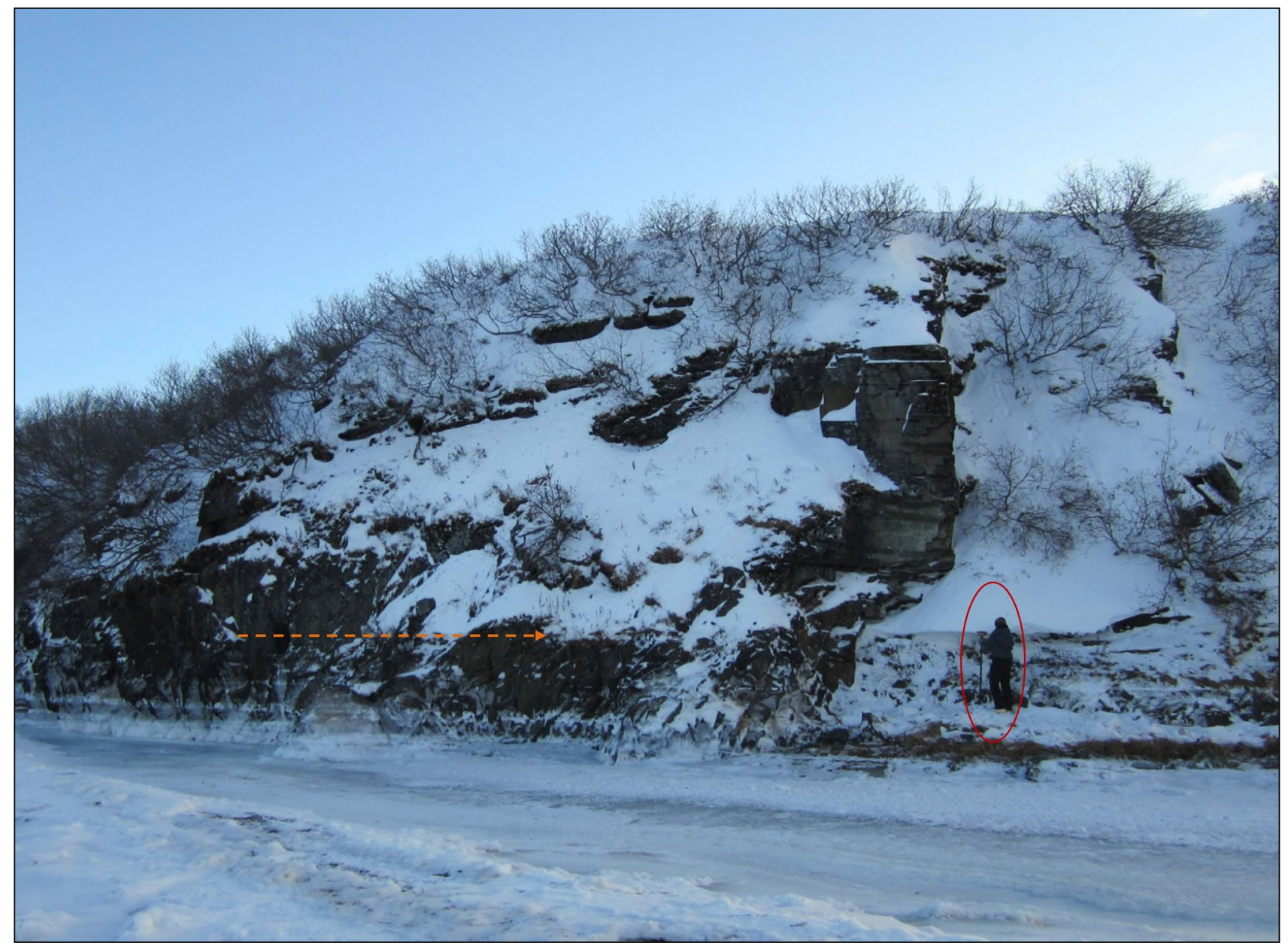

Figure 23. Total floodwater level as preserved in a truncated snowdrift on the sedimentary cliffs to the north of town, along the Golovnin Lagoon shoreline. The peak water line is highlighted by the orange arrow; the elevation of the line was measured at the location shown with the person in the red ellipse (GLV_32, table 5). 
observed in coastal areas exposed to heightened wave energy, for example, areas subject to refractive wave focusing (convex coastal bluff edges in Nome) and areas with deeper nearshore depths (old community site in Shaktoolik).

We used inundation limits on sheltered portions of coastline (in lagoons, rivers, etc.) to approximate the storm tide levels presented in table 6; however, these areas are not fully sheltered from the effects of wind and wave setup or runup so they represent an upper limit approximation. In Nome, our measured storm tide elevation (3.3 $\mathrm{m}$ above MSL; table 6 ) is approximately $50 \mathrm{~cm}$ greater than the peak water elevation documented by the NOAA tide gauge at the mouth of Snake River (2.8 m MSL at 16:54 AKST). A discrepancy of this magnitude between surge heights measured in the field and tide gauge records is typical because of the differences in the methods of measurements (National Weather Service, 2010; oral commun., Sallenger, 2012), and we can infer that the true storm tide elevation may be slightly lower than the elevation that is measured using field techniques. Additional factors may also contribute to this discrepancy: for example, floating ice and debris on top of the water surface is capable of pushing slush farther onshore. In Shaktoolik, 'whale-sized' pieces of ice were reportedly transported in the swiftly moving current of Tagoomenik River during the storm, and the accumulation of ice and slush at the inlet may have dammed the ebb of the surge and increased sheltered water level measurements above pure storm tide levels. This would be consistent with observations of ice and slush at the river mouth as well as reportedly higher water along Tagoomenik River than in previous storms of similar magnitude. Conversely, in places such as Unalakleet, the observed storm tide elevation may be much closer to the true storm tide level because the coastal geometry presented more opportunities to measure inundation limits in sheltered locations.

Due to the limited number of well-documented storms in this part of Alaska, the recurrence interval for a storm of this magnitude is somewhat subjective. In 1981, Wise and others produced a statewide set of empirical storm surge frequency curves based on the relationship between historic surge elevations with associated atmospheric conditions and regional frequencies of various wind speeds. According to this early study, the November 9, 2011, surge in Nome corresponded to a 40-year event. The surge in Unalakleet would be considered a 20-year event, and in Shaktoolik the observed

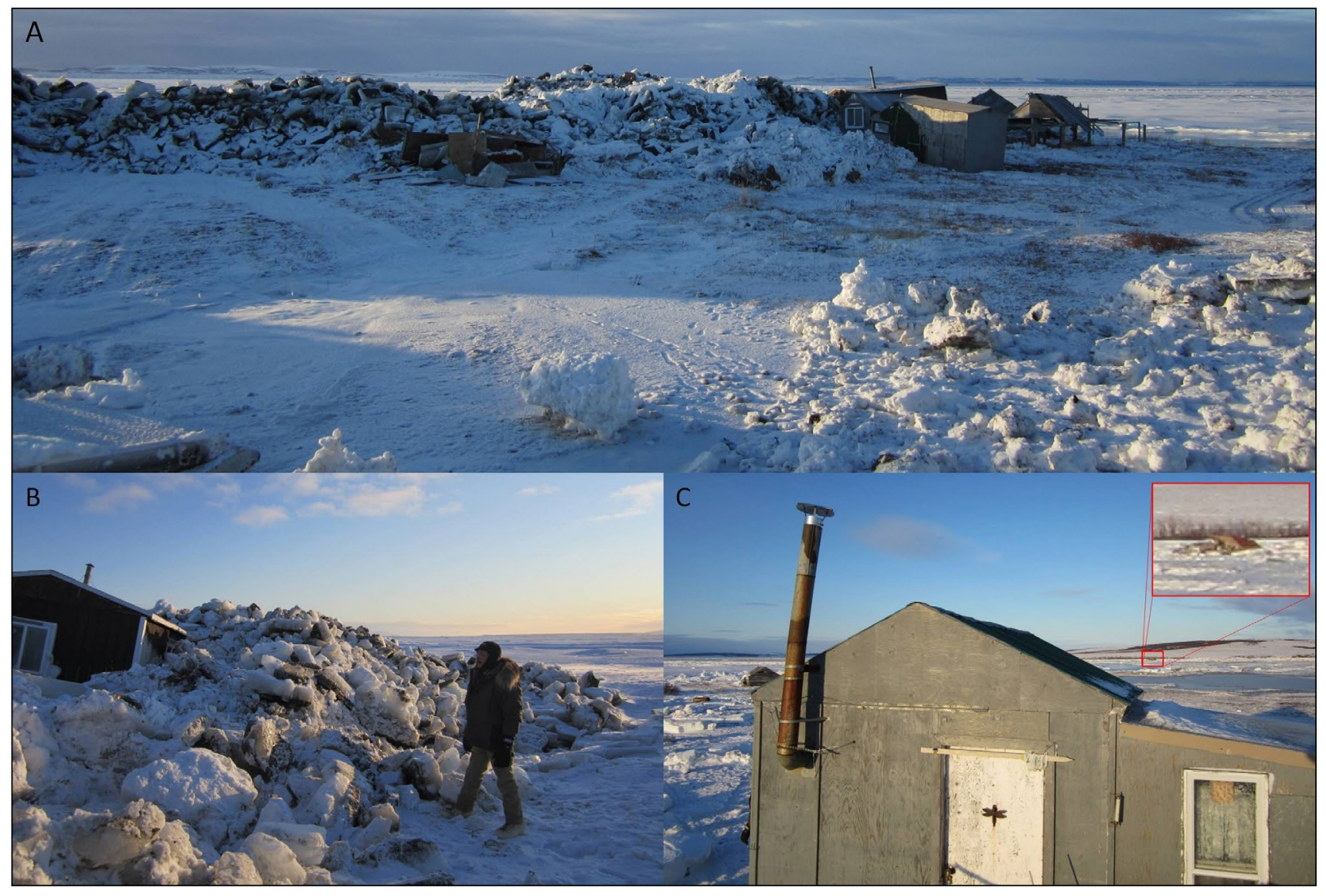

Figure 24. Photos documenting the ivu that occurred at the mouth of Kachauik River: (a) Looking southwest across the fish camp at the forward edge of the ivu that damaged all of the cabins on the site; (b) Toby Anungazuk, a cabin owner, stands beside a building that was transported by the ivu; and (c) a photo taken from the fish camp shows a cabin in the distance (red inset) that floodwater rafted approximately $0.5 \mathrm{~km}$ to the northeast. 


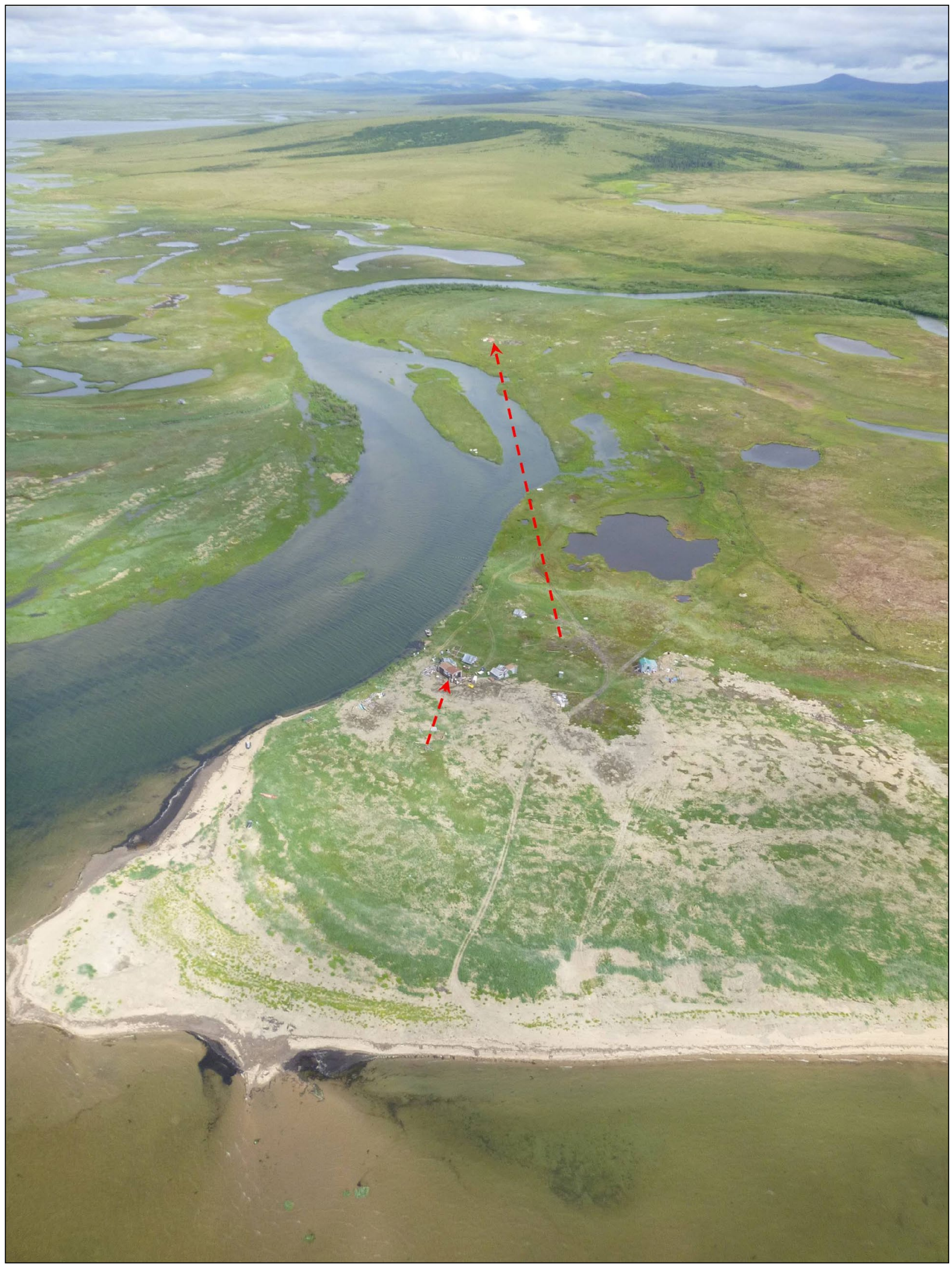

Figure 25. Oblique aerial image of the fish camp at the mouth of Kachauik River taken July 2012, eight months after the storm. The approximate transport distances of two cabins from their pre-storm foundation locations are depicted by red arrows and the deposition of ice-rafted sediment up to $150 \mathrm{~m}$ inland is apparent. 
Table 6. A side-by-side comparison of Norton Sound tidal ranges and November 9, 2011, peak storm water levels as interpreted from various types of flood indicators that the DGGS team measured in the field. Colors correspond to those in tables 2 thru 5; '-'signifies that the water level type was not measured.

\begin{tabular}{|c|c|c|c|c|c|}
\hline Water Level Type & Vertical Datum & Unalakleet & Shaktoolik & Nome & Golovin \\
\hline \multirow{2}{*}{$\begin{array}{l}\text { Storm Tide Level } \\
(\text { surge }+ \text { tide })\end{array}$} & Local MSL & $2.7 \mathrm{~m}$ & $3.3 \mathrm{~m}$ & $3.3 \mathrm{~m}$ & no tidal datum \\
\hline & $\begin{array}{l}\text { NAVD88 } \\
\text { (GEOID09) }\end{array}$ & $4.1 \mathrm{~m}$ & $4.7 \mathrm{~m}$ & $4.4 \mathrm{~m}$ & $4.3 \pm 0.6 \mathrm{~m}$ \\
\hline \multirow{2}{*}{$\begin{array}{l}\text { TWL, Total Water Level } \\
\text { (surge + tide + setup) }\end{array}$} & Local MSL & $4.2 \mathrm{~m}$ & - & $4.2 \mathrm{~m}$ & no tidal datum \\
\hline & $\begin{array}{l}\text { NAVD88 } \\
\text { (GEOID09) }\end{array}$ & $5.7 \mathrm{~m}$ & - & $5.3 \mathrm{~m}$ & $5.6 \pm 0.6 \mathrm{~m}$ \\
\hline \multicolumn{6}{|l|}{ Water Level Component } \\
\hline Mean Tidal Range & & $0.97 \mathrm{~m}$ & $0.74 \mathrm{~m}$ & $0.31 \mathrm{~m}$ & $<0.55 \mathrm{~m}$ \\
\hline $\begin{array}{l}\text { Storm Surge Height } \\
\text { (Storm tide level - predicted tide) }\end{array}$ & & - & - & $3.2 \mathrm{~m}$ & - \\
\hline $\begin{array}{l}\text { Wave Setup Height } \\
\text { (Storm tide level - TWL) }\end{array}$ & & $+1.6 \mathrm{~m}$ & - & $+0.9 \mathrm{~m}$ & $+1.3 \mathrm{~m}$ \\
\hline $\begin{array}{l}\text { Maximum Runup in Community } \\
\text { (height above storm tide level) }\end{array}$ & & $+3.1 \mathrm{~m}$ & $+2.3 \mathrm{~m}$ & - & - \\
\hline $\begin{array}{l}\text { Maximum Runup } \\
\text { (height above storm tide level) }\end{array}$ & & $+3.5 \mathrm{~m}$ & $+4.4 \mathrm{~m}$ & $+3.1 \mathrm{~m}$ & - \\
\hline
\end{tabular}

surge height corresponded to a nearly 100 -year event on the calculated curve for eastern Norton Sound. The report by Wise and others (1981) suggests that the surge magnitudes in northern Norton Sound are greater in size compared to those in eastern Norton Sound. Our measurements suggest more similar surge heights during the 2011 storm. Following the 1974 event, Sallenger (1983) reported coastal water elevations to be greatest along the eastern edge of Norton Sound, ranging from 3 to $4.75 \mathrm{~m} \mathrm{MSL} \mathrm{(including} \mathrm{runup).} \mathrm{The}$ regional variability of surge heights within eastern Norton Sound and the relative height inconsistencies that are based on in situ observations suggest that the report by Wise and others (1981) presents an over-simplification of recurrence intervals for eastern Norton Sound and should no longer be used as a reliable estimate of surge elevations for this region (Sector 9; Wise and others, 1981).

A 2009 study conducted by Chapman and others at the U.S. Army Corps of Engineers Coastal and Hydraulics Laboratory used storm hindcasting, a hydrodynamic circulation model, and a detailed bathymetric grid of Norton Sound to develop frequency-of-occurrence relationships for storm-surge water levels. The results of this modeling study indicate that the November 9, 2011, surge corresponds to a 10- to 15-year event for Unalakleet, a 15- to 25-year event for Shaktoolik, and a 100-year event for Nome (or a 50-year event based on the tide gauge values). The current Flood Insurance Study for the City of Nome (FEMA, 2010) presents flood elevation recurrence intervals that reflect the combined effects of astronomical tide, storm surge, wave setup, and runup; the November 9, 2011, water level was a 50-year event by this calculation.

The National Weather Service's Meteorological Development Laboratory generates storm surge predictions as part of their Extratropical Water Level Forecast program. These surge predictions are generated every 6 hours and are driven by the Global Forecast System (GFS) atmospheric model. A comparison of the measured surge heights (measured water level minus predicted astronomical tide) in Nome to the forecasted surge heights modeled by NWS during the storm is presented in figure 26. The magnitudes of the modeled storm surge heights encompass the peak observed storm tide levels in the four communities that we visited. As was demonstrated in the October 18-20, 2004, storm (Hufford and Partain, 2004), the NWS model was able to accurately predict the track, intensity, and timing of this storm with enough precision to produce site-specific surge predictions that could be used for emergency planning purposes.

Remeasured coastal profiles exhibited morphology typical of seasonal change, such as the removal of midbeach berms. Coastal retreat was only observed at a few locations; however, we observed notching at the base of bluffs, bluff or upper scarp steepening and the removal of vegetation, talus toes or protective debris at many of the revisited profiles. We anticipate the types of profile modifications we observed in the field at some locations will result in up to $1 \mathrm{~m}$ of coastal retreat of the bluff edge when thawing and re-equilibration occurs over the next year. Many of our post-storm coastal profiles also included one or more ice ridges or berms, some in excess of $1 \mathrm{~m}$ tall, on the lower shoreface. While these accreted ice features obscured the beach surface, they preserve a record of secondary surge elevations because they are deposited just above a peak water level. In Unalakleet a very consistent ice berm with a crest elevation of $3 \mathrm{~m}$ MLLW was observed in nearly all of the profiles. Unlike observations following the 1974 storm (Sallenger and Dingler, 1978; oral commun., Sallenger, 2012), the shoreface was not swept 
clear of log-sized driftwood in most locations as a result of this storm and no new debris berms were observed at any of the revisited sites.

The ways in which this particular storm affected each community was shaped by both natural and man-made factors. The timing and direction of winds led to the development of protective bands of nearshore slush, particularly in front of Shaktoolik, which reduced the open-ocean wave energy in most of the communities we visited. The lag between the peak winds and peak surge also lessened the effects of the storm because maximum wind waves did not coincide with the peak surge. Engineering structures in the coastal zone, such as the revetment at the mouth of Unalakleet River and the newly elevated Antone Street on the lagoon side of Golovin, protected areas where floodwaters have spilled into communities in the past. Additionally, the advance warning from the National Weather Service and implementation of local emergency plans (Hufford and Partain, 2004) were instrumental in reducing damages including the loss of life and property.

As recognized by others, a timely field-response is critical to quantitatively document the extent of storm-related coastal flooding before features are obscured and cleanup occurs (NWS, 2010). Most documented rapid field responses to coastal flooding have been conducted following hurricanes or other warm-weather storms. The remote nature and harsh weather of northwestern Alaska present some unique difficulties to mounting a rapid response. Obstacles that the DGGS crew encountered included high winds, limited availability of daylight for field activities, difficulty accessing frozen or buried benchmarks, electronic issues in the equipment caused by condensation in fluctuating temperatures, and drifting snow that quickly covered evidence of the recent flood in some areas (fig. 27).

While harsh weather inhibited some components of field operations, the cold also allowed for unique flood indicators that would not have been present in warmer climates. For example, tension cracks on the surface of the snow along the limit of inundation and truncated snowdrifts preserved the location of flood limits in areas where they would not have otherwise been visible. Furthermore, the deposition of slushfilled seawater at peak surge changed the character of the snow and ice at the surface so that in areas where snow had obscured the storm inundation extent we could traverse across the surface of the snow and could feel the extent of flooding in the behavior of the ice below our feet. In many cases, low-lying areas that were inundated during the peak surge were not able to drain due to frozen ground, and the water was frozen in place. Also, the abundance of large driftwood (and ice) in Norton Sound produced numerous debris lines that could be used to measure the extent of flood inundation.

By traveling to affected areas immediately after the storm we were able to collect photos, video, and eyewitness accounts that improved our final interpretations. In the summer, when most of our coastal hazards mapping field activities occur, local residents are often are too busy with subsistence activities to locate old photos of storm events. We found that the active involvement of community members was a critical component of completing this rapid response work, particularly in the smaller communities. The prevalence of subsistence activities in some Alaskan villages poses additional challenges to coastal hazard evaluation and response

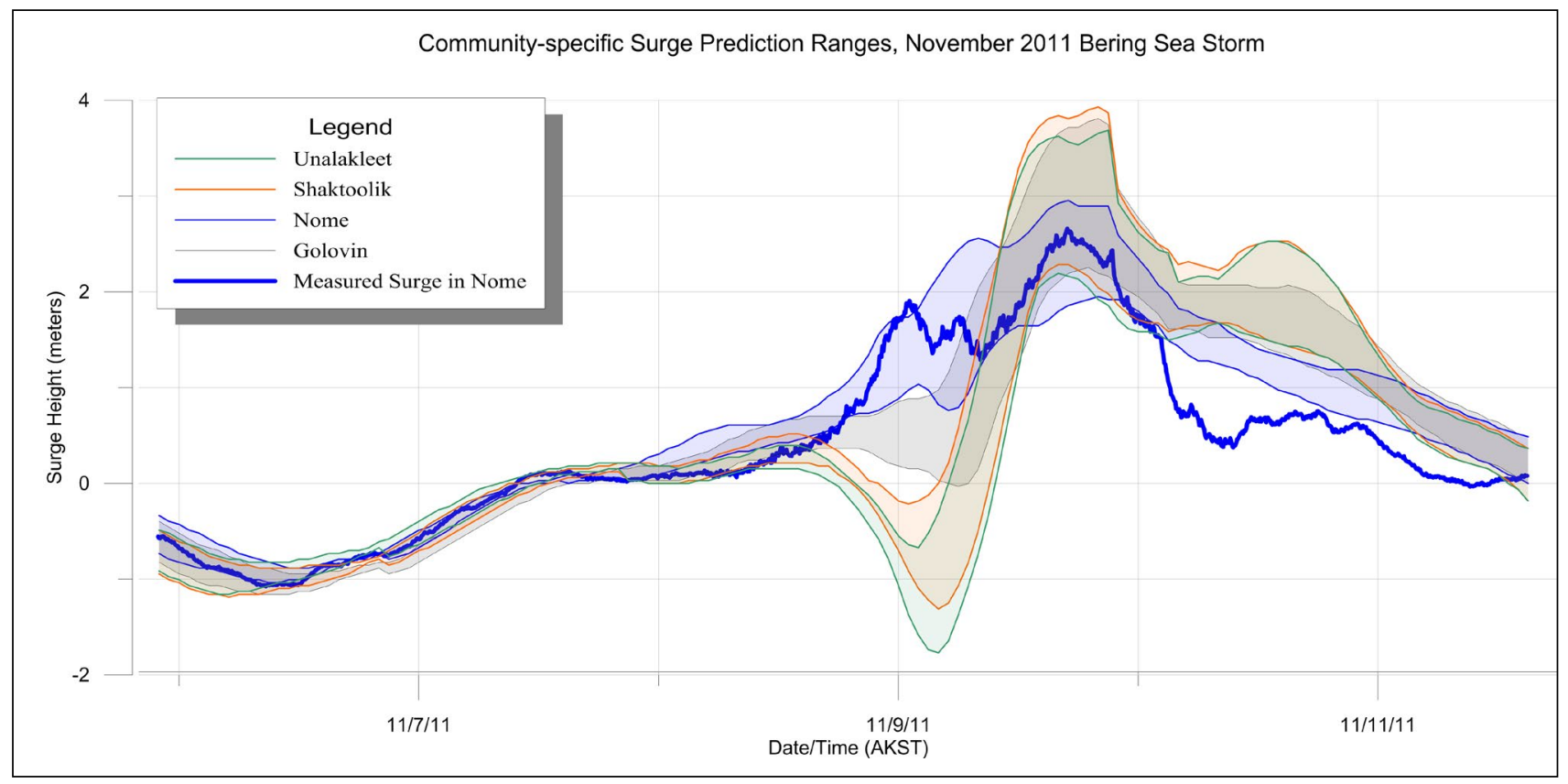

Figure 26. Plots of the total range of peak storm surge predictions made for each visited community as a function of time based on output from 20 individual National Weather Service model runs that were executed every six hours from November 6 to November 11, 2011. 
because it changes the value emphasis on some community resources that are not present in much of the United States. For example, "fish camps provide an important winter food source, especially to low-income families" and damages to these types of temporary dwelling structures are not eligible for repair or replacement under federally declared disasters (written commun., Anungazuk, 2012).

Based on our team's experiences in the field we would make the following recommendations to improve future rapid response work or to assist researchers working in similar conditions:

- If possible, install temporary water-level gauges in advance of storm events

- Attempt to identify benchmarks with published vertical positions that can be easily accessed in winter conditions for improved vertical control on measurements

- Maintain regular communication with emergency coordinators to ensure that field activities do not interfere with necessary emergency procedures

- Encourage residents to set timestamps on their personal cameras prior to a large storm event or note exact times of photograph collection

- Encourage residents to place stakes or other visible markers along water lines in the event that flood indicators have been lost by the time a field crew arrives

- In cold weather climates, revisiting coastal profiles both immediately after an event and post-thaw is necessary to fully document event-related change

- A continued expansion of the tide-gauge network in northwestern Alaska would improve local tidal datum corrections and improve site-specific predictions

During the summer of 2012, our team will continue CIAPfunded coastal hazard investigations in Golovin, along the Nome-Council Road and in other parts of western Alaska. This work will involve new baseline coastal profiles and remeasurement of the three profiles that were established in Nome during the course of this reconnaissance trip. Additional work in Golovin in 2012 will examine rates of erosion along the bay side of the community and also investigate in more detail the site of the ivu. We will use the post-storm observations to improve our interpretation of coastal landforms and the evolution of coastal morphology in this region to enhance coastal hazard assessments. If conditions permit, the DGGS Coastal Hazards Program will conduct additional post-storm field activities of this type in the future.

\section{ACKNOWLEDGMENTS}

DGGS rapid response fieldwork following the November 2011 Bering Sea storm was funded with qualified outer continental shelf oil and gas revenues by the Coastal Impact Assistance Program, U.S. Fish \& Wildlife Service, U.S. Department of the Interior. The views and conclusions contained in this document are those of the authors and should not be interpreted as representing the opinions or policies of the U.S. government. Mention of trade names or commercial products does not constitute their endorsement by the U.S. government.

Bryan Fisher and the entire staff of the November 2011 Incident Command Center in Anchorage provided our DGGS team with timely information regarding on-the-ground conditions throughout the affected area, allowing us to time our arrival as soon after the storm as possible without interfering in emergency activities. Archived Global Forecast System surge predictions and National Weather Service statements from November 2011 were obtained with the assistance of John Lingaas at NOAA. We would like to thank Walter Combs and John Truitt at the FAA Aviation Cameras Program for retrieving FAA webcam captures before deletion. George Plumley (DCCED) and Alexa Green (DOT\&PF) provided us with critical elevation data that allowed us to constrain the vertical control in Golovin. Julie Prusky and Dave Doyle at NOAA/NGS gave guidance for adjustment to

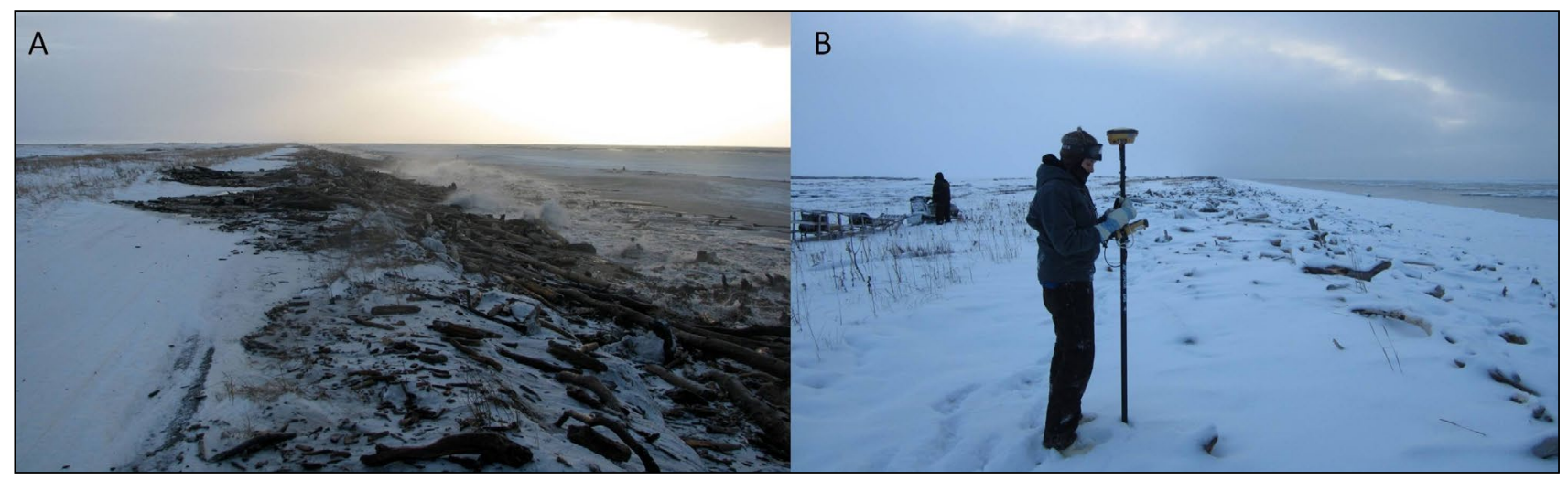

Figure 27. These two photos taken near the runway at the old community site south of Shaktoolik illustrate the importance of a rapid response to collect useful measurements of storm surge elevations. The slush and debris lines clearly visible (a) within a day of the storm (photo by Elmer Bekoalok) were already being obscured by snow (b) less than four days after the event. 
the tidal datum in Nome. We would also like to thank Abby Sallenger for taking the time to discuss his post-1974 storm observations from the region with us. Ann Gibbs (USGS), Bruce Richmond (USGS), Ruth Carter (DOT\&PF) and Toby Anungazuk (Chinik Eskimo Community, Golovin) provided insightful reviews and recommendations that have greatly improved the final manuscript.

We would like to extend our deepest gratitude to all of the community residents who took the time to share their videos, photographs, and observations with us and to those who provided us with feedback that improved this report. We would not have been able to collect many of the measurements contained in this report without the logistical support, transportation, and lodging to which we were generously given access so soon after the storm occurred. In particular we would like to thank the following people for their exceptional assistance in support of this work: Steve Ivanoff, Harry Johnson, and Maggie Halleran of Unalakleet; Eugene Asicksik, Myron Saveitilik, Elmer Bekoalok, Harvey Sookiayak, and the Paniptchuk family of Shaktoolik; as well as Chon Peterson, Don and Carol Oliver, and Jack Fagerstrom of Golovin.

\section{REFERENCES}

Alaska Department of Commerce, Community \& Economic Development (DCCED), and Kawerak, Inc., 2004, Area use and detailed community maps, Golovin, Alaska: Alaska Department of Commerce, Community and Economic Development, Anchorage, Alaska, 4 sheets, http://www. commerce.state.ak.us/dca/profiles/profile-maps.htm

Alaska Department of Military and Veterans Affairs (DMVA), October 2010, State of Alaska hazard mitigation plan: Alaska Division of Homeland Security and Emergency Management, 888 p., http://ready.alaska.gov/plans/ documents/SHMP_2010_UPDATE_ENTIRE_FINAL_ COMPLETE.pdf

Blier, Warren, Keefe, Stanley, Shaffer, Wilson A., and Kim, Sung C., December 1997, Storm surges in the region of western Alaska: Monthly Weather Review, vol. 125, p. 3,094-3,108.

Chapman, Raymond S., Kim, Sung-Chan, and Mark, David J. for U.S. Army Corps of Engineers, Alaska District, 2009, Storm damage and flooding evaluation, storminduced water level prediction study for the western coast of Alaska: Vicksburg, Mississippi, U.S. Army Engineer Research and Development Center, Coastal and Hydraulics Laboratory, $92 \mathrm{p}$.

City of Golovin, Hazard Mitigation Planning Team and URS, Agnes Moses, ed., November 2008, The City of Golovin multi-hazard mitigation plan: The City of Golovin, $96 \mathrm{p}$.

City of Nome, Nome Planning Commission, and Bechtol Planning \& Development, February 2008, The city of Nome, Alaska 2008 local hazards mitigation plan update: City of Nome, Alaska, 94 p., http://www.commerce. state.ak.us/dca/planning/nfip/Hazard_Mitigation_ Plans/Nome_HMP.pdf
City of Unalakleet, WHPacific, Incorporated of Alaska, and Bechtol Planning and Development, June 2008, City of Unalakleet, Alaska local hazards mitigation plan: City of Unalakleet, Alaska, 70 p., http://www.commerce.state. ak.us/dca/planning/nfip/Hazard_Mitigation_Plans/ Unalakleet_LHMP.pdf

Doran, Kara S., Stockdon, Hilary F., Plant, Nathaniel G., Sallenger, Asbury H., Jr., Guy, Kristy K. and Serafin, Katherine A., 2009, Hurricane Gustav-Observations and analysis of coastal change: U.S. Geological Survey, Open-File Report 2009-1279, 28 p., http://pubs.usgs. gov/of/2009/1279/

Douglas, D.C., 2010, Arctic sea ice decline-Projected changes in timing and extent of sea ice in the Bering and Chukchi seas: U.S. Geological Survey Open-File Report 2010-1176, 32 p., http://pubs.usgs.gov/of/2010/1176/

Fathauer, T.F., 1975, The great Bering Sea storms of 9-12 November 1974: Weatherwise, v. 28, p. 76-83.

Federal Emergency Management Agency (FEMA), May 2010, Flood insurance study, city of Nome, Alaska: FEMA Flood Insurance Study Number 020069V00A, 16 p., http://www.nomealaska.org/egov/ docs/1304373016_535858.pdf

Forbes, Donald L., ed., 2011, State of the arctic coast 2010Scientific review and outlook: Geesthacht, Germany, International Arctic Science Committee, Land-Ocean Interactions in the Coastal Zone, Arctic Monitoring and Assessment Programme, International Permafrost Association, Helmholtz-Zentrum, 178 p., available online at http://arcticcoasts.org

Glenn Gray \& Associates, Kawerak, Inc., and the Community of Shaktoolik, 2012, Shaktoolik planning project, situation assessment: Juneau, Alaska, Glenn Gray \& Associates, $63 \mathrm{p}$.

Holman, R.A., and Sallenger, A.H., Jr., 1985, Setup and swash on a natural beach: Journal of Geophysical Research, v. 90 n. C1, p. 945-953, http://ir.library. oregonstate.edu/xmlui/bitstream/handle/1957/16350/ Holman_and_Sallenger_JGR_1985.pdf

Hufford, Gary, and Partain, James, 2004, Climate change and short-term forecasting for Alaskan northern coasts: Anchorage, Alaska, National Weather Service, 5 p., https:// ams.confex.com/ams/pdfpapers/83001.pdf

Johnson, Walter R., and Kowalik, Zygmunt, 1986, Modeling of storm surges in the Bering Sea and Norton Sound: Journal of Geophysical Research, v. 91, no. C4, p. 5,119-5,128.

Native Village and City of Shaktoolik, WHPacific, and Bechtol Planning and Development, October 2009, Community of Shaktoolik, Alaska local multi-hazard mitigation plan: City of Shaktoolik, Alaska, 93 p.

National Oceanic and Atmospheric Administration (NOAA), 2012, Tides \& Currents, Center for Operational Oceanographic Products and Services, website last accessed September 2012: http://tidesandcurrents.noaa.gov/ 
National Weather Service (NWS), 2010, Introduction to Storm Surge: National Hurricane Center, Storm Surge Unit, 5 p., http://www.nhc.noaa.gov/surge/

2011, Public information statement 7:15 AM AKST, 11-7-2011: Fairbanks, Alaska, National Weather Service, $1 \mathrm{p}$.

Natural Resource Conservation Service (NRCS), April 2003, Flood plain management study for the city and Native village of Unalakleet, Alaska: Natural Resources Conservation Service, U.S. Department of Agriculture, 75 p.

Orth, D.J., 1971, Dictionary of Alaska place names (reprint with minor revisions): U.S. Geological Survey, Geological Survey Professional Paper 567, 1,084 p., http://www. dggs.alaska.gov/webpubs/usgs/p/text/p0567.PDF

Parnell, Sean, December 5, 2011, State of Alaska declaration of disaster emergency: Juneau, Alaska, Office of the Governor of the State of Alaska, $4 \mathrm{p}$.

Perovich, Donald K., and Richter-Menge, Jacqueline A., 2009, Loss of sea ice in the arctic: Annual Review of Marine Science, v. 1, p. 417-441, http://imb.crrel.usace. army.mil/pdfs/annurev.marine.010908.pdf

Sallenger, Asbury H., Jr., 1983, Measurements of debris-line elevations and beach profiles following a major stormNorthern Bering Sea coast of Alaska: U.S. Geological Survey Open-File Report 83-394, 12 p.

Sallenger, Asbury H., Jr., and Dingler, John R., 1978, Coastal processes and morphology of the Bering Sea coast of Alaska - Environmental assessment of the Alaskan continental shelf: Menlo Park, California, U.S. Geological Survey, Final reports of principal investigators, Research Unit No. 431, v. 2, p. 377-441.

Smith, H.N., and Carter, R.A., 2011, Over 25 years of applied coastal engineering in Alaska: Proceedings of the 2011 Conference on Coastal Engineering Practice, American Society of Civil Engineers, $14 \mathrm{p}$.

United States Army Corps of Engineers (USACE), October 2011a, Shaktoolik coastal flooding analysis: Alaska District, 73 p.

October 2011b, Flood hazard data for Alaska communities: Alaska District, Civil Works Floodplain Management, available online. http://www.poa.usace.army. mil/en/cw/fld_haz/floodplain_index.htm

2008, Coastal erosion control, Unalakleet, Alaska: Alaska District, contract no. W911KB-09-C-0011, 265 p.

United State Census Bureau, 2010, Profile of general population and housing characteristics, 2010 demographic profile data, available online. http://factfinder2.census. gov/main.html

United States Department of the Army, Coastal Engineering Research Center (CERC), 1984, Shore protection manual, 4th edition, vol. 1: U.S. Department of the Army, Waterways Experiment Station, Corps of Engineers, Vicksburg, Mississippi, 337 p., http://ia600208. us.archive.org/14/items/shoreprotectionm01unit/ shoreprotectionm01unit.pdf
United States Government Accountability Office (GAO), June 2009, Report to congressional requestors-Alaska Native villages, limited progress has been made on relocating villages threatened by flooding and erosion: U.S. General Accountability Office Report GAO-040895T, 53 p., available online at http://www.gao.gov/products/ GAO-09-551

United States Government Accounting Office (GAO), 2003 [2004], Alaska Native villages-Most are affected by flooding and erosion, but few qualify for federal assistance: U.S. General Accounting Office Report GAO04-142, 82 p., available online at http://www.gao.gov/ products/GAO-04-142

Wise, James L., Comiskey, Albert L., and Becker, Richard, 1981, Storm surge climatology and forecasting in Alaska: Anchorage, Alaska, Arctic Environmental Information and Data Center, University of Alaska, 32 p. 


\section{Appendix A}

Atmospheric Conditions, Unalakleet Airport Automated Weather Station, Nov. 5-12, 2011

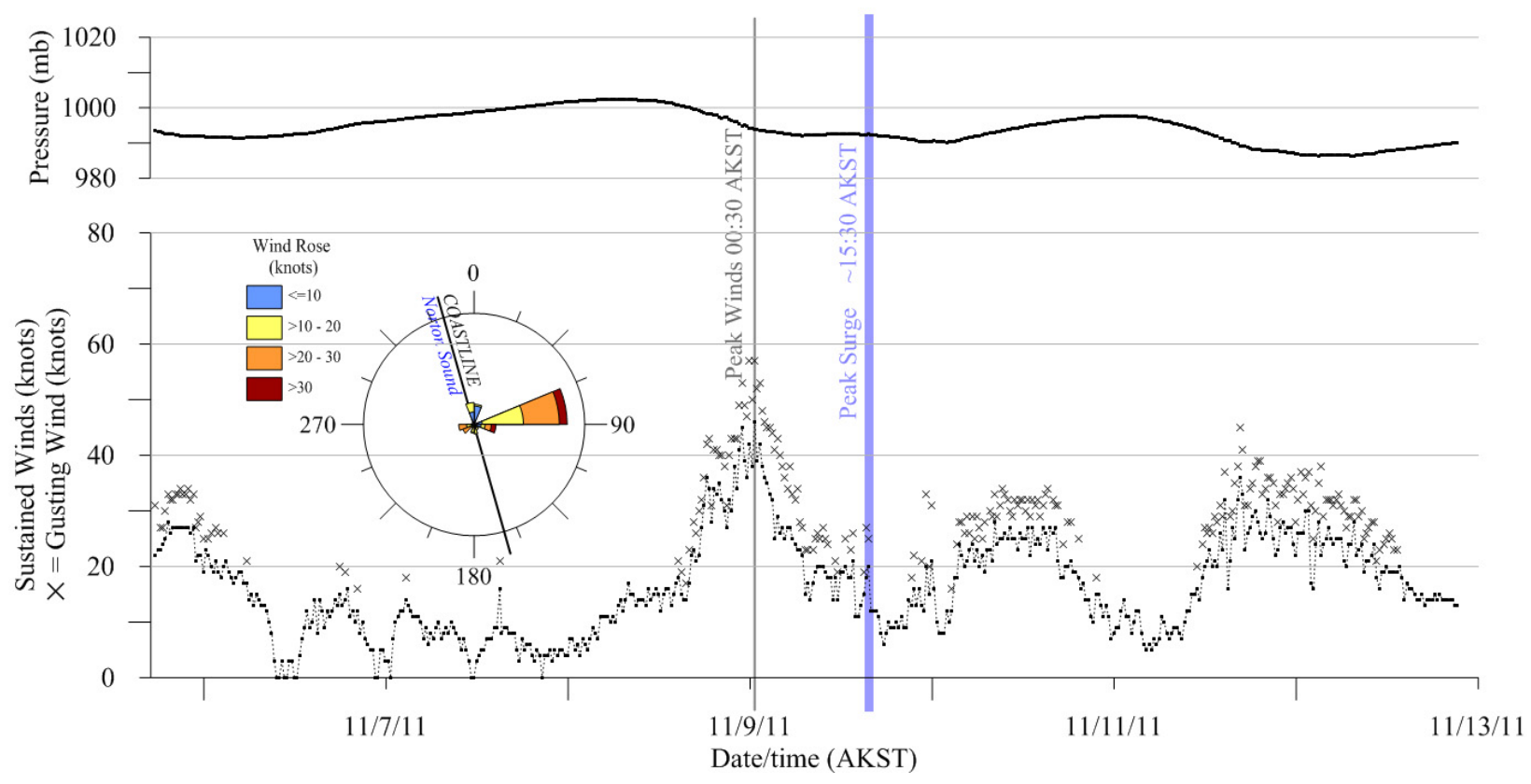

Note: Estimated time of peak surge in Unalakleet is based on FAA webcam images.

Atmospheric Conditions, Golovin Airport Automated Weather Station, Nov. 5-12, 2011 Note: Gaps in data due to weather station outages

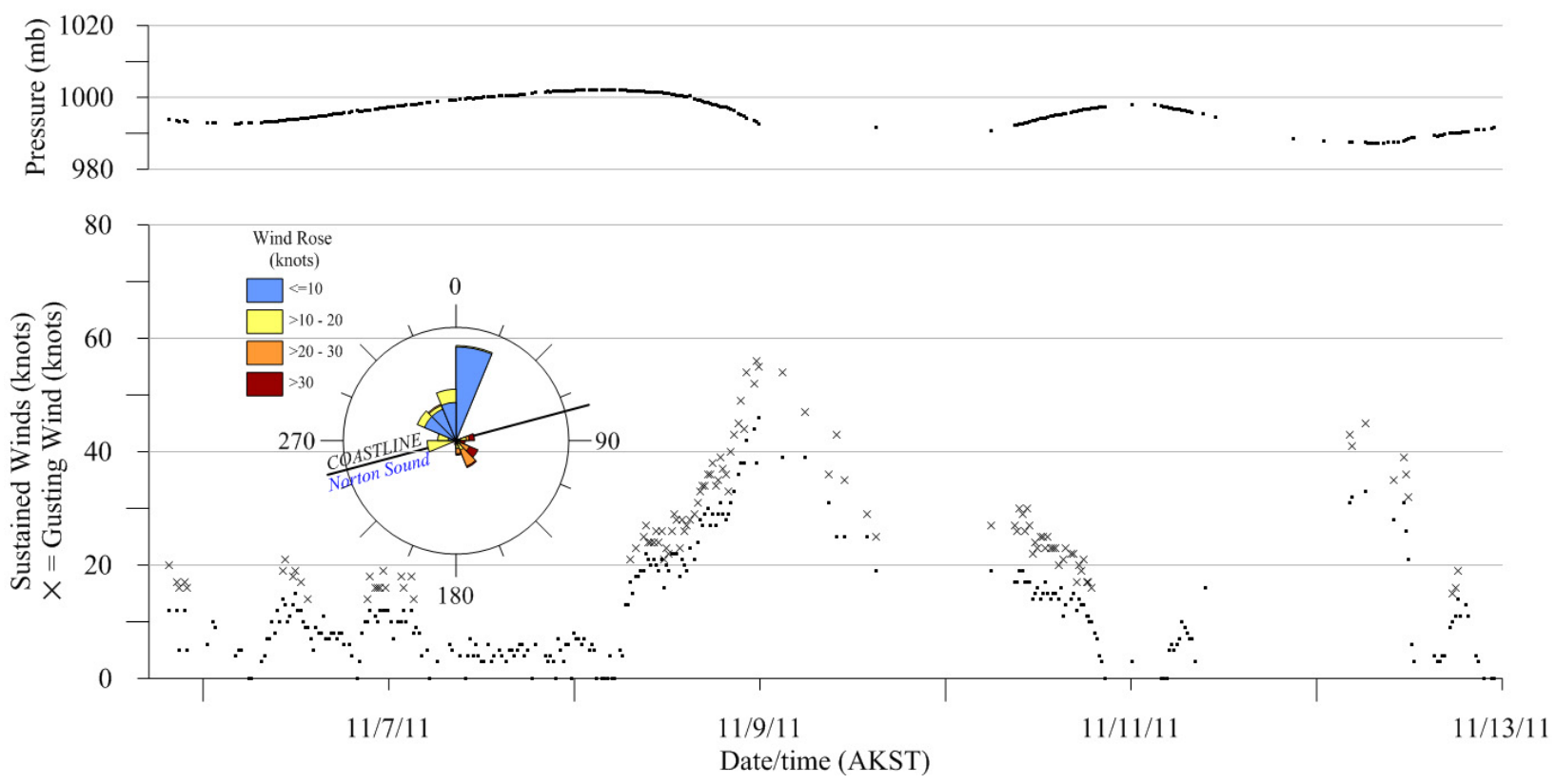





\section{Appendix B}

Fifteen coastal profiles that were established by DGGS in July 2011 were revisited following the November 2011 Bering Sea Storm. The following pages include detailed information regarding each of the resurveyed profiles listed in the table below. For each location we present a vertical plot of July and November 2011 profiles, a short summary of key features observed, and representative photographs. The average precision values presented for each profile are the standard deviation of the post-processed data and are not representative of total GPS error (coordinate precision + positional accuracy). GPS accuracy was best during the summer surveys; accuracies were better than 4 $\mathrm{cm}$ in both the horizontal and vertical directions for all of the presented data. More detailed profile information may be available in location-specific DGGS reports.

\begin{tabular}{ll} 
Community & Remeasured Profile Number \\
\hline Unalakleet & Profile 05 \\
& Profile 06 \\
& Profile 07 \\
& Profile 10 \\
& Profile 11 \\
& Profile 12 \\
& Profile 13 \\
& Profile 14 \\
& Profile 15 \\
& Profile 16 \\
& Profile 14 \\
& Profile 20/21 \\
& Profile 29 \\
& Profile 30
\end{tabular}



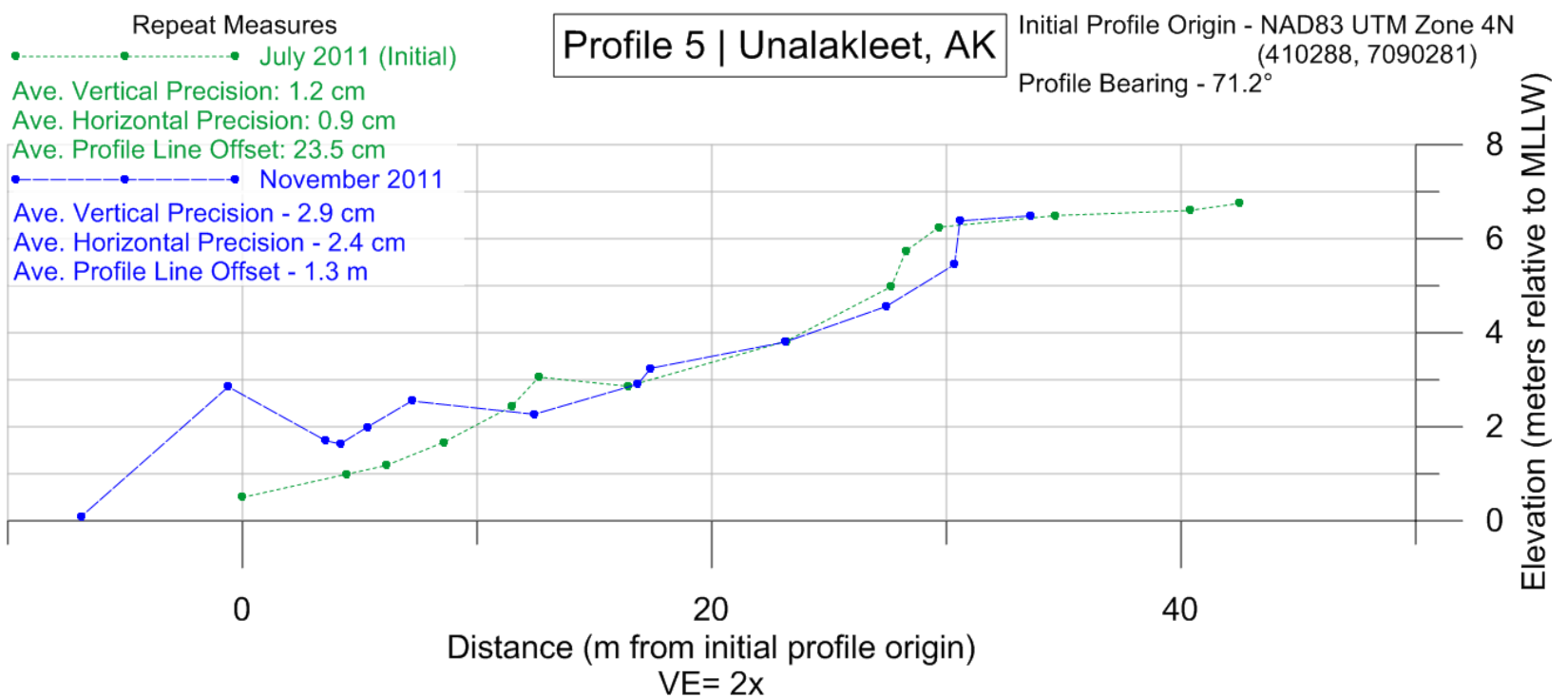

\section{Profile Setting:}

Located $5.4 \mathrm{~km}$ north of the Unalakleet airport. Profile extends from Norton Sound to the road (across the road in July profile) that leads north to Powers Creek. The backbeach is characterized by a low coastal bluff capped by grassy vegetation.

\section{July 2011 Notes:}

- Coarse sand lens present in the intertidal zone

- Moderately-well-developed gravel horns/beach cusps on lower shoreface

- Well-developed berm on the mid shoreface

- Woody debris concentrated in mid shoreface runnel and at the toe of low backbeach bluff

- Scarped portion of bluff composed of interbedded sands and gravels with organic cap

- Talus toe present at base of coastal bluffs

- Woody debris observed atop shoulder of bluffs

\section{November 2011 Notes:}

- Block failures and bluff face steepening due to marine erosion at the base of the bluffs

- Woody debris and slush was tossed up and over the bluff edge onto the edge of the road by waves

- Wave notching/undercutting observed at bluff toe

- Upper shoreface is not covered by thick layer of ice, the shoreface is exposed

- Two gravel-rich ice ridges have formed on the lower shoreface

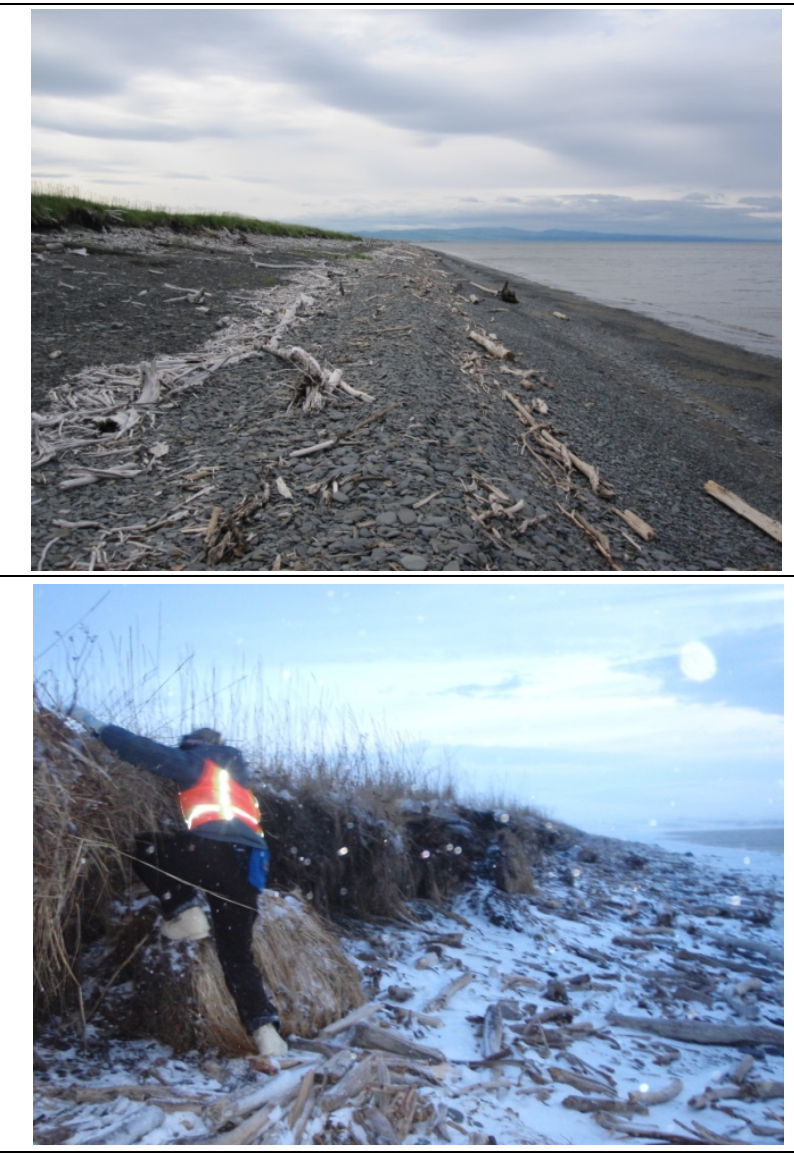

\section{Other Notes:}

This resurveyed profile is discussed in more detail in the report. 


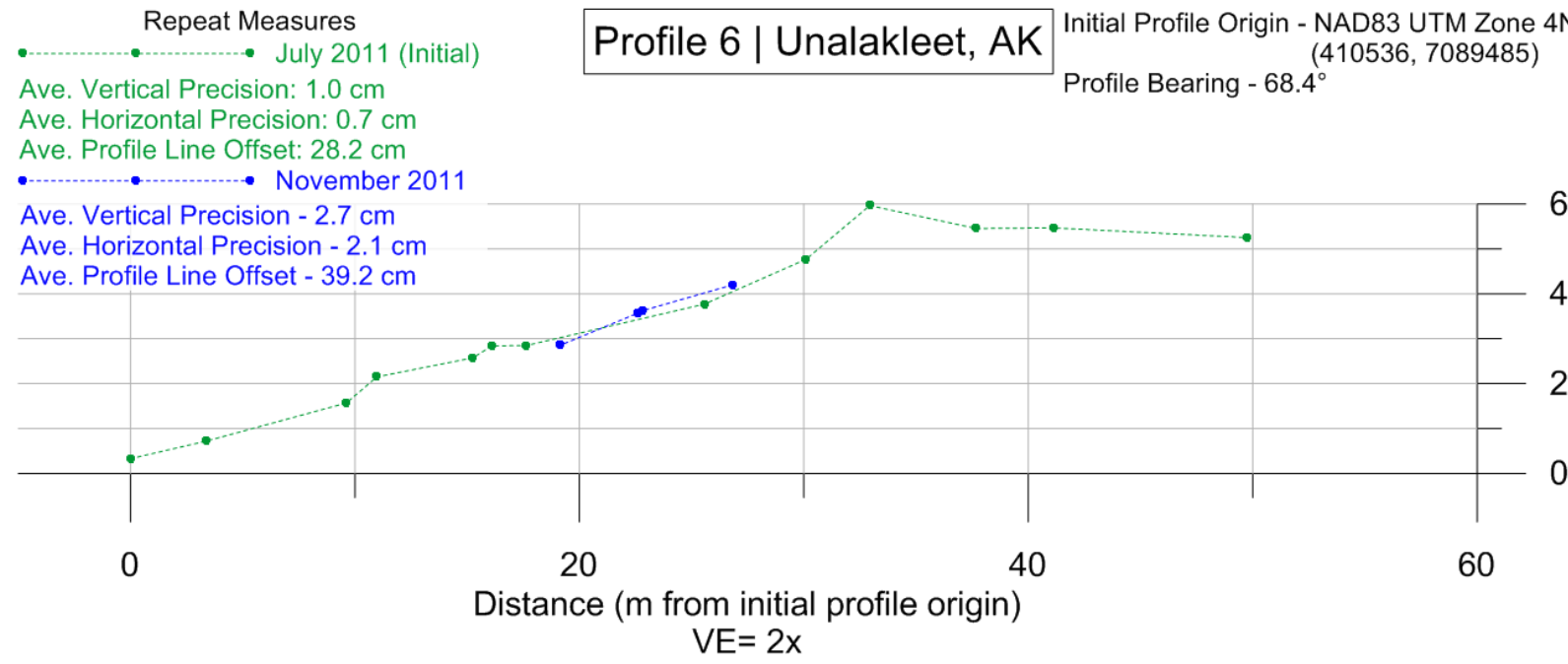

Ave. Profile Line Offset $-39.2 \mathrm{~cm}$

\section{Profile Setting:}

Located $4.5 \mathrm{~km}$ north of the Unalakleet airport, just north of the barge landing site. Profile extends from Norton Sound across the road that leads north to Powers Creek. The backbeach is characterized by a tall driftwood debris deposit.

\section{July 2011 Notes:}

- Poorly-developed gravel horns/beach cusps on lower shoreface

- Low and poorly-developed gravel berm on the mid shoreface

- Large, woody debris across the entire upper half of the shoreface

- Patch of beach peas and grass on upper shoreface fronting tall line of woody debris at backbeach

\section{November 2011 Notes:}

- Limited/no overtopping or beaching of the backbeach woody debris line occurred

- Woody debris and rounded ice chunks limited to upper shoreface only

- One ice ridge is present on the lower mid shoreface

- Wide bands of accreted slush in the intertidal region

\section{Other Notes:}

The November profile is incomplete; the number of measured locations along profile 6 is small because of a processing failure at several points along the profile, likely due to an inadequate satellite lock between the rover and base receivers. 


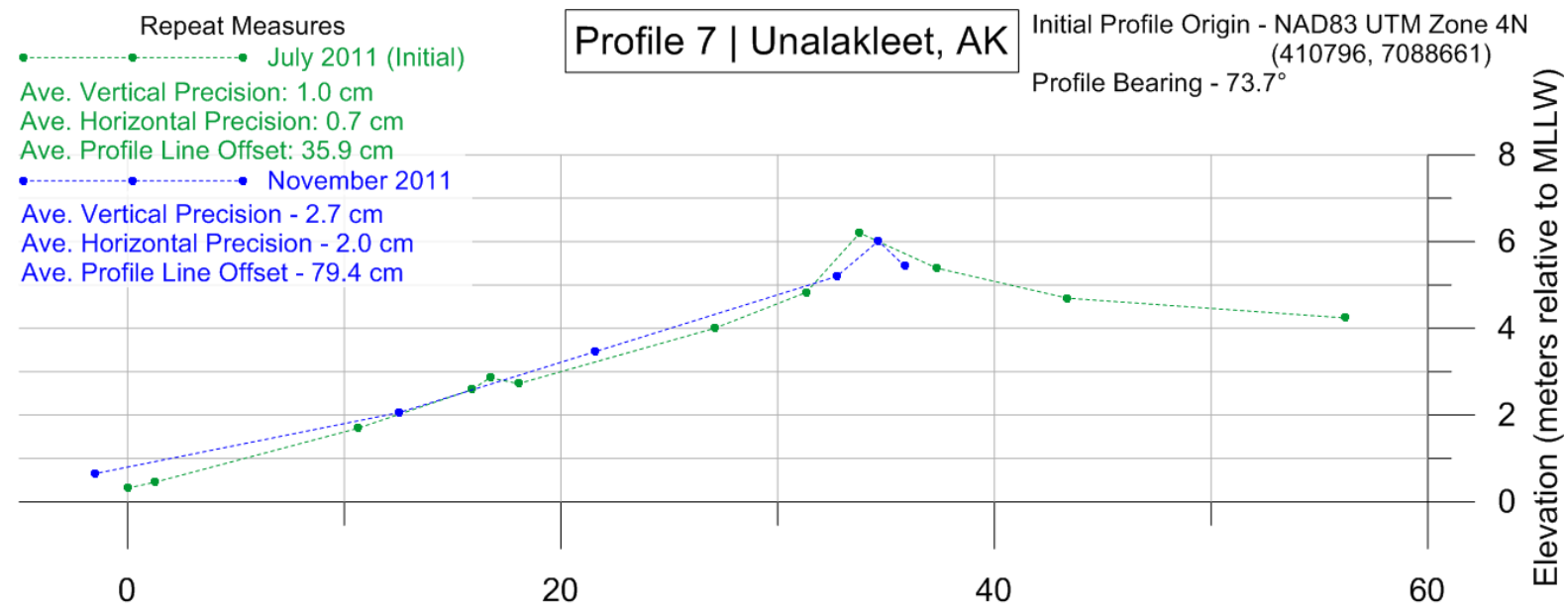

Distance ( $m$ from initial profile origin)

$\mathrm{VE}=2 x$

\section{Profile Setting:}

Located $3.6 \mathrm{~km}$ north of the Unalakleet airport, north of the bridge across Kouwegok Slough. Profile extends from Norton Sound to/across the road that leads north to the barge site and Powers Creek. The backbeach is characterized by a low, woody debris deposit atop a vegetated gravel ridge.

\section{July 2011 Notes:}

- Sand lens present atop gravel on the lower shoreface along the ATV trail

- Low and poorly-developed gravel berm on the mid shoreface

- Woody debris across the entire upper half of the shoreface to vegetation line

- Dense/wide patch of beach peas and grass on upper shoreface fronting low, woody debris line

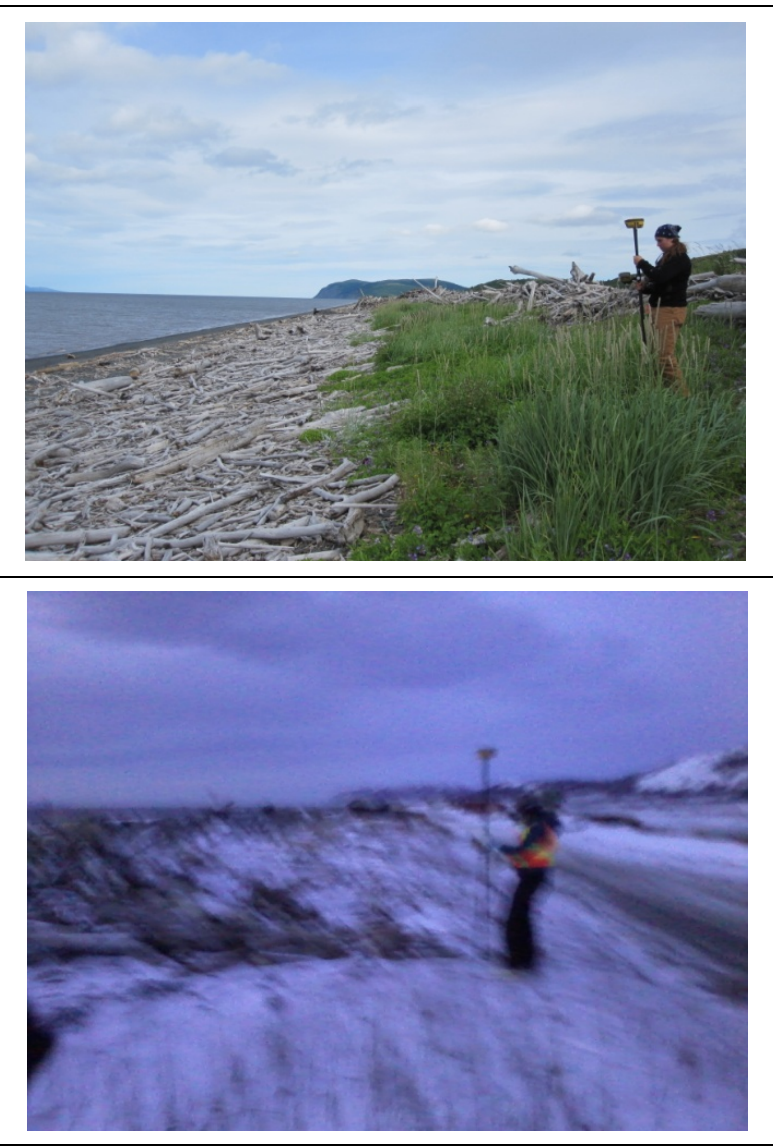

\section{November 2011 Notes:}

- Low, woody debris line at backbeach was overtopped and partially breached during storm

- Woody debris moved upslope in the storm, extending from mid shoreface to base of low, woody debris line on backbeach ridge

- Low, cuspate ice ridge just above accreted bands of slush in the intertidal

\section{Other Notes:}

None 


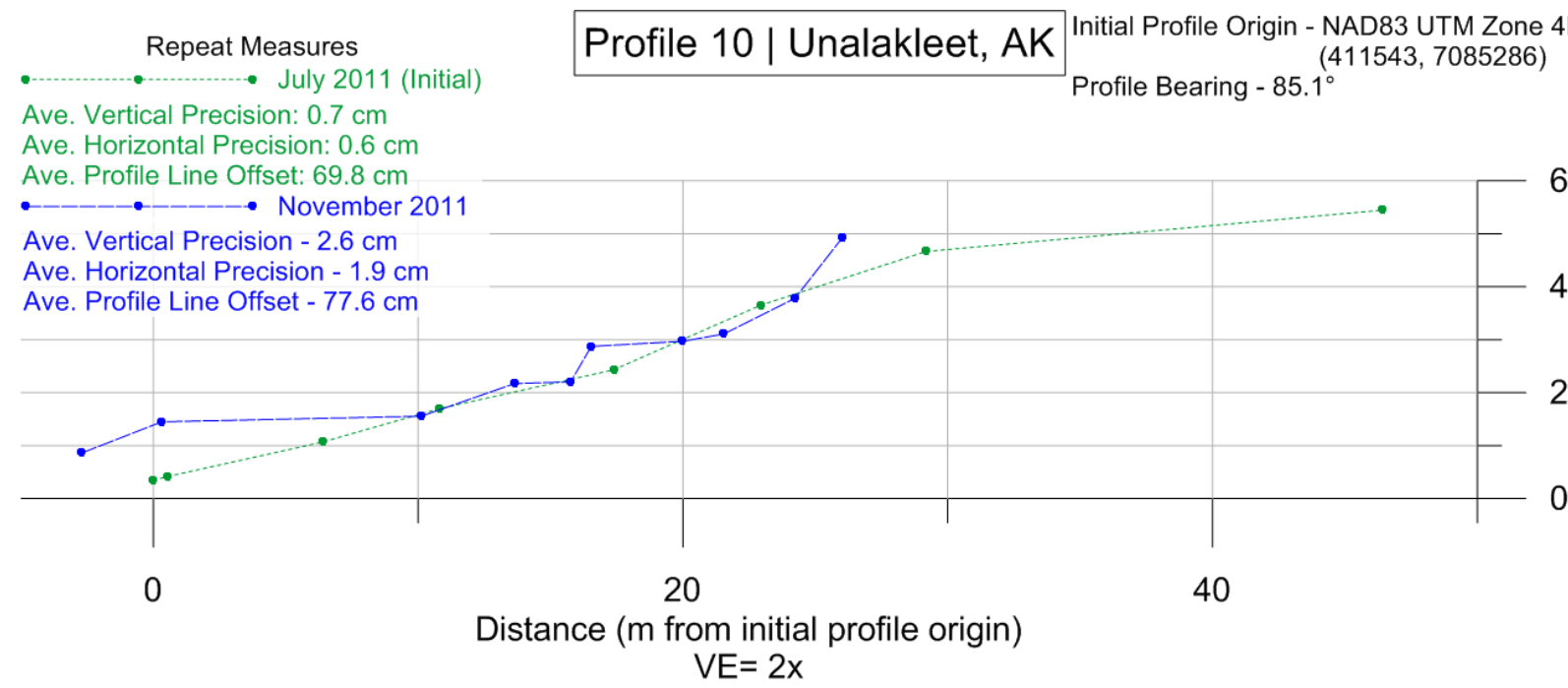

\section{Profile Setting:}

Located at the seaward end of Runway 26 in front of an armor rock revetment north of the dynamically stable engineered beach project. Profile extends from Norton Sound to the paved runway threshold. The airport fence is discontinuous at this location.

\section{July 2011 Notes:}

- Locally quarried rip rap forms a revetment at the end of the runway

- Fine-grained sediment has been pushed up and placed on top of low half of revetment by a bulldozer

- Some large, woody debris is strewn at the base of the revetment

- Sand lenses are present on the lower shoreface along the ATV trail

\section{November 2011 Notes:}

- Log-sized woody debris was deposited on paved runway threshold during storm

- Convex profile of armor rock suggests some slumping of the revetment occurred

- Large ice ridge present at the base of the revetment

- Ice blocks and logs on the lower shoreface are pushed up against the ice ridge

- Cuspate bands of accreted slush in the intertidal region
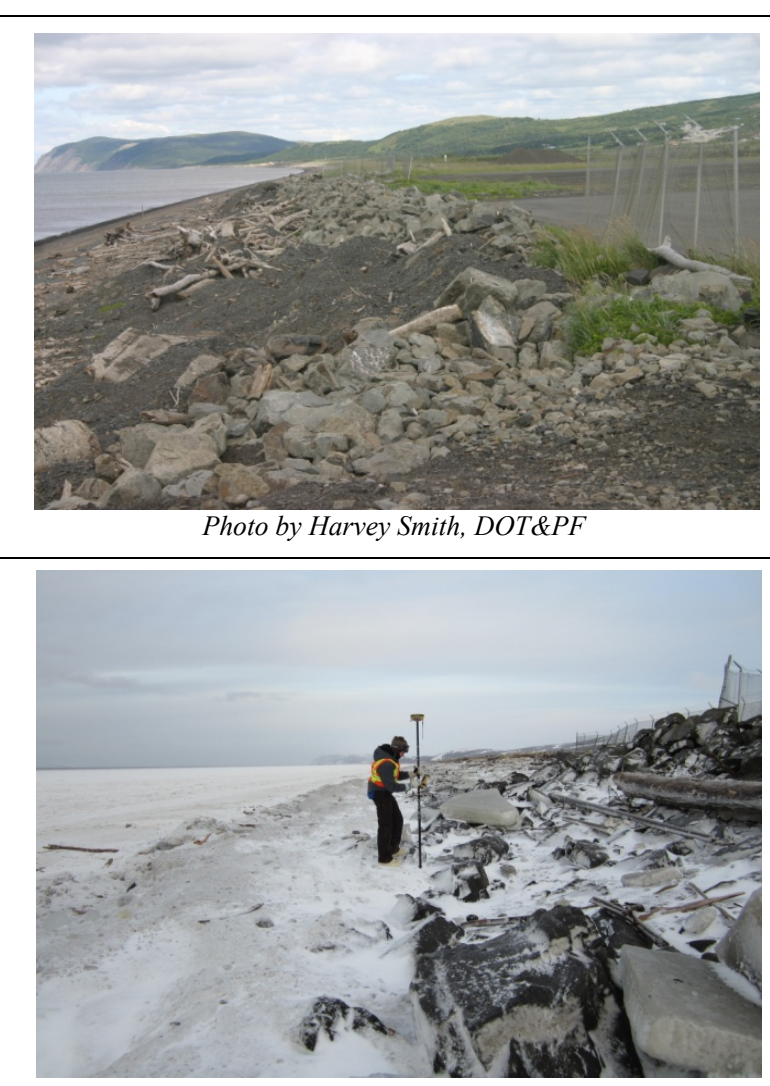

\section{Other Notes:}

Additional armor rock was emplaced at this location on top of the finer-grained fill prior to Fall 2011. The effects of this addition are visible in the measured profiles and in the appearance of the revetment. Some debris had been cleared from the paved runway surface and pushed onto the revetment by work crews prior to the post-storm measurements. The complete summer profile includes offshore bathymetry at this location. 


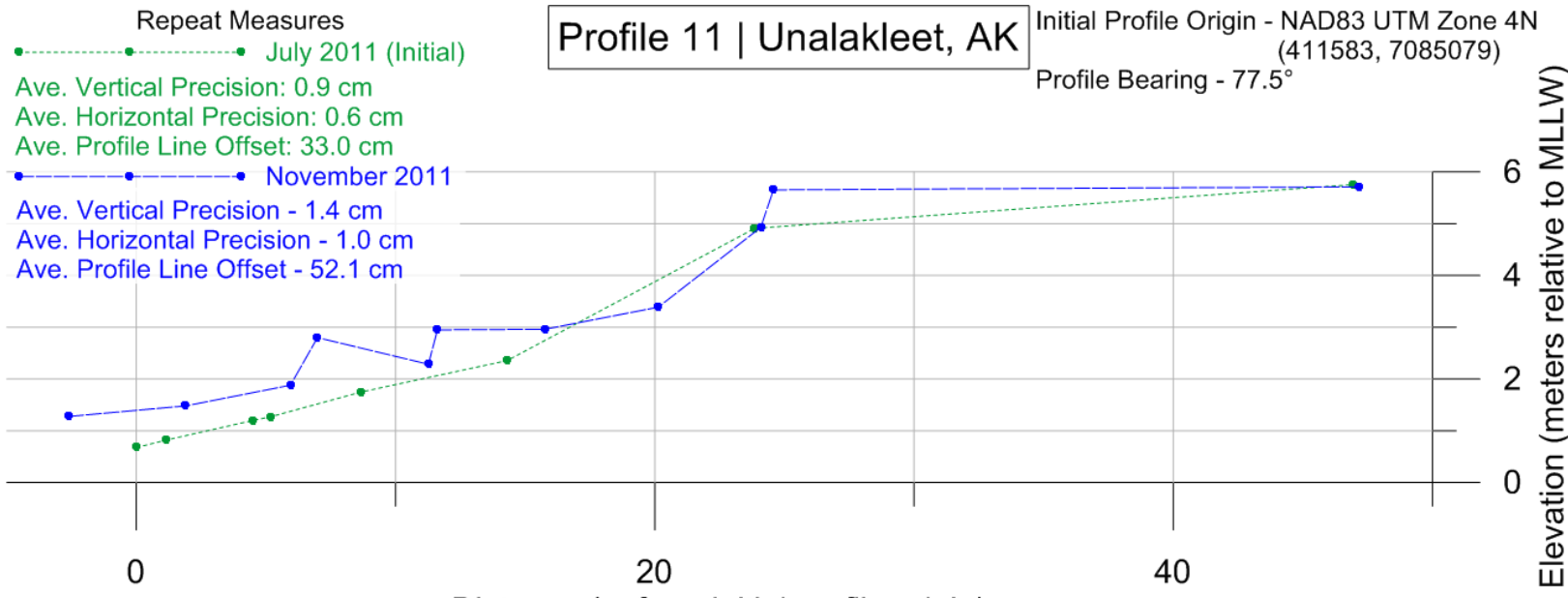

Distance ( $m$ from initial profile origin)

$\mathrm{VE}=2 \mathrm{x}$

\section{Profile Setting:}

Located next to the main building at the DOT\&PF-engineered beach project. Profile extends from Norton Sound to the parking area next to the airport building. Concrete barriers atop the revetment mark the outer edge of the parking area.

\section{July 2011 Notes:}

- Dynamically stable beach (engineered by DOT\&PF)

- Parking area extends onto crest of engineered portion of beach

- Fine-grained material has been added to the face of the engineered beach project by a bulldozer

- Some minor woody debris is strewn at the base of the revetment

- Sand lenses are present on the lower shoreface along the ATV trail

\section{November 2011 Notes:}

- Steepening and minor undercutting below the concrete barriers has occurred at the crest of the dynamically stable beach

- No overtopping of the crest by water or debris was observed at this profile location

- Two large ice ridges have developed on the lower shoreface

- Woody debris is all oriented parallel to shore in front of and between the ice ridges

- Linearly accreted bands of slush are present in the intertidal zone

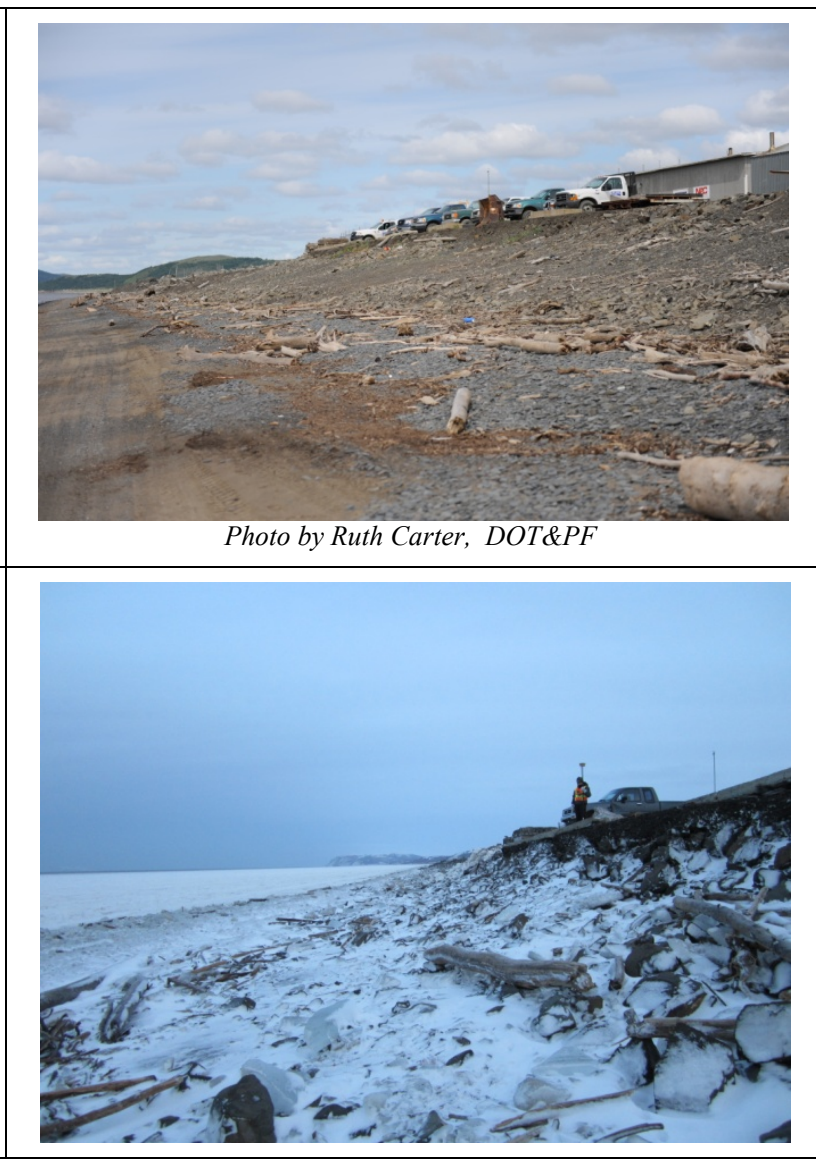

\section{Other Notes:}

The dynamically stable beach was extended seaward of the recommended design template at this location. This resurveyed profile is discussed in more detail in the report. 


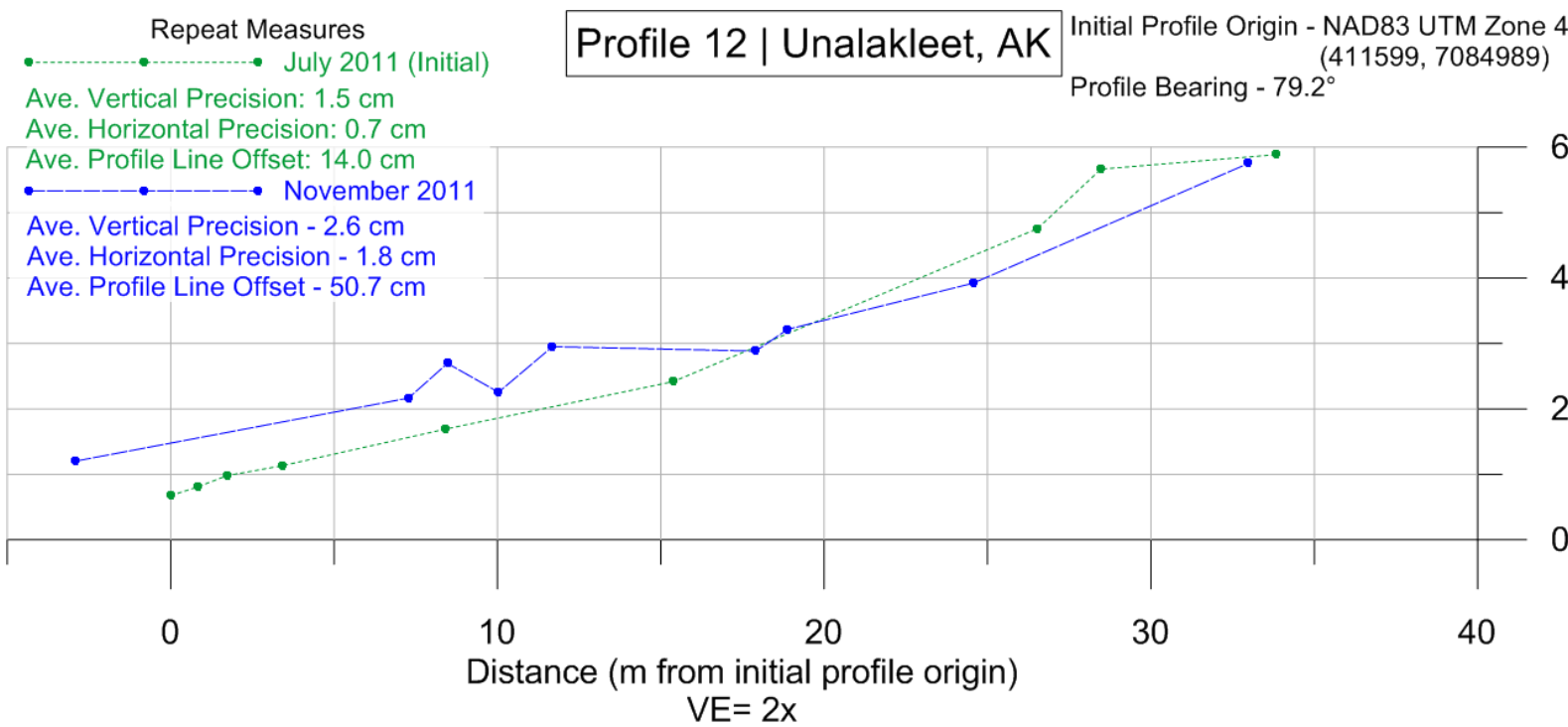

\section{Profile Setting:}

Located next to the ATS building at the dynamically stable engineered beach project. Profile extends from Norton Sound to the edge of the DOTPF road.

\section{July 2011 Notes:}

- Dynamically stable beach (engineered by DOT\&PF)

- $\quad$ Fine-grained material has been added to the face of the engineered beach project by a bulldozer

- Some minor woody debris is present on the face of the engineered beach

- Sand lenses are present on the lower shoreface along the ATV trail

\section{November 2011 Notes:}

- Woody debris from overtopping was observed at the crest of engineered beach

- Woody debris and ice chunks are evenly strewn across the mid shoreface

- Two ice ridges present on the lower shoreface

- Woody debris is all oriented parallel to shore in front of and between the ice ridges

- Linearly accreted bands of slush are present in the intertidal area

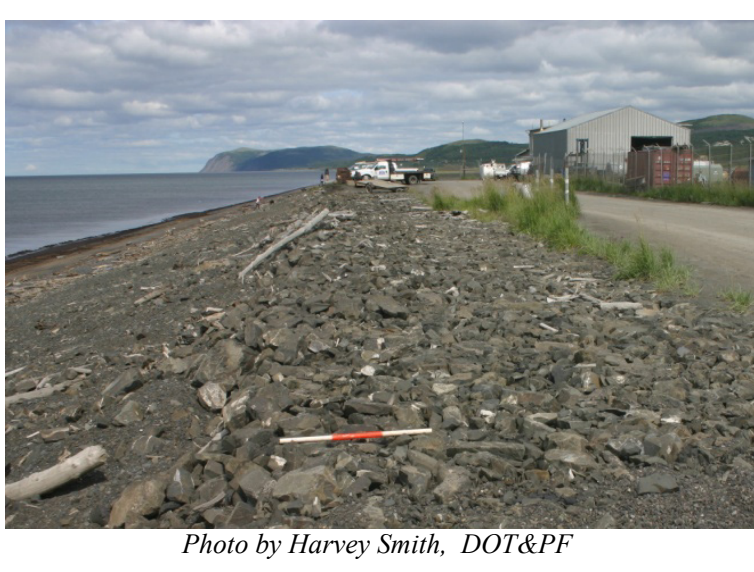

Photo by Harvey Smith, DOT\&PF

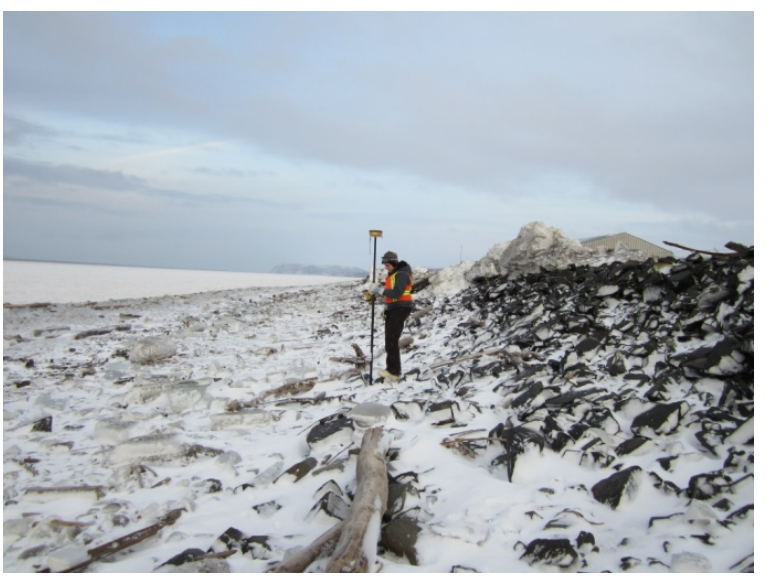

\section{Other Notes:}

This resurveyed profile is discussed in more detail in the report. 


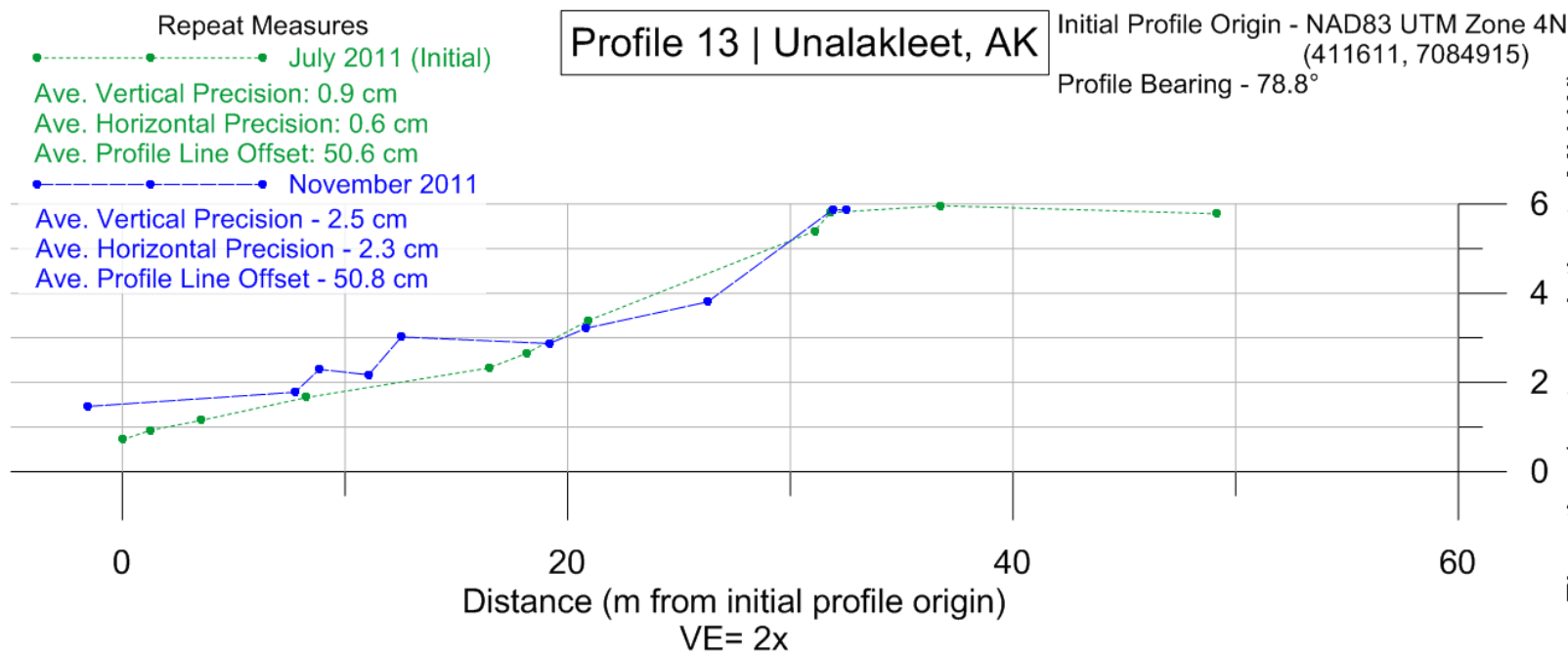

\section{Profile Setting:}

Located next to the BSSD Hanger at the dynamically stable engineered beach project. Profile extends from Norton Sound to the inland edge of the DOT\&PF road.

\section{July 2011 Notes:}

- Dynamically stable beach (engineered by DOT\&PF)

- Fine-grained material has been added to the face of the engineered beach project by a bulldozer, in some areas obscuring coarse clasts entirely

- Some minor woody debris is present on top of the fill material on the face of the engineered beach

- Sand lenses are present on the lower shoreface along the ATV trail

\section{November 2011 Notes:}

- Abundant woody debris from overtopping was observed at the crest of engineered beach, some was reportedly cleared away already

- Engineered beach slope was visibly scarped near the base and frozen blocks of finer-grained material had been deposited at the toe

- Two ice ridges present on the lower shoreface

- Woody debris is all oriented parallel to shore in front of and between the ice ridges

- Linearly accreted bands of slush are present in the intertidal

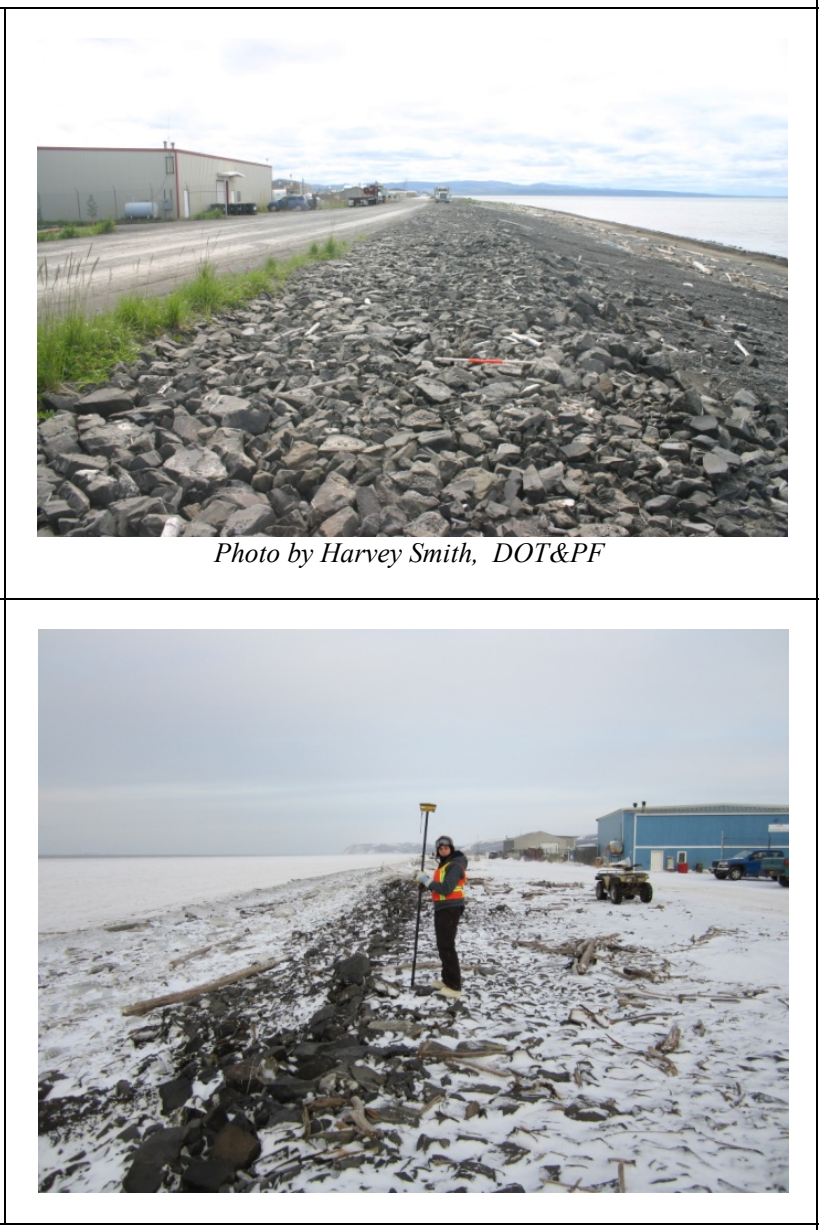

Other Notes:

This resurveyed profile is discussed in more detail in the report. 


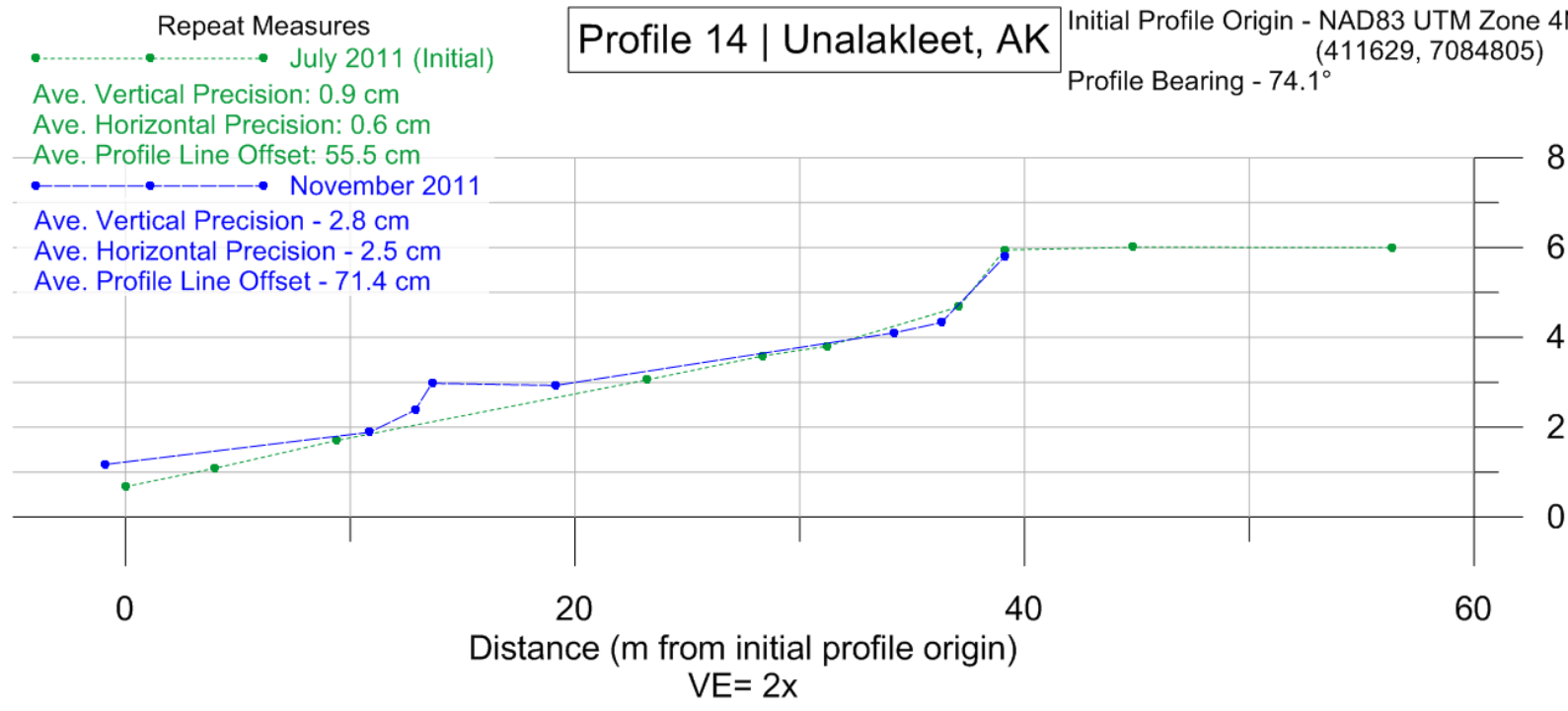

\section{Profile Setting:}

Located between the old DOT\&PF garage and the FAA building at the dynamically stable engineered beach project. Profile extends from Norton Sound to the inland edge of the DOT\&PF road and crosses an ATV access trail to the beach.

\section{July 2011 Notes:}

- Dynamically stable beach (engineered by DOT\&PF)

- Boulders are present in fine gravel at the base of the engineered portion of the beach

- Woody debris has been cleared from this area

- Some beach peas have grown next to the upper ATV trail (fine gravel)

- Sand lenses are present on the lower shoreface along the lower ATV trail

\section{November 2011 Notes:}

- Abundant storm-deposited driftwood debris was observed at the crest of engineered beach, some was reportedly cleared away before our observation

- Large blocks of ice and some woody debris deposited near toe of engineered beach slope

- Two ice ridges present on the lower shoreface

- Linearly accreted bands of slush are present in the intertidal region

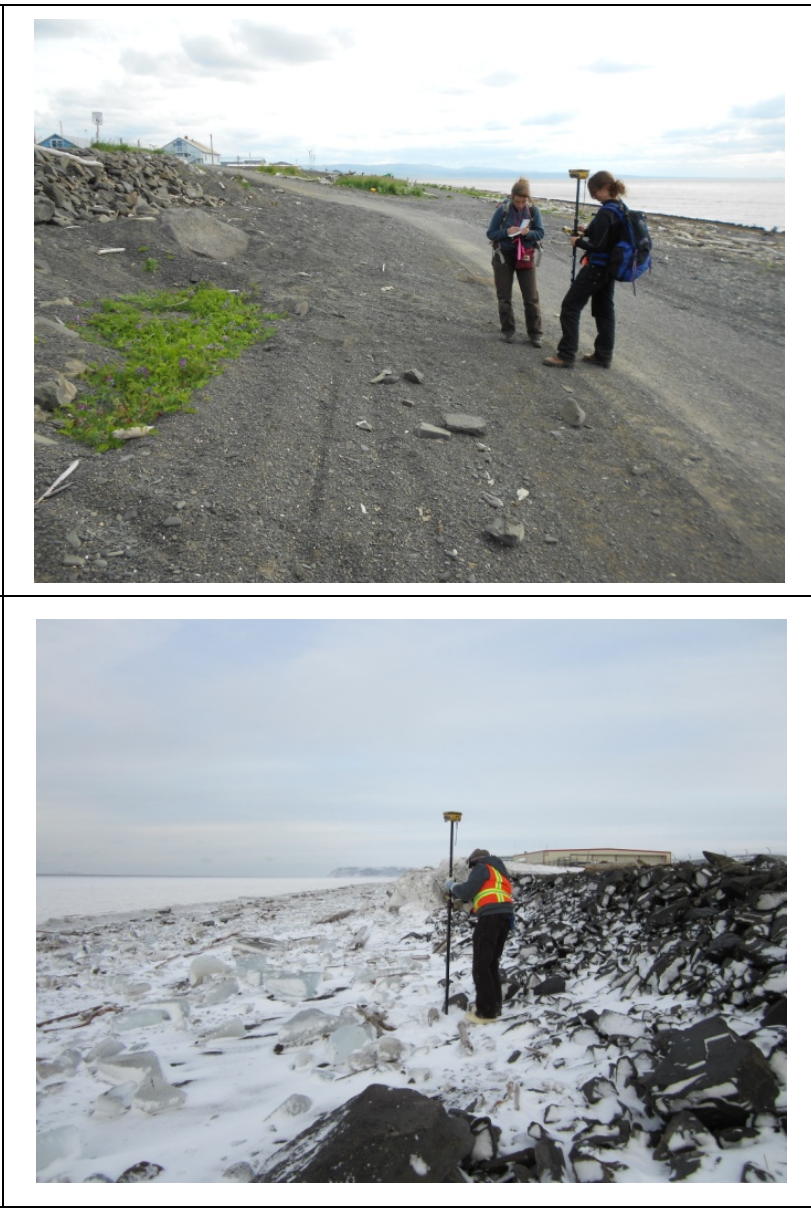

Other Notes:

This resurveyed profile is discussed in more detail in the report. 


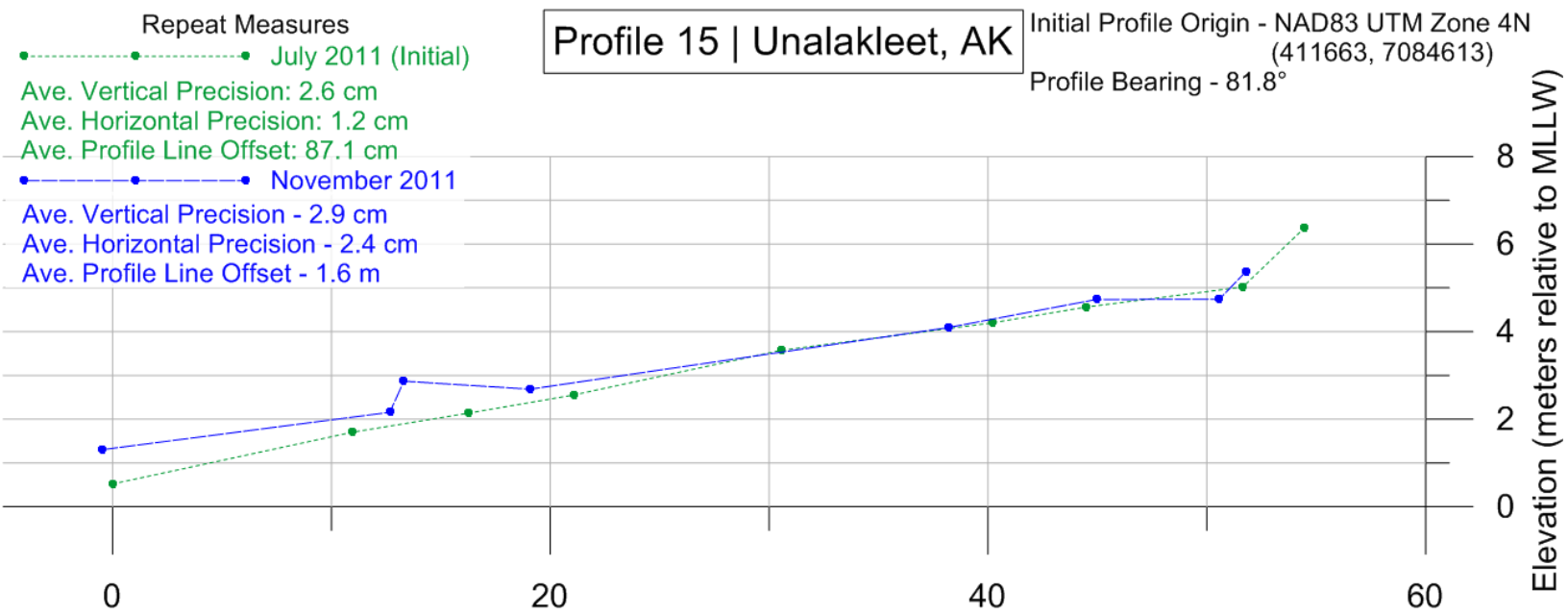

Distance ( $m$ from initial profile origin)

$\mathrm{VE}=2 \mathrm{x}$

\section{Profile Setting:}

Located next to the BSSD garage. Profile extends from Norton Sound to the seaward edge of Beach West Road.

\section{July 2011 Notes:}

- A mid-beach line of coarse gravel is present but a berm has not formed

- The mid-upper shoreface is sparsely vegetated by beach peas and grass

- A woody debris line, mixed with minor vegetation, is present along the base of the graded road

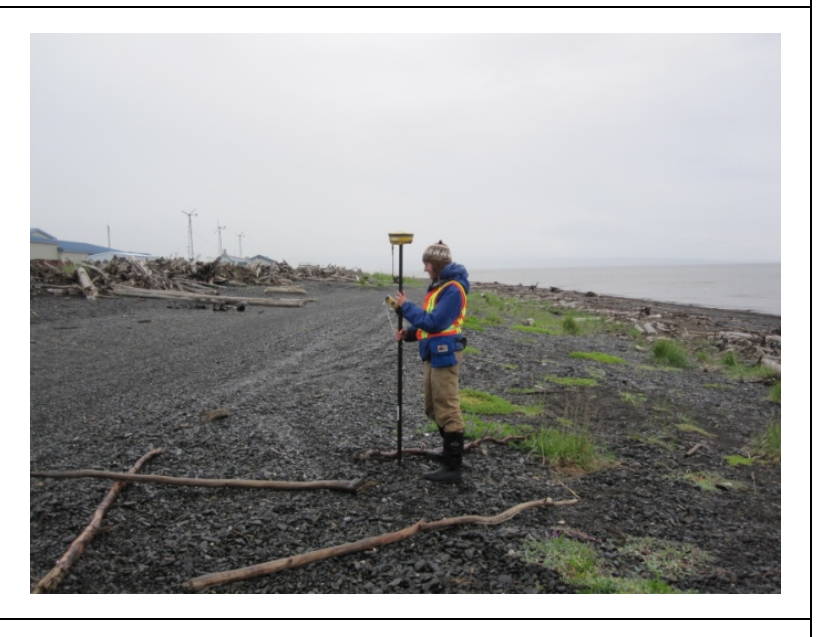

\section{November 2011 Notes:}

- Slush and small, woody debris deposited by runup on slope of the graded road surface

- Large, woody debris line present along base of roadway

- At location of profile, a woody debris line was breached and large volumes of coarse sand and slush were deposited on the upper shoreface

- Ice ridge present on lower shoreface

- Woody debris is all oriented parallel to shore in front of the ice ridge

- Linearly accreted bands of slush are present in the intertidal zone

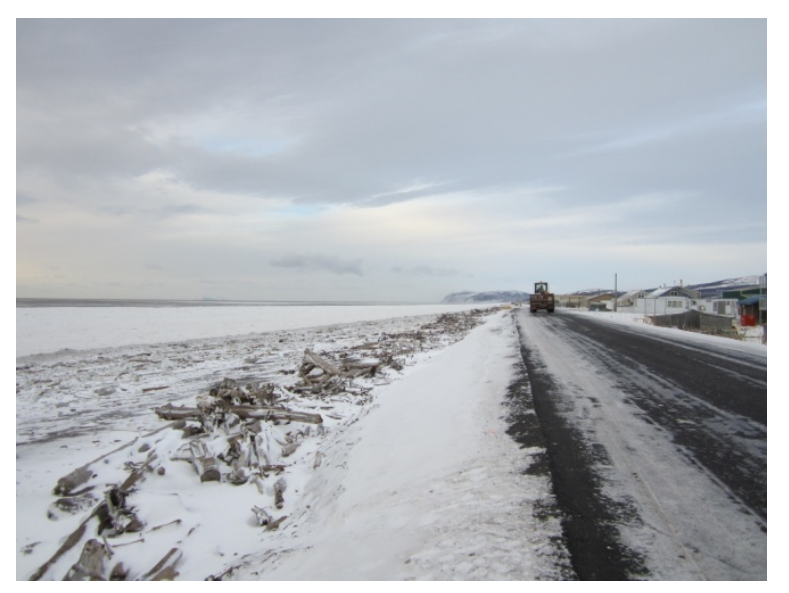

\section{Other Notes:}

See Figure 9a in report for example of a runup line collected along this profile on the road grade. 


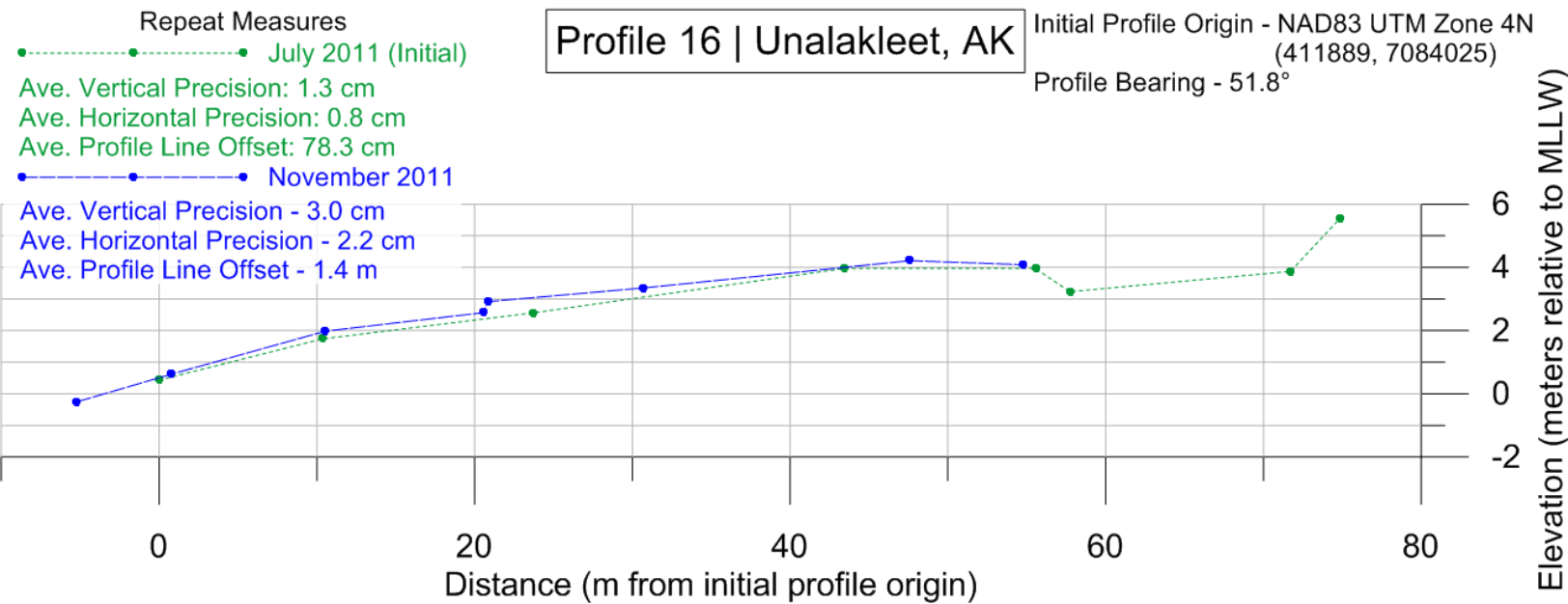

$\mathrm{VE}=2 \mathrm{x}$

\section{Profile Setting:}

Located near the inlet mouth, $100 \mathrm{~m}$ north from the end of the U.S. Army Corps of Engineers (USACE) revetment. Profile extends from Norton Sound to the seaward edge of the raised Beach Road.

\section{July 2011 Notes:}

- Wide, low-angle beach composed primarily of coarse sand

- Woody debris present on the lower shoreface just above the intertidal zone

- Low area adjacent to the raised road is filled with beach grasses and log-sized woody debris

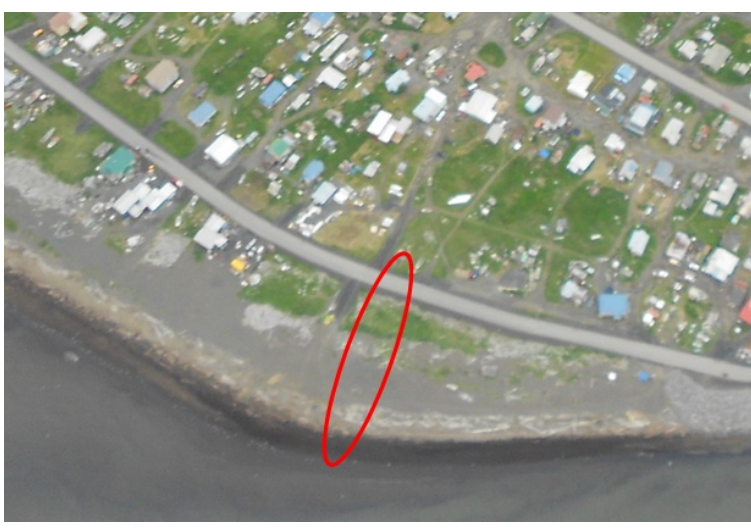

\section{November 2011 Notes:}

- Stable vegetation inland of remeasured portion of profile, adjacent to the raised road

- Fish-drying racks in area were not damaged even though they were inundated at the base

- Abundant jumbled ice and woody debris present across entire remeasured profile

- Minor ice ridge present on the mid shoreface

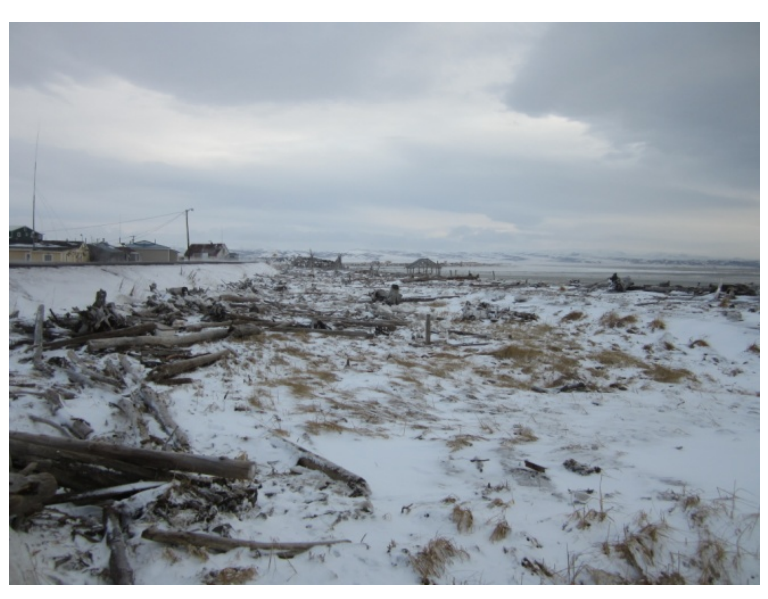

\section{Other Notes:}

None 


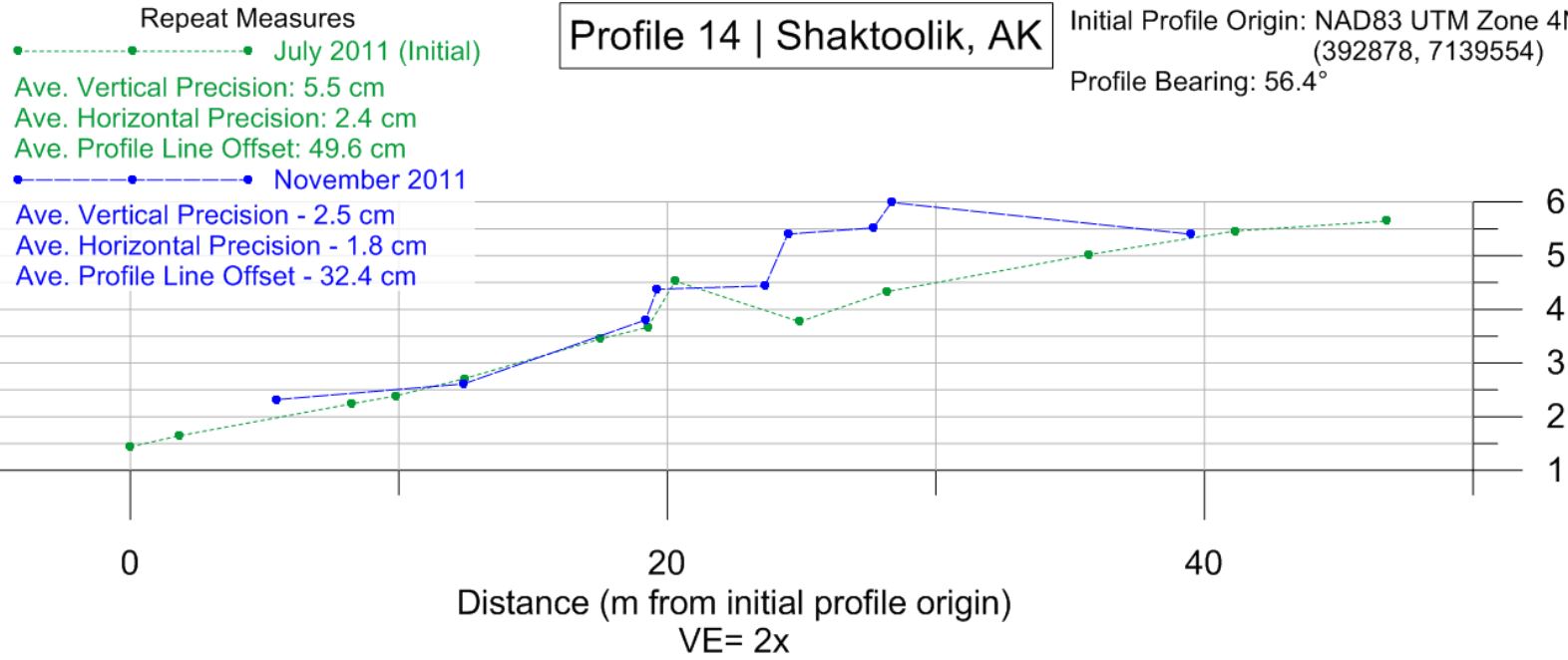

\section{Profile Setting:}

Located next to the runway and apron near the airport building. Profile extends from Norton Sound to the inland extent of woody debris observed on the berm adjacent to the runway surface.

\section{July 2011 Notes:}

- Mid-profile berm is capped by a large amount of log-sized woody debris

- Woody debris present from crest of lower berm to area below the runway surface

- Sparse vegetation (grasses) present in area inland from lower berm

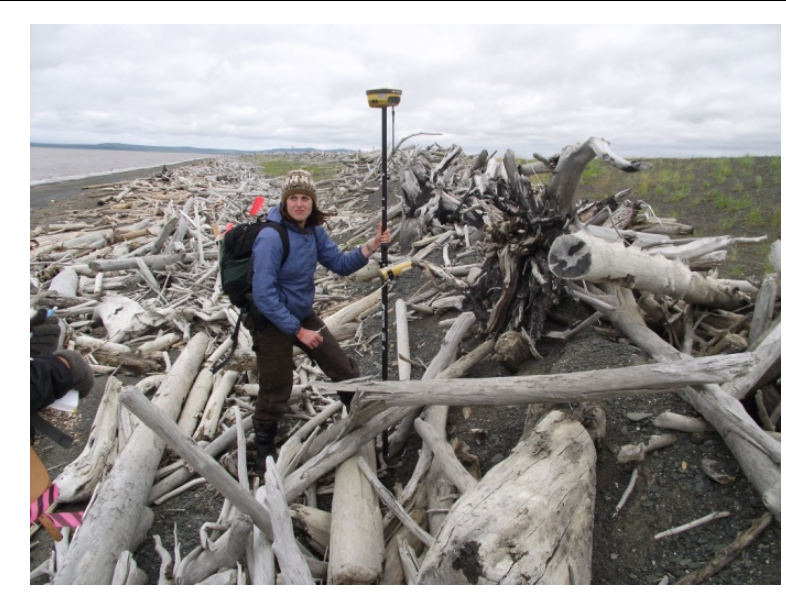

\section{November 2011 Notes:}

- $\quad$ Large quantities of slush were washed up and frozen atop pre-existing woody debris

- Area between lower berm and edge of runway surface is filled with drifted snow and ice

- Multiple generations of steep ice and slush ridges present across the profile

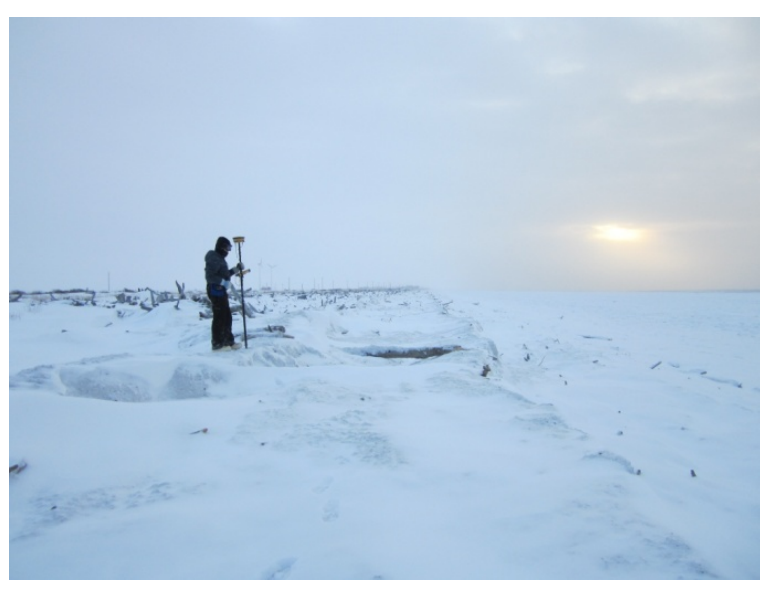

\section{Other Notes:}

Complete summer profile includes more measured elevations farther inland. 


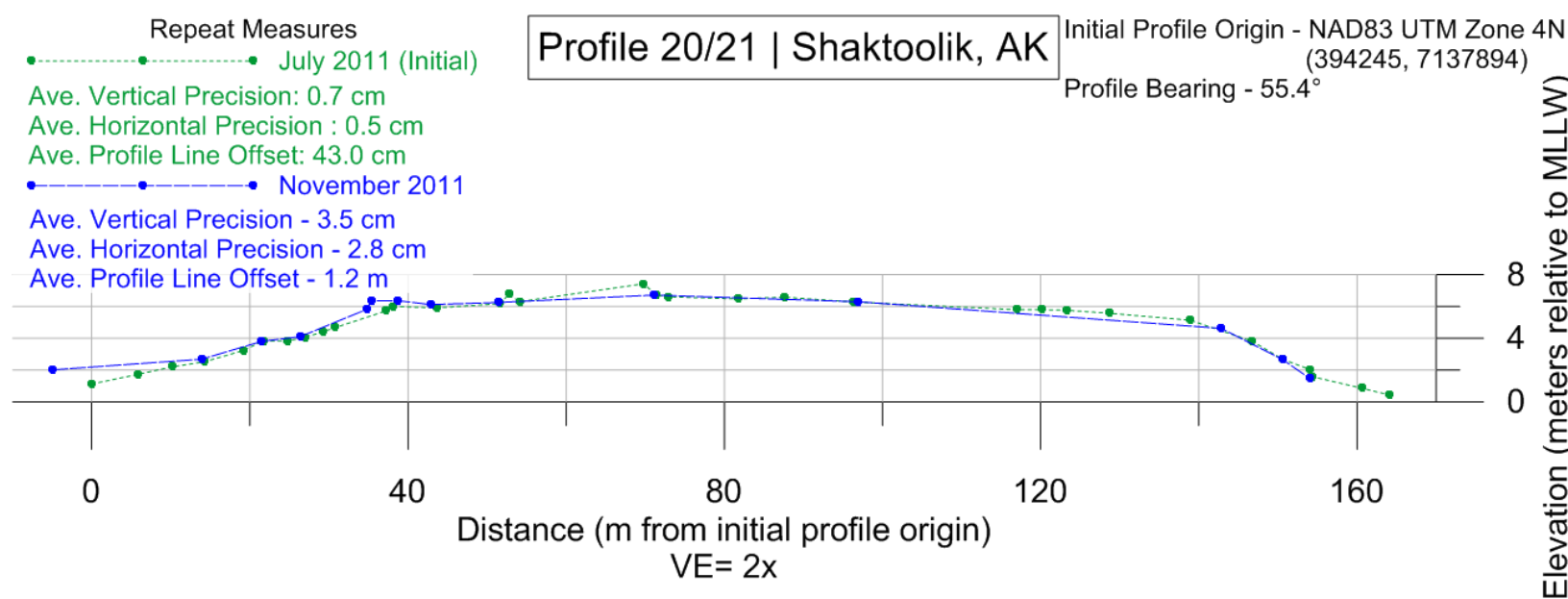

\section{Profile Setting:}

Located next to the tank farm and adjacent to the community. Profile extends from Norton Sound across the barrier spit to the bank of Tagoomenik River.

\section{July 2011 Notes:}

- Sand lenses present on the lower shoreface along the lower ATV trail

- Two lines of woody debris on the upper shoreface; one sits atop a lower berm and one caps the upper berm directly in front of the tank farm

- Beach peas and grasses present between the woody debris lines

- Tank farm is surrounded by a low levee of sandbags and geotextile material

- Edge of Tagoomenik River is well vegetated by grasses, with a narrow, sandy beach at the base of a $<1 \mathrm{~m}$ scarp in the riverbank

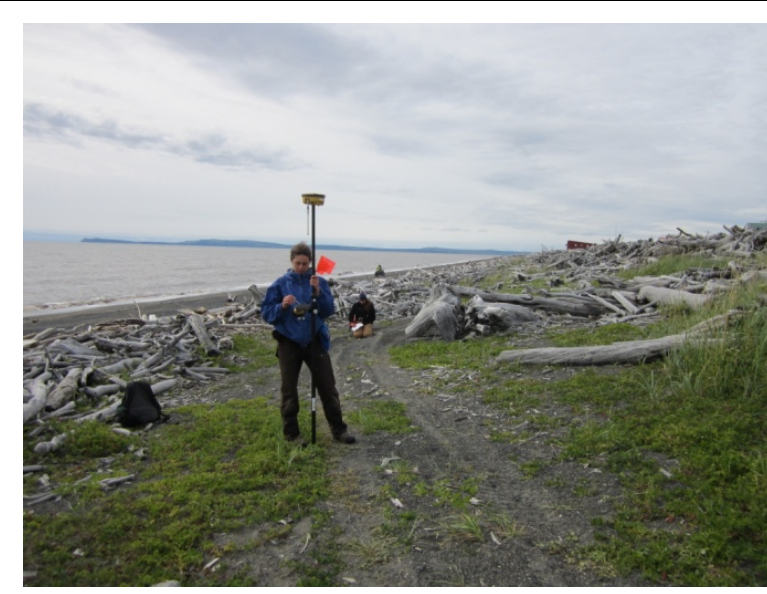

\section{November 2011 Notes:}

- Low ice and frozen slush ridge with a stepped surface present at front edge of upper woody debris line

- Lower woody debris line is no longer present

- Waves did not overtop the upper woody debris line at this location; runup of slush is visible below snow cover

- Shoulder of Tagoomenik River bank is heavily drifted over by snow that has an icy crust that is difficult to penetrate

- Tagoomenik River is slushy and covered with large floating pieces of ice

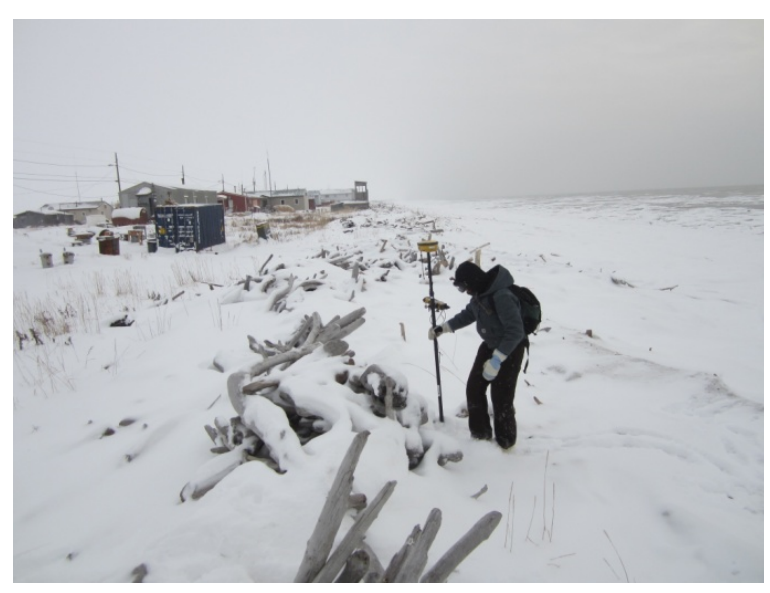

\section{Other Notes:}

The engineered berm surrounding the tank farm was not remeasured in November 2011.

This resurveyed profile is discussed in more detail in the report. 


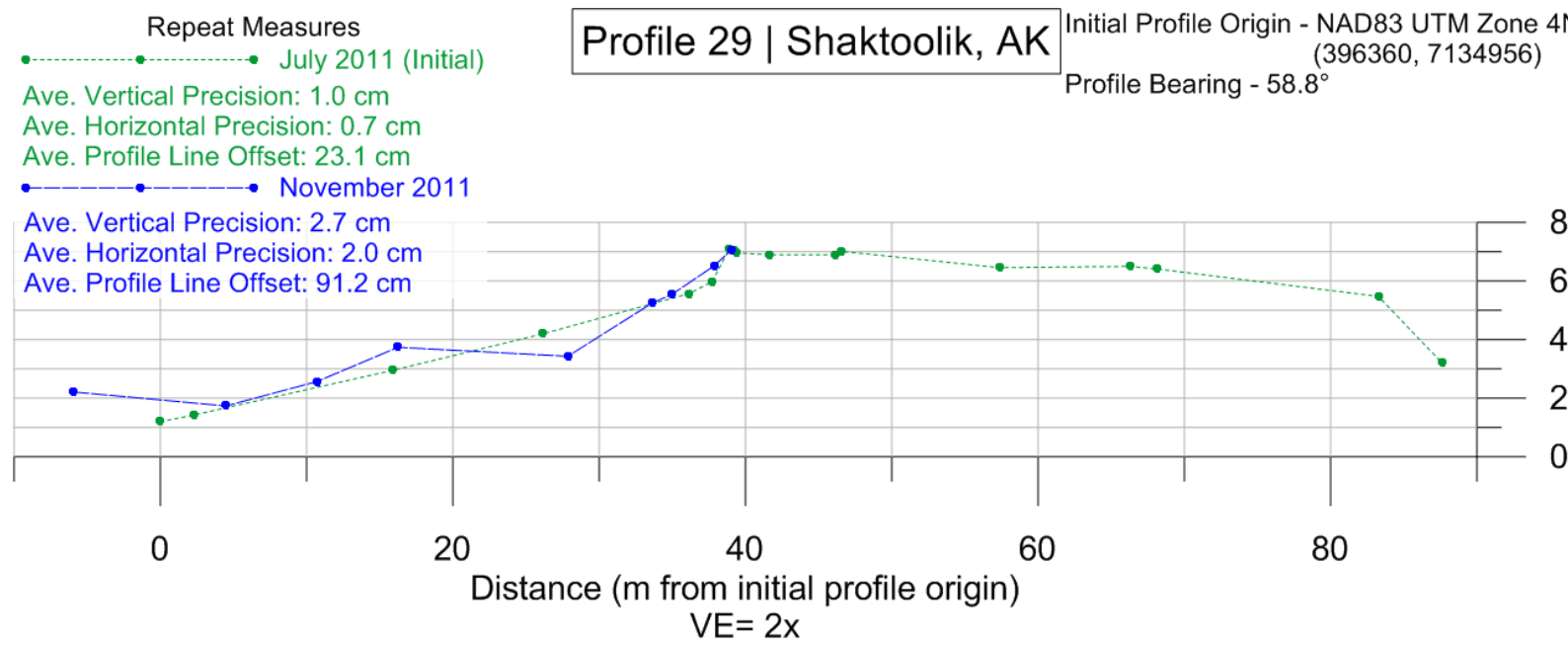

\section{Profile Setting:}

Located next the old runway at the former community site. Profile extends from Norton Sound to the bank of Tagoomenik River.

\section{July 2011 Notes:}

- Well-developed gravel horns and beach cusps

- Abundant large, woody debris on entire upper half of shoreface

- Debris toe with sparse vegetation at base of low, eroding gravel bluff

- Woody debris had been deposited atop low bluff and across old runway

- Bank of Tagoomenik River is steep and densely covered by low willows

\section{November 2011 Notes:}

- Extensive slush and woody debris overwash $2 \mathrm{~m}$ north of profile location

- Wood debris and frozen slush pushed up against the low bluff at the backbeach

- Less woody debris on the upper shoreface than was seen at this location in the summer

- Low ice ridge containing lots of gravel on the mid shoreface

- Slush ridges containing logs are present in the intertidal zone
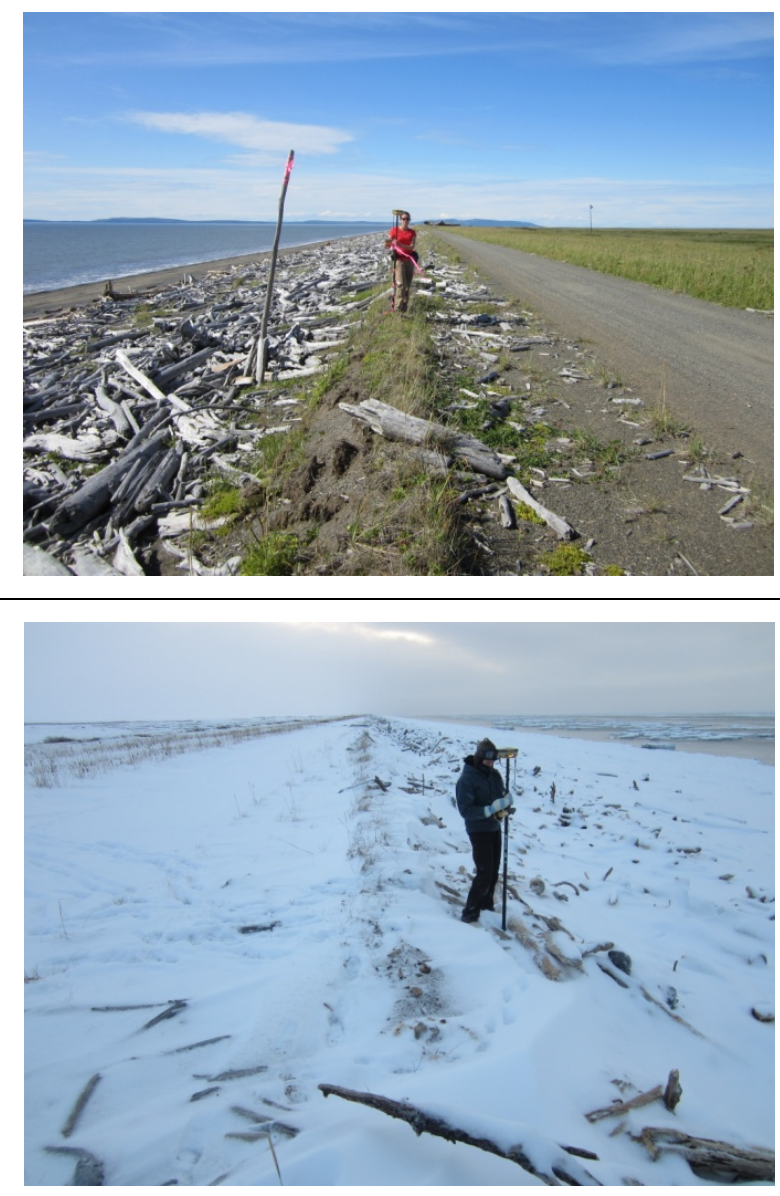

\section{Other Notes:}

Complete summer profile includes offshore bathymetry. 


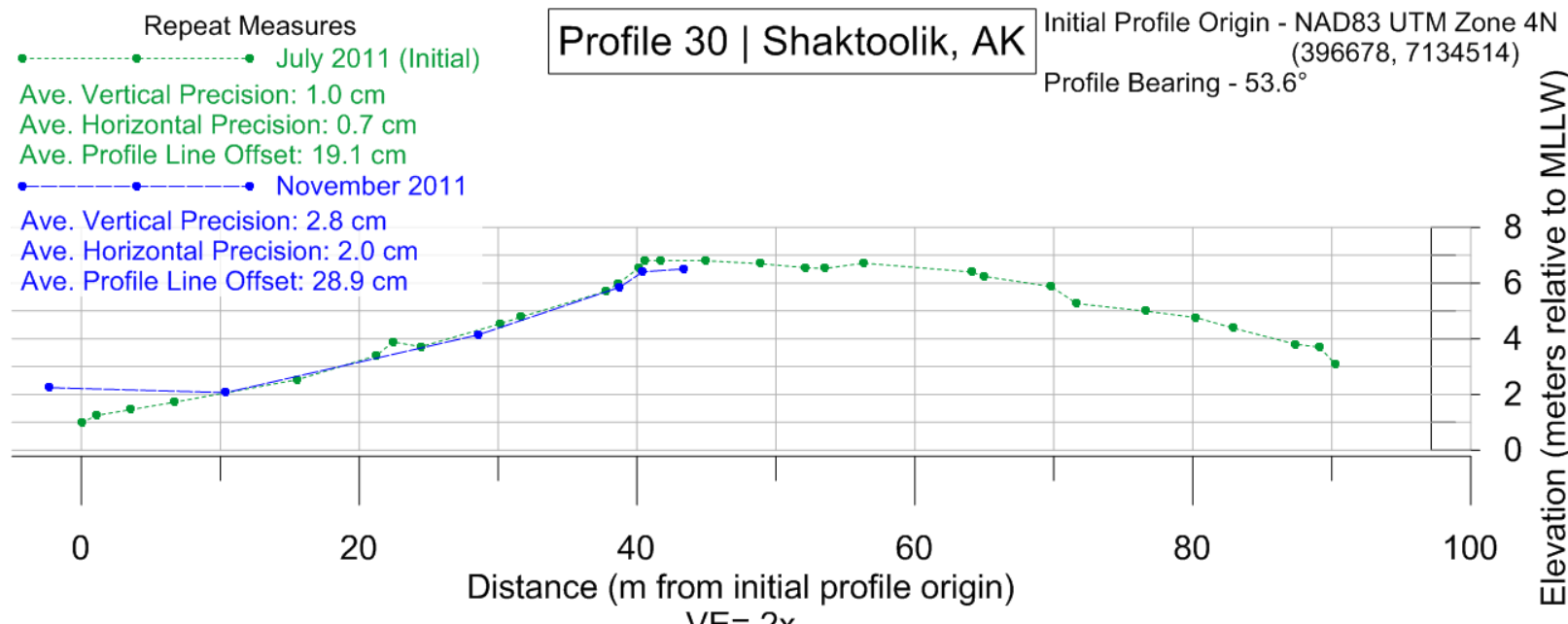

$\mathrm{VE}=2 \mathrm{x}$

\section{Profile Setting:}

Located next the old runway at the former community site and near an ATV access trail to the beach. Profile extends from Norton Sound to a low floodplain adjacent to Tagoomenik River.

July 2011 Notes:

- Well-developed gravel horns and beach cusps

- Low gravel berm present at the mid shoreface

- Abundant large, woody debris on entire upper half of shoreface

- Debris toe with sparse vegetation at base of low, eroding gravel bluff

- Woody debris observed on inland side of old runway

- Floodplain is grassy with patches of shrubby willow and birch

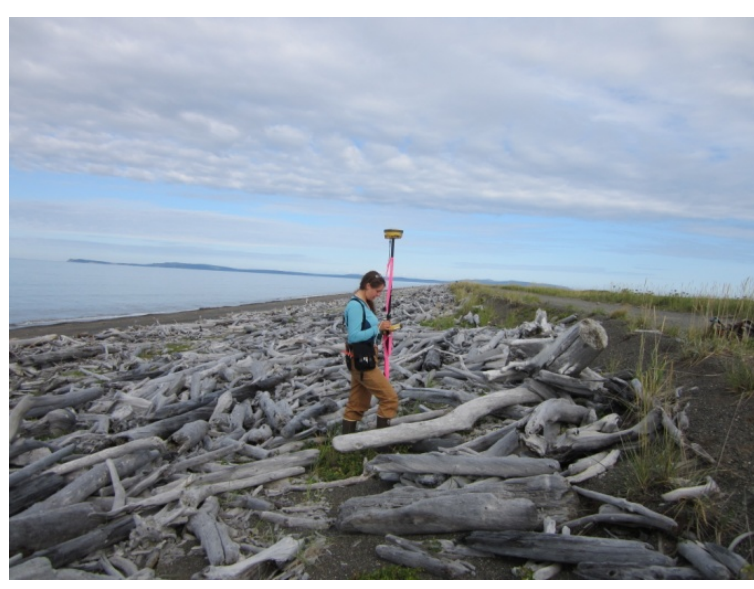

\section{November 2011 Notes:}

- Additional woody debris has been deposited atop the old runway surface

- No horizontal retreat of the low bluff observed

- Less woody debris on the upper shoreface than was seen at this location in the summer

- Slush and ice ridges are present in the intertidal area

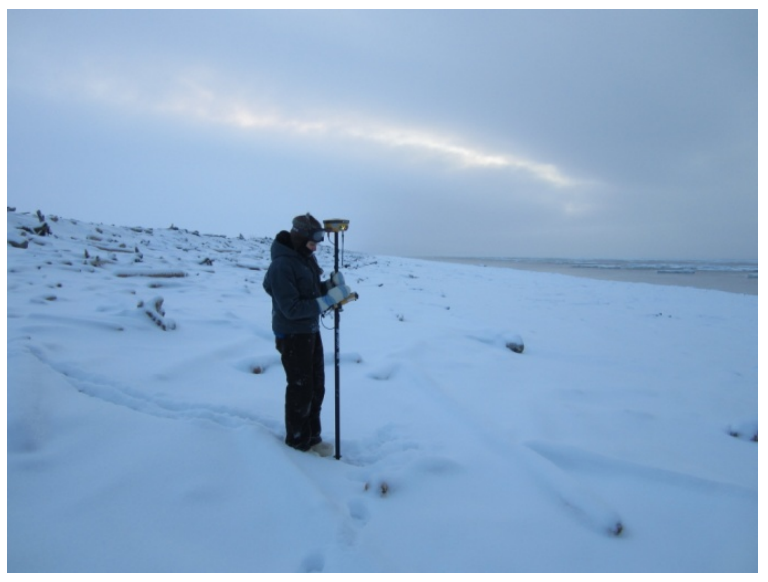

\section{Other Notes:}

Snow cover obscured the full extent of woody debris deposited atop the old runway during the November 2011 storm. 



\section{Appendix C}

\section{Archived data from National Data Buoy Center Station 46035 - BERING SEA 310 NM North of Adak, AK}

Available online at: http://www.ndbc.noaa.gov/station page.php?station=46035

Buoy location: $\quad 57.067^{\circ} \mathrm{N} 177.750^{\circ} \mathrm{W} \quad$ or $\quad 57^{\circ} 4^{\prime} 0^{\prime \prime} \mathrm{N} 177^{\circ} 45^{\prime} 0^{\prime \prime} \mathrm{W}$

\begin{tabular}{|c|c|c|c|c|c|c|c|c|c|c|c|c|c|c|c|c|c|}
\hline $\begin{array}{c}\# Y Y \\
y r\end{array}$ & $\begin{array}{l}\text { MM } \\
\text { mo }\end{array}$ & $\begin{array}{l}\text { DD } \\
\text { dy }\end{array}$ & $\begin{array}{l}\mathrm{hh} \\
\mathrm{hr}\end{array}$ & $\begin{array}{c}\mathrm{mm} \\
\mathrm{mn}\end{array}$ & $\begin{array}{l}\text { WDIR } \\
\text { degT }\end{array}$ & $\begin{array}{l}\text { WSPD } \\
\mathrm{m} / \mathrm{s}\end{array}$ & $\begin{array}{l}\text { GST } \\
\mathrm{m} / \mathrm{s}\end{array}$ & $\begin{array}{c}\text { WVHT } \\
\mathrm{m}\end{array}$ & $\begin{array}{l}\text { DPD } \\
\text { sec }\end{array}$ & $\begin{array}{l}\text { APD } \\
\text { sec }\end{array}$ & $\begin{array}{l}\text { MWD } \\
\operatorname{deg} T\end{array}$ & $\begin{array}{l}\text { PRES } \\
\mathrm{hPa}\end{array}$ & $\begin{array}{l}\text { ATMP } \\
\operatorname{degC}\end{array}$ & $\begin{array}{l}\text { WTMP } \\
\operatorname{deg} C\end{array}$ & $\begin{array}{l}\text { DEWP } \\
\operatorname{deg} C\end{array}$ & $\begin{array}{l}\text { VIS } \\
\mathrm{mi}\end{array}$ & $\begin{array}{c}\text { TIDE } \\
\mathrm{ft}\end{array}$ \\
\hline 2011 & 11 & 08 & 19 & 50 & 166 & 24.1 & 32.7 & 7.43 & 11.43 & 8.38 & 999 & 970.1 & 999.0 & 999.0 & 999.0 & 99.0 & \\
\hline 2011 & 11 & 08 & 0 & 50 & 175 & 25.1 & 32.3 & 9.69 & 12.12 & 9.32 & 999 & 966.6 & 999.0 & 999.0 & 999.0 & 9.0 & \\
\hline 2011 & 11 & 08 & 1 & 50 & 188 & 23.9 & 29.4 & 10.95 & 13.79 & 10.26 & 999 & 965.3 & 999.0 & 999.0 & 99.0 & 9.0 & \\
\hline 2011 & 11 & 08 & 2 & 50 & 207 & 25.8 & 32.0 & 11.72 & 13.79 & 10.71 & 99 & 965.5 & 999.0 & 999.0 & 999.0 & 9.0 & \\
\hline 2011 & 11 & 08 & 3 & 50 & 212 & 28.5 & 7.1 & 10.67 & 3.79 & 10.02 & 99 & 970.6 & 999.0 & 99.0 & 99.0 & 9.0 & \\
\hline 2011 & 11 & 09 & 0 & 50 & 222 & 27.6 & 35.9 & 12.07 & 13.79 & 10.69 & 99 & 972.9 & 999.0 & 99.0 & 0 & 9.0 & \\
\hline 2011 & 11 & 09 & 01 & 50 & 219 & 26.1 & 33.3 & 11.09 & 13.79 & 10.30 & 99 & 976.9 & 999.0 & 999.0 & 999.0 & 9.0 & \\
\hline 2011 & 11 & 09 & 2 & 50 & 217 & 25.1 & 31.9 & 12.14 & 14.81 & 11.29 & 99 & 980.2 & 999.0 & 999.0 & .0 & 9.0 & \\
\hline 2011 & 11 & 09 & 03 & 50 & 215 & 23.9 & 30.4 & 10.68 & 13.79 & 10.82 & 99 & 983.0 & 999.0 & 999.0 & 999.0 & 99.0 & \\
\hline 2011 & 11 & 09 & 04 & 50 & 221 & 22.7 & 29.9 & 11.84 & 16.00 & 11.59 & 99 & 985.4 & 999.0 & 999.0 & 999.0 & 9.0 & \\
\hline 2011 & 11 & 09 & 05 & 50 & 218 & 20.8 & 26.9 & 10.63 & 16.00 & 10.83 & 9 & 987.5 & & & & 0 & \\
\hline 2011 & 11 & 09 & 06 & 50 & 218 & 20.1 & 26.4 & 10.25 & & 11.11 & 9 & 989.7 & & & & 0 & \\
\hline 2011 & 11 & 09 & 07 & 50 & 218 & 18.7 & 23.3 & 10.92 & 14.81 & 10.98 & 999 & 991.0 & 999.0 & 999.0 & 999.0 & 99.0 & 99 \\
\hline 2011 & 11 & 09 & 08 & 50 & 218 & 16.4 & 20.6 & 10.39 & 12.90 & 10.75 & 999 & 991.5 & 999.0 & 999.0 & 999.0 & 99.0 & 99. \\
\hline 2011 & 11 & 09 & 09 & 50 & 212 & 17.2 & 21.5 & 8.46 & 13.79 & 9.87 & 999 & 991.3 & 999.0 & 999.0 & 999.0 & 99.0 & 99. \\
\hline 2011 & 11 & 09 & 10 & 50 & 225 & 18.7 & 22.5 & 9.11 & 13.79 & 10.01 & 999 & 991.4 & 999.0 & 999.0 & & 99.0 & ד. \\
\hline 2011 & 11 & 09 & 11 & 50 & 228 & 16.6 & 19.8 & 9.33 & 13.79 & 9.83 & 999 & 991.2 & 999.0 & 999.0 & 999.0 & 99.0 & 99. \\
\hline 2011 & 11 & 09 & 12 & 50 & 228 & 19.7 & 25.1 & 8.74 & 12.90 & 9.51 & 999 & 991.0 & 999.0 & 999.0 & & 9.0 & \\
\hline 011 & 11 & 09 & 13 & 50 & 216 & 18.3 & 23.0 & 8.10 & 12.12 & 9.17 & 999 & 990.6 & 999.0 & 999.0 & & 99.0 & \\
\hline 011 & 11 & 09 & 14 & 50 & 208 & 15.7 & 18.8 & 7.19 & 12.12 & 8.83 & 999 & 989.4 & 999.0 & 999.0 & 999.0 & 99.0 & 99 \\
\hline
\end{tabular}

Relevant NOAA measurement descriptions:

WVHT: "Significant wave height (meters) is calculated as the average of the highest one-third of all of the wave heights during the 20 -minute sampling period."

DPD: "Dominant wave period (seconds) is the period with the maximum wave energy."

Estimate of maximum wave setup conditions based on open ocean storm conditions:

Calculation of deep-water wave length $\left(L_{\infty}\right)$ using standard linear airy-wave theory equations for deep-water waves:

$$
L_{\infty}=\frac{g T^{2}}{2 \pi} \quad \text { where wave period }(\mathrm{T})=14.81 \text { seconds } \quad L_{\infty}=342 \mathrm{~m}
$$

Based on an observed typical Norton Sound region beach slope (S) of 5:100, the dimensionless deep-water Iribarren number $\left(\xi_{\infty}\right)$ under the above conditions would be:

$$
\xi_{\infty}=\frac{S}{\sqrt{H_{\infty} / L_{\infty}}} \quad \text { where } H_{\infty}=12.14 \mathrm{~m} \quad \xi_{\infty}=0.27
$$

Using the empirical relationship between deep-water significant wave height, the Iribarren number, and the maximum setup height at the shoreline $\left(\bar{\eta}_{\text {max }}\right)$ identified by Holman and Sallenger $(1985)^{1}$, we can estimate an expected value for these storm conditions:

$$
\bar{\eta}_{\text {max }}=0.45 \xi_{\infty} H_{\infty} \quad \bar{\eta}_{\text {max }}=1.5 \mathrm{~m}
$$

'Tolman, R.A., and Sallenger, A.H., 1985, Set-up and swash on a natural beach: Journal of Geophysical Research, v. 90, no. C1, p. 945-953. 